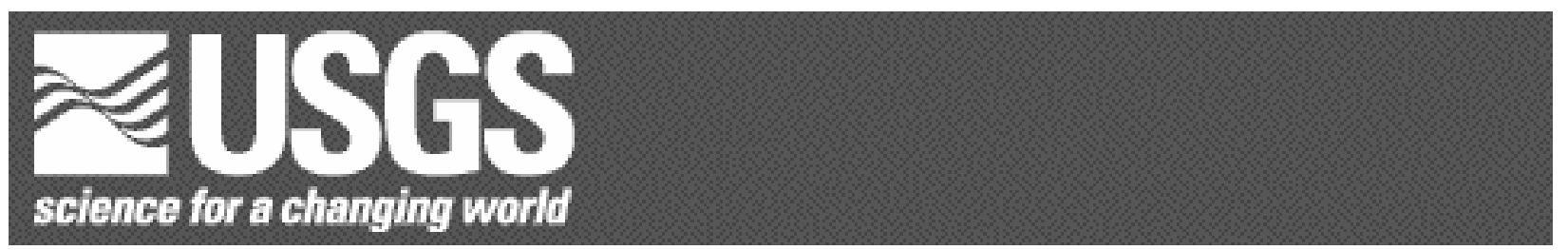

\title{
Catalog of Earthquake Hypocenters at Alaskan Volcanoes: January 1 through December 31, 2005
}

By James P. Dixon ${ }^{1}$, Scott D. Stihler ${ }^{2}$, John A. Power ${ }^{1}$, Guy Tytgat ${ }^{2}$, Steve Estes $^{2}$, and Stephen R. McNutt ${ }^{2}$

Open-File Report 2006-1264

2006

Any use of trade, firm, or product names is for descriptive purposes only and does not imply endorsement by the U.S. Government.

\section{U.S. DEPARTMENT OF THE INTERIOR \\ U.S. GEOLOGICAL SURVEY}

${ }^{1}$ U. S. Geological Survey Alaska Science Center, Alaska Volcano Observatory 4200 University Drive, Anchorage, AK 99508-4667

${ }^{2}$ University of Alaska Fairbanks - Geophysical Institute,

903 Koyukuk Drive, Fairbanks, AK 99775-7320 


\section{CONTENTS}

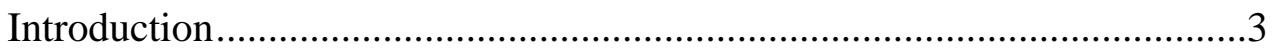

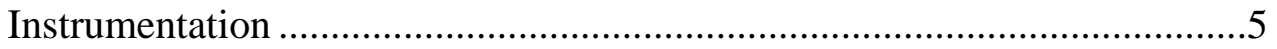

Data Acquisition and Reduction .......................................................

Seismic Velocity Models .......................................................................11

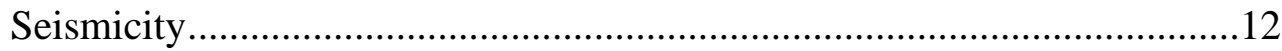

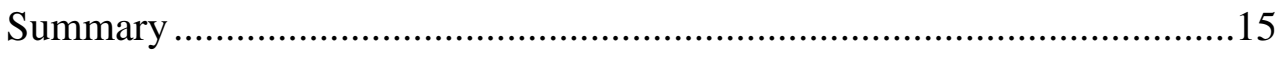

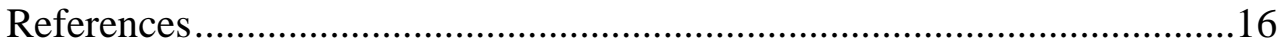

Appendix A: Maps of the earthquakes located in 2005............................18

Appendix B: Parameters for all AVO seismograph stations .....................47

Appendix C: Maps of permanent AVO seismograph stations....................52

Appendix D: Station operational status ............................................66

Appendix E: Seismic Velocity models .................................................71

Appendix F: Maps showing volcanic zones modeled using cylinders .......75

Appendix G: Previous AVO Earthquake Catalogs ...................................77

Appendix H: Selected AVO papers published in 2005 ............................78 


\section{Introduction}

The Alaska Volcano Observatory (AVO), a cooperative program of the U.S. Geological Survey, the Geophysical Institute of the University of Alaska Fairbanks, and the Alaska Division of Geological and Geophysical Surveys, has maintained seismic monitoring networks at historically active volcanoes in Alaska since 1988 (Figure 1). The primary objectives of the seismic program are the real-time seismic monitoring of active, potentially hazardous, Alaskan volcanoes and the investigation of seismic processes associated with active volcanism. This catalog presents calculated earthquake hypocenters and seismic phase arrival data, and details changes in the seismic monitoring program for the period January 1 through December 31, 2005. A list of previous catalogs can be found in Appendix G.

\section{Historically Active Volcanoes in Alaska}

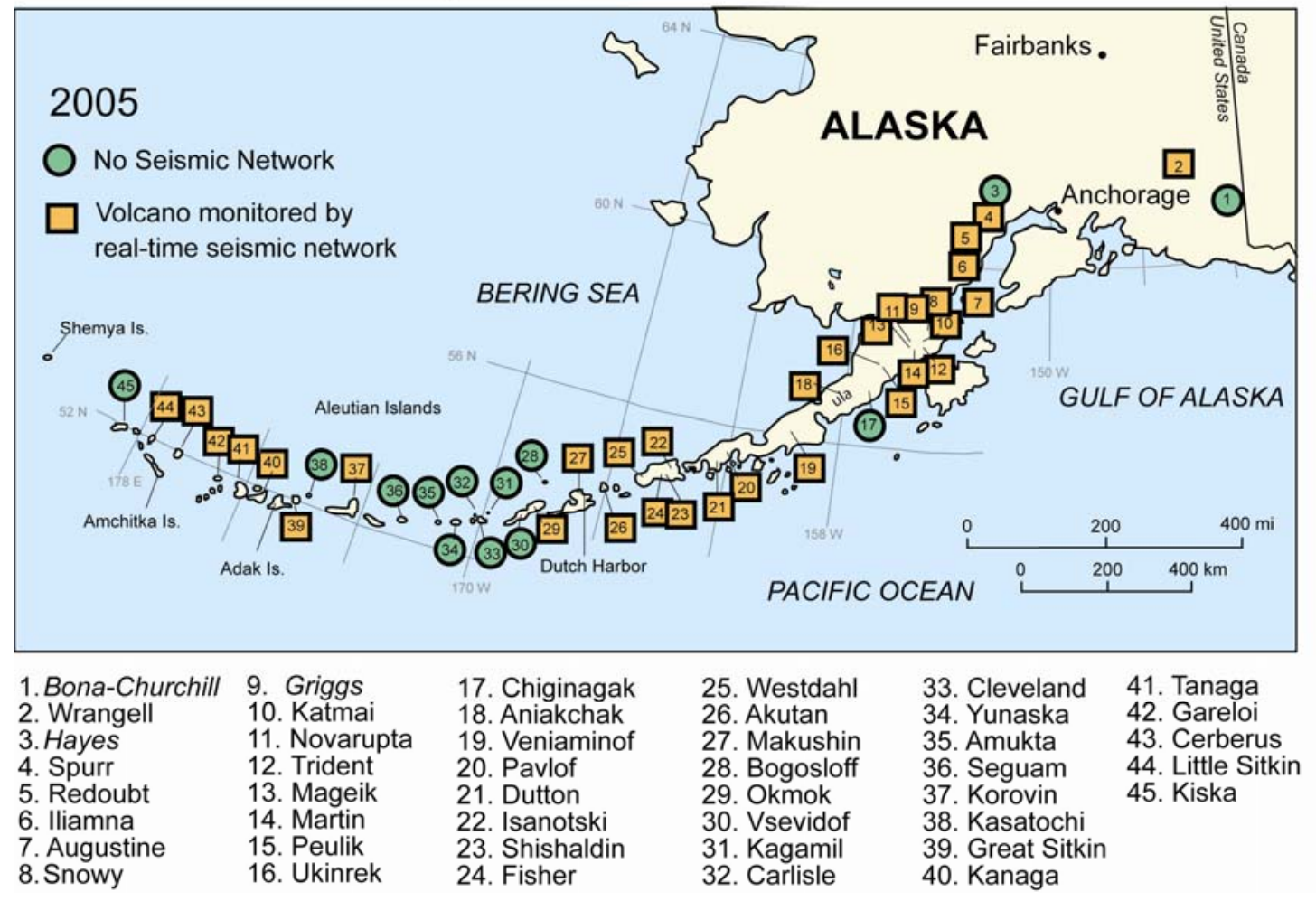

Figure 1. Orange squares show the location of all Alaskan volcanoes seismically instrumented by AVO as of 2005. Volcanoes with no documented historical unrest but still considered hazardous, based on late Holocene eruptive activity are italicized. 
The AVO seismograph network was used to monitor the seismic activity at thirtytwo volcanoes within Alaska in 2005 (Figure 1). The network was augmented by two new subnetworks to monitor the Semisopochnoi Island volcanoes and Little Sitkin Volcano. Seismicity at these volcanoes was still being studied at the end of 2005 and has not yet been added to the list of permanently monitored volcanoes in the AVO weekly update. Following an extended period of monitoring to determine the background seismicity at the Mount Peulik, Ukinrek Maars, and Korovin Volcano, formal monitoring of these volcanoes began in 2005. AVO located 9,012 earthquakes in 2005 (Table 1).

Table 1: Number of earthquakes located per year by AVO for the last ten years.

\begin{tabular}{|c|c|c|}
\hline Year & Earthquakes located per year & Volcanoes with seismograph networks \\
\hline 1996 & 6,466 & 15 \\
\hline 1997 & 2,930 & 17 \\
\hline 1998 & 2,873 & 19 \\
\hline 1999 & 2,769 & 21 \\
\hline 2000 & 1,551 & 21 \\
\hline 2001 & 1,427 & 23 \\
\hline 2002 & 7,242 & 24 \\
\hline 2003 & 3,911 & 27 \\
\hline 2004 & 6,928 & 28 \\
\hline 2005 & 9,012 & 32 \\
\hline
\end{tabular}

Monitoring highlights in 2005 include: (1) seismicity at Mount Spurr remaining above background, starting in February 2004, through the end of the year and into 2006; (2) an increase in seismicity at Augustine Volcano starting in May 2005, and continuing through the end of the year into 2006; (3) volcanic tremor and seismicity related to lowlevel strombolian activity at Mount Veniaminof in January to March and September; and (4) a seismic swarm at Tanaga Volcano in October and November (Table 2).

This catalog includes: (1) descriptions and locations of seismic instrumentation deployed in the field in 2005; (2) a description of earthquake detection, recording, analysis, and data archival systems; (3) a description of seismic velocity models used for earthquake locations; (4) a summary of earthquakes located in 2005; and (5) an accompanying UNIX tar-file with a summary of earthquake origin times, hypocenters, magnitudes, phase arrival 
times, and location quality statistics; daily station usage statistics; and all HYPOELLIPSE (Lahr, 1999) files used to determine the earthquake locations in 2005.

Table 2: Highlights of Alaskan volcanic seismicity in 2005.

\begin{tabular}{|c|c|c|}
\hline Dates & Volcano & Event \\
\hline January -December 2005 & Spurr & Continuing increased seismicity \\
\hline May-December 2005 & Augustine & Increased seismicity \\
\hline Jan-March, and Sept 2005 & Veniaminof & Minor ash bursts recorded in seismic data \\
\hline October-November 2005 & Tanaga & Increased seismicity \\
\hline
\end{tabular}

\section{Instrumentation}

In 2005, the AVO seismograph network was expanded to 187 permanent seismograph stations (Appendix B, C). The AVO seismograph network is composed of 23 subnetworks with 4-20 seismograph stations per subnetwork, and nine regional seismograph stations. Two new subnetworks were installed in September to monitor Mount Cerberus on Semisopochnoi Island and Little Sitkin Volcano. In response to continued increased seismic activity at Mount Spurr, 11 temporary broadband stations were installed in June and removed three months later (Appendix B). Five regional stations (CNP, HOM, NNL, SYI, $\mathrm{XLV}$ ), reported in previous earthquake catalogs, have been removed from the AVO inventory since they were inaccurately listed as AVO stations in the past.

Of the 187 permanent seismograph stations (265 different components) operated by AVO, 150 were short-period vertical-component seismograph stations. All these stations had either Mark Products L4 or Teledyne-Geotech S13 seismometers with a one-second natural period. AVO also operated 23 three-component, short-period instruments during the catalog period. The instruments used at sites with three component sensors were Mark Products L22 seismometers with a 0.5-second period, Mark Products L4-3D seismometers with a one-second period and Teledyne-Geotech S13 seismometers with a one-second natural period. A total of 15 broadband stations were operated with either Guralp CMG40T seismometers (frequency range: $0.102 \mathrm{~Hz}$ to $50 \mathrm{~Hz}$ ) or Guralp CMG-6TD seismometers (frequency range: $0.033 \mathrm{~Hz}$ to $50 \mathrm{~Hz}$ ). 
The majority of the short-period stations were digitized at 100 samples/second (sps). The Semisopochnoi and Little Sitkin subnetworks were recorded at 50 sps due to limitations in the broadband telemetry between the recording hub and Anchorage. Broadband stations were digitized at 50 sps. Typical calibration curves for seismometers used in the AVO seismograph network are shown in Figures 2-6.

Data from short-period seismograph stations were telemetered using voltagecontrolled oscillators (VCOs) to transform the signals generated by the seismometer in response to ground velocity from a voltage to a frequency-modulated carrier suitable for transmission over a radio link or telephone circuit. AVO primarily used McVCO (McChesney, 1999) to modulate signals in the field. In rare cases, other VCO models were used instead of the McVCO but these are being replaced by McVCOs as stations are visited. These signals were transmitted via UHF and VHF radio to communication hubs located in Adak, Akutan, Amchitka Island, Anchorage, Cold Bay, Dutch Harbor, Homer, Kenai, King Cove, King Salmon, Port Heiden, Sourdough, and Tolsona. Data were then digitized at the Adak, Amchitka Island, Dutch Harbor, Homer, Kenai and King Salmon communication

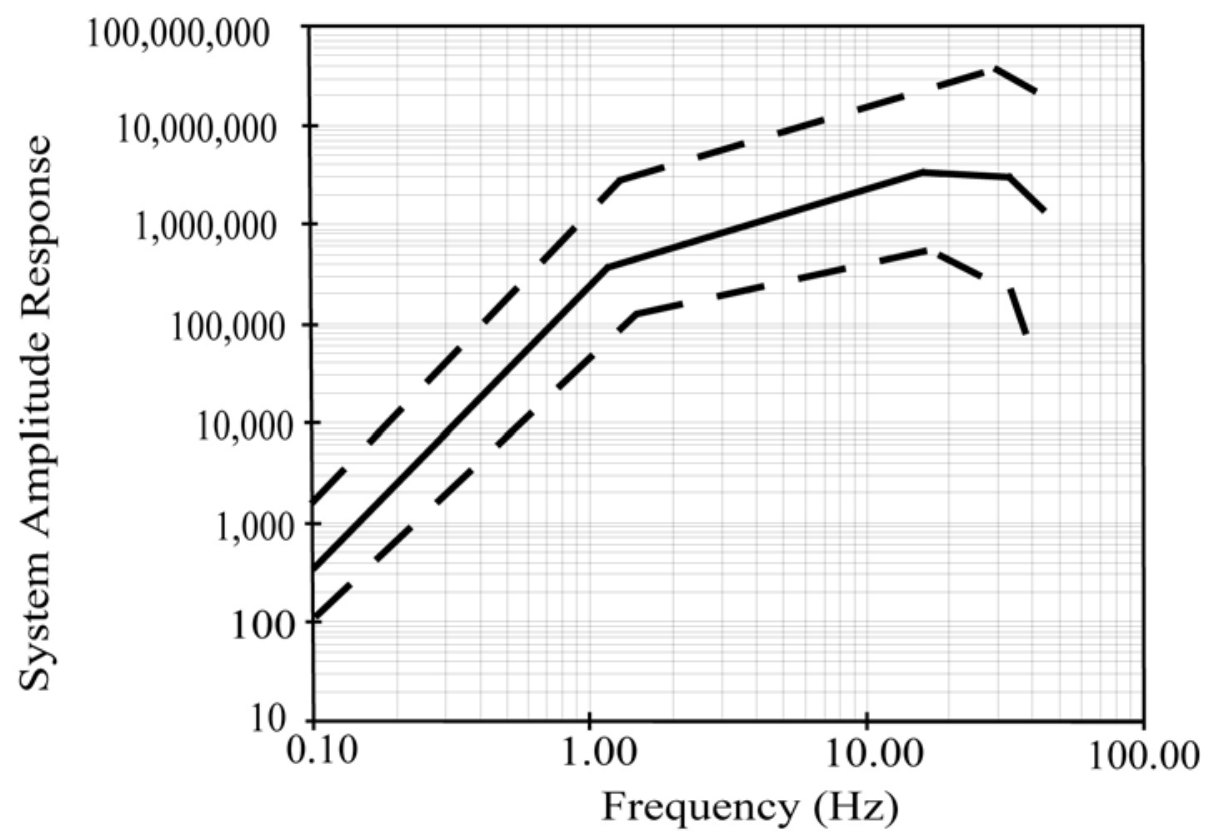

Figure 2. Representative displacement response curves for the 138 short-period stations using a Mark Products L4 or L4-3D seismometer. The solid line illustrates the typical calibration curve and the dashed lines show the range of calibration curves for all AVO stations using an L4 or L4-3D seismometer. 


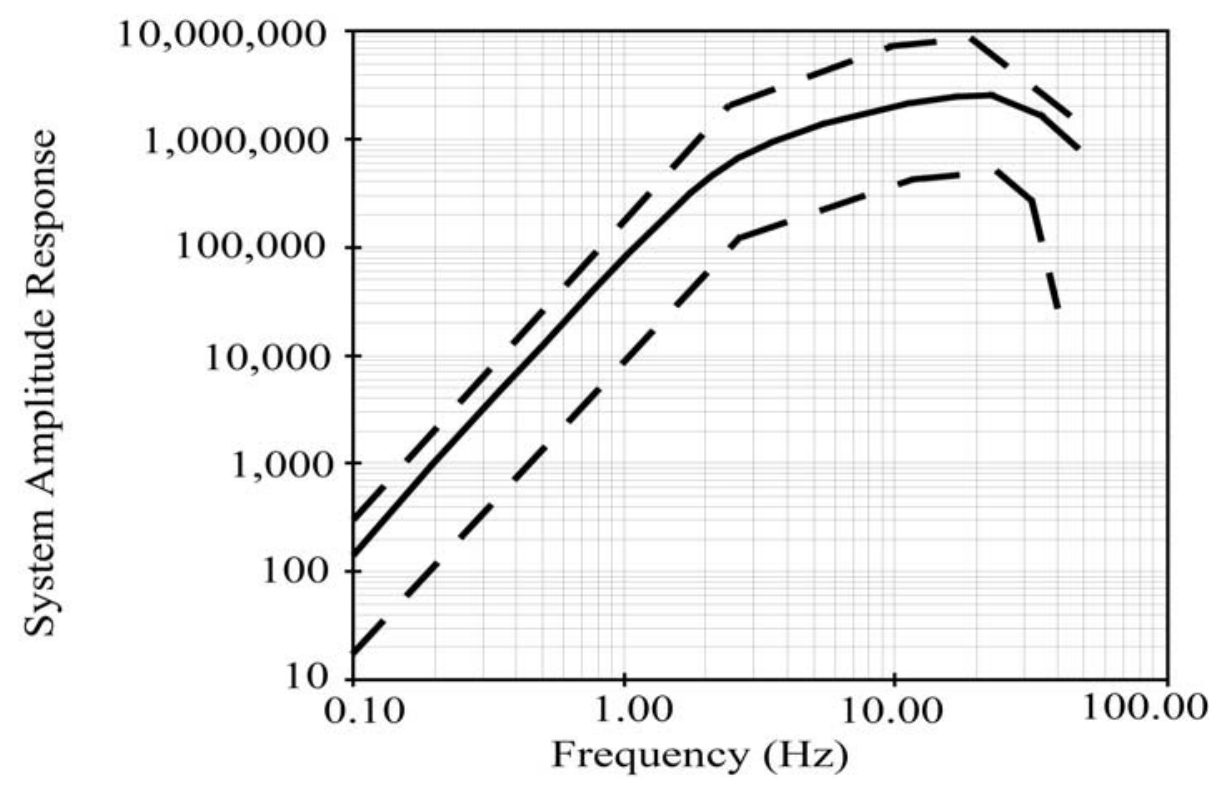

Figure 3. Representative displacement response curves for the 17 short-period stations using a Mark Products L22 seismometer. The solid line illustrates the typical calibration curve and the dashed lines show the range of calibration curves for all AVO stations using an L22 seismometer.

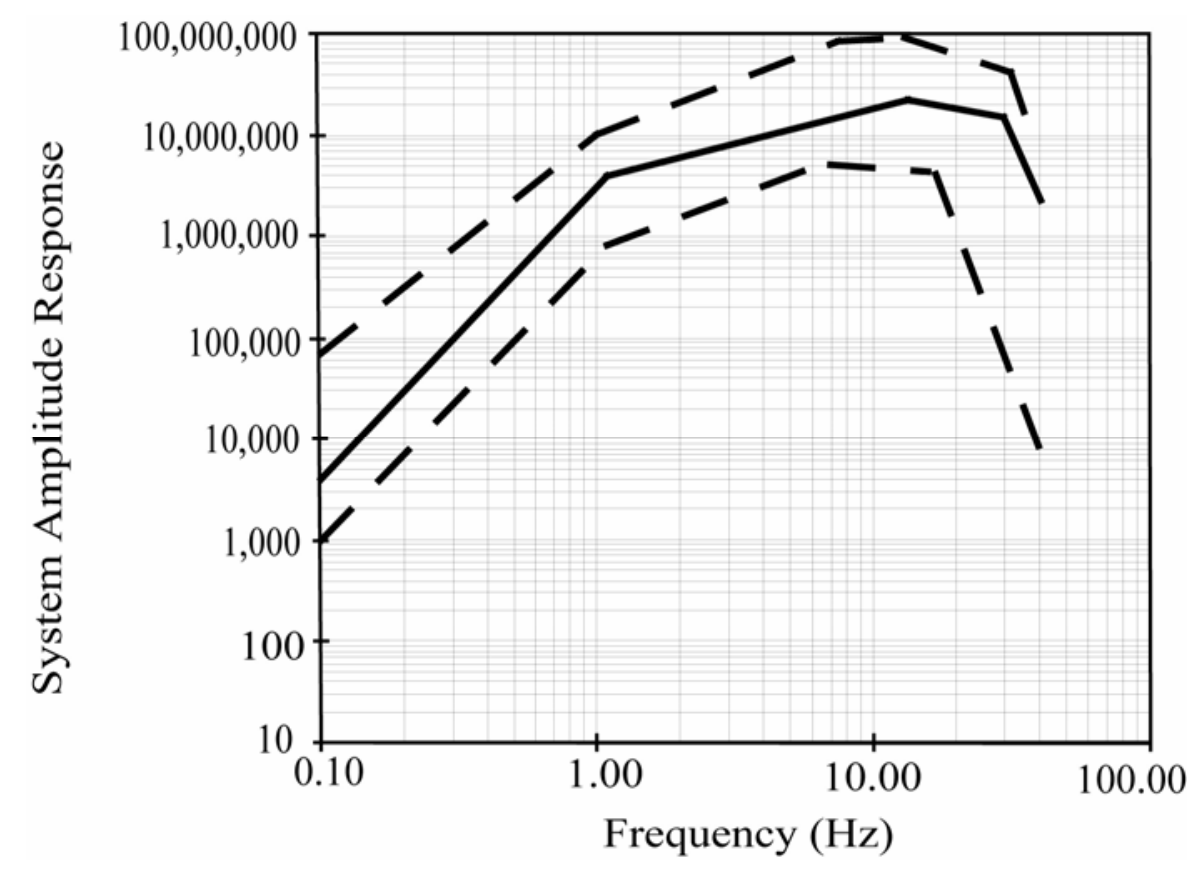

Figure 4. Representative displacement response curves for the 16 short-period stations using a Teledyne-Geotech S13 seismometer. The solid line illustrates the typical calibration curve and the dashed lines show the range of calibration curves for all AVO stations using an S13 seismometer. 


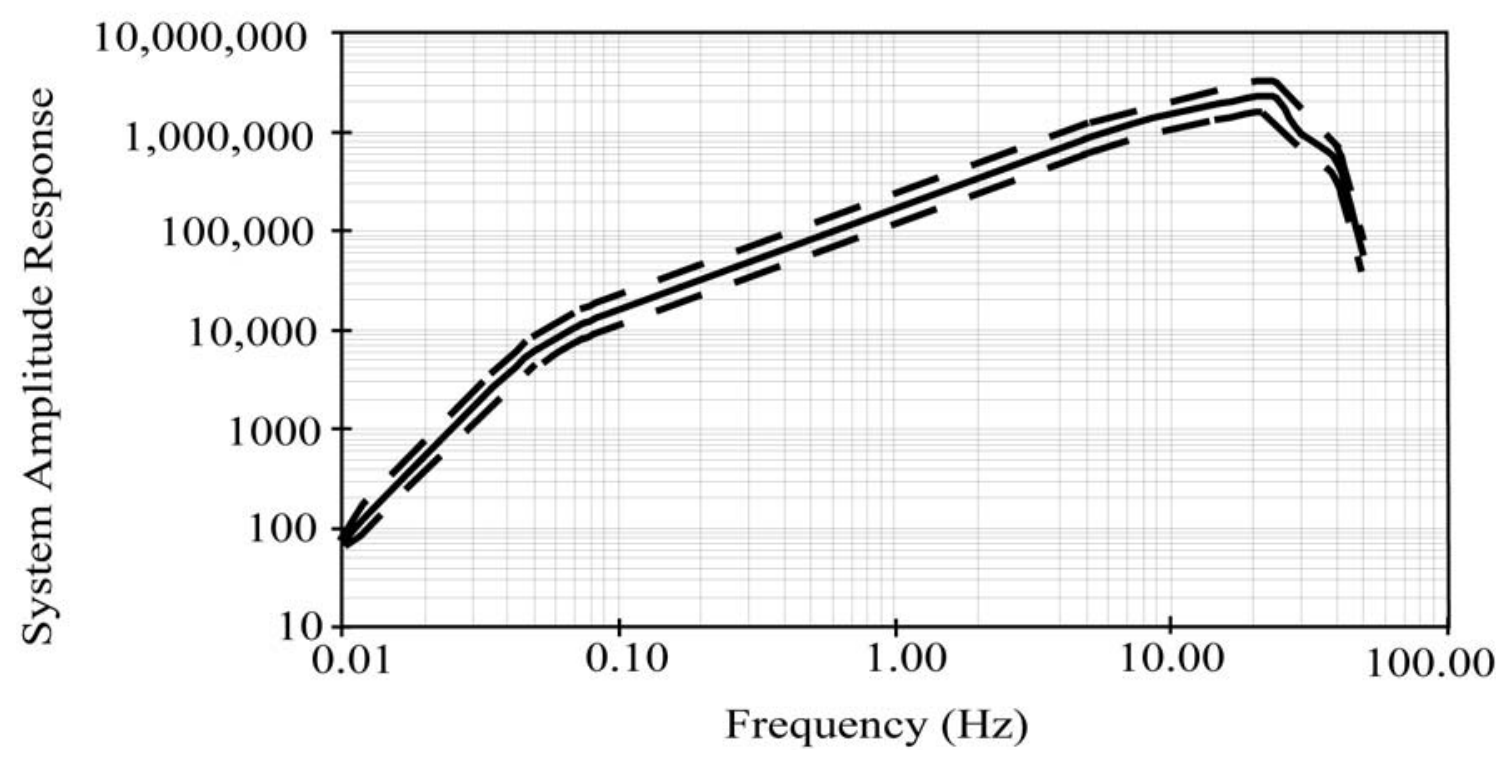

Figure 5. Representative displacement response curves for the two broadband stations using a Guralp CMG-40T seismometer. The solid line illustrates the typical calibration curve and the dashed lines show the range of calibration curves for all AVO stations using a Guralp CMG-40T seismometer.

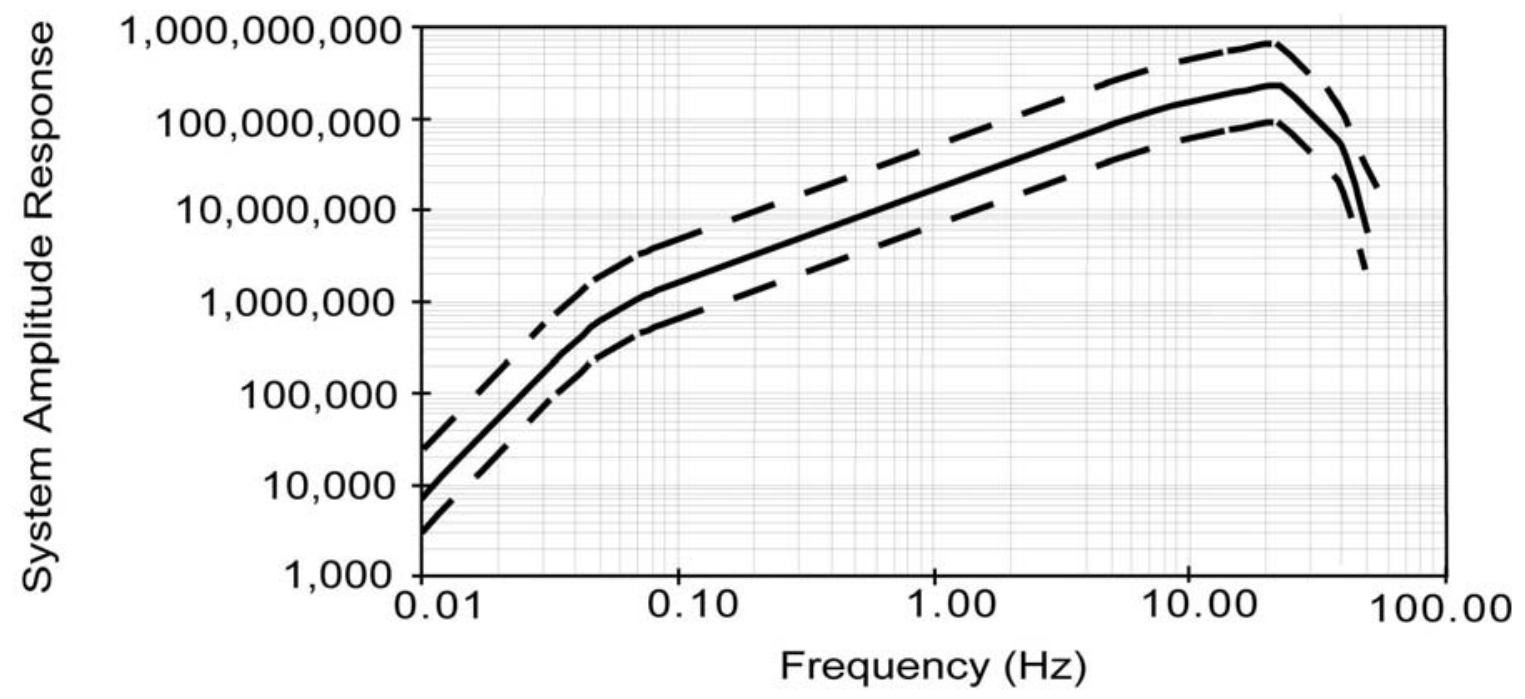

Figure 6. Representative displacement response curves for the 24 broadband stations using a Guralp CMG-6TD seismometer. The solid line illustrates the typical calibration curve and the dashed lines show the range of calibration curves for all AVO stations using a Guralp CMG-6TD seismometer. 
hubs and directed to AVO offices via high speed digital circuits. From all other hubs, signals were relayed via leased telephone circuits to AVO offices in Anchorage and Fairbanks where the signals were digitized. Data from broadband seismograph stations were digitized at the seismograph station site and transmitted digitally using spread-spectrum radios to communication hubs in Akutan, Anchorage, Dutch Harbor, Homer, and King Salmon. These data were forwarded to AVO offices in Fairbanks and Anchorage via leased telephone circuits.

Locations and descriptions for all AVO stations operated during 2005 are contained in Appendix B. Maps showing the locations of permanent stations with respect to individual volcanoes are contained in Appendix C. Estimates of each station's operational status for the catalog period are shown in Appendix D. Other station information, such as calibration information contained in the file CALDATA.PRM, is available within the associated compressed UNIX tar-file.

\section{Data Acquisition and Reduction}

Data acquisition for the AVO seismograph network was accomplished with duplicate EARTHWORM systems (Johnson, 1995) located at AVO offices in Anchorage and Fairbanks, providing a backup in case of failure at either location. Data were recorded in continuous and event detected modes. Event detected data were collected using the EARTHWORM modules, 'Carlstatrig' and 'Carlsubtrig'. The 'Carlstatrig’ parameters were set as follows: Long-term-average (LTA) time $=8$ seconds, Ratio $=2.3$, and Quiet $=4$. 'Carlsubtrig' was modified such that a two-letter code was appended to the filename of each trigger to identify which subnetwork triggered or if the event was a regional trigger. If four or more subnetworks triggered on the same event, all data were saved in a single trigger. These network codes are summarized in Table 3. All data are saved in Seismic Analysis Code (SAC) (Goldstein and others, 1999) format.

Event triggers were processed daily using the interactive seismic data analysis program XPICK (Robinson, 1990), and the earthquake location program HYPOELLIPSE (Lahr, 1999). Each event trigger was visually inspected and false triggers were deleted. 
Table 3: Volcano Subnetwork Designators

\begin{tabular}{|c|c|}
\hline Volcano Subnetwork & Network Code \\
\hline Akutan & $\mathrm{ak}$ \\
\hline Aniakchak & an \\
\hline Augustine & au \\
\hline Semisopochnoi & се \\
\hline Dutton & $\mathrm{dt}$ \\
\hline Iliamna & il \\
\hline Gareloi & ga \\
\hline Great Sitkin & gs \\
\hline Kanaga & ki \\
\hline Katmai & $\mathrm{ka}$ \\
\hline Volcano & ko \\
\hline Little Sitkin & ls \\
\hline Makushin & $\mathrm{ma}$ \\
\hline Okmok & ok \\
\hline Pavlof & pv \\
\hline Peulik & pl \\
\hline Redoubt & rd \\
\hline Regional Event & $\mathrm{rg}$ \\
\hline Shishaldin & sh \\
\hline Spurr & sp \\
\hline Tanaga & ta \\
\hline Veniaminof & vn \\
\hline Westdahl & we \\
\hline Wrangell & wa \\
\hline
\end{tabular}

Each subsequent event was identified by a classification code (Table 4) and stored as a comment in the event location pick file. This classification system was modeled after that described by Lahr and others (1994). Earthquakes with a P and S-wave separation of greater than five seconds on the closest station were assumed to come from non-volcanic sources and were typically discarded. Each hypocenter was checked using a computer algorithm that identified events that did not meet the following minimum parameters: three P-phases, two S-phases, and standard hypocentral errors less than $15 \mathrm{~km}$. If upon revaluation, the minimum parameters could not be met, the event was removed from the final catalog listing. For all the 2005 earthquakes in the AVO catalog, the average rootmean-square travel-time error was 0.126 seconds. 
Table 4: Classification codes

\begin{tabular}{|c|c|}
\hline Event Classification & Classification Code \\
\hline Volcano-Tectonic (VT) & $\mathrm{a}$ \\
\hline Low-Frequency (LF) & $\mathrm{b}$ \\
\hline Hybrid & $\mathrm{h}$ \\
\hline Regional-Tectonic & $\mathrm{E}$ \\
\hline Teleseismic & $\mathrm{T}$ \\
\hline Shore-Ice & $\mathrm{i}$ \\
\hline Calibrations & $\mathrm{C}$ \\
\hline Other non-seismic & $\mathrm{o}$ \\
\hline Cause unknown & $\mathrm{x}$ \\
\hline
\end{tabular}

\section{Seismic Velocity Models}

During 2005, AVO employed 11 local seismic velocity models and one regional seismic velocity model (Appendix E) to locate earthquakes at monitored volcanoes. All velocity models were one-dimensional models utilizing horizontal layers to approximate the local seismic velocity structures. Each model, with one exception, assumed a series of constant velocity layers. The single exception was the Akutan velocity model (Power and others, 1996), which had a velocity gradient in the top layer overlying a half-space of constant velocity.

One or more vertical cylinders were used to model the volcanic source zones on all volcanoes where a local volcano-specific velocity model was used. Earthquakes within these cylindrical volumes were located with a local model and earthquakes outside of the cylindrical volumes were located with the regional model. All cylindrical volumes had a radius of $20 \mathrm{~km}$ with the exception of the cylinders centered on Shishaldin Volcano and Mount Veniaminof. The cylinder centered on Shishaldin Volcano had a radius of $30 \mathrm{~km}$ in order to encompass Isanotski Peaks. The cylinder centered on Mount Veniaminof also had a radius of $30 \mathrm{~km}$ because of the large size of the volcanic edifice. The top of each cylinder is set at three $\mathrm{km}$ above sea level and the bottom is set at a depth of $50 \mathrm{~km}$ with respect to sea level.

The Akutan, Augustine (Power, 1988), Iliamna (Roman and others, 2001), Tanaga (Power, personal communication, 2005), Veniaminof (Sánchez, 2005) and Westdahl (Dixon, 2005) velocity models were used to locate hypocenters that fell within cylindrical 
volumes described above, centered on each respective volcano. The Cold Bay velocity model (McNutt and Jacob, 1986) was used to locate earthquakes that fell within single cylindrical volumes centered on Mount Dutton and Pavlof Volcano. Earthquakes on Fisher Caldera, Isanotski Peaks, and Shishaldin Volcano that fell within the cylindrical regions centered on Shishaldin Volcano were also located using the Cold Bay velocity model. Five overlapping cylinders defined the area in which the Spurr velocity model (Jolly and others, 1994) was used, four overlapping cylinders defined the area in which the Redoubt velocity model (Lahr and others, 1994) was used, and four overlapping cylinders defined the area in which the Katmai model (Searcy, 2003) was used. The Andreanof velocity model (Toth and Kisslinger, 1984) was used to locate earthquakes within a volume defined by three cylinders centered on Kanaga Volcano, Mount Moffet, and Great Sitkin Volcano. Specific velocity models for Aniakchak Crater, Mount Gareloi, Korovin Volcano, Makushin Volcano, Okmok Volcano, Mount Peulik, and Mount Wrangell were not available in 2005 and the regional velocity model (Fogleman and others, 1993) was used to locate earthquakes near these volcanoes. The cylindrical model parameters, regional velocity model, and volcano-specific models used to locate earthquakes in this report are summarized in Appendix E. Figures showing the volcanic source zones modeled by multiple cylinders are shown in Appendix F.

\section{Seismicity}

The 9,012 earthquakes located in 2005 represent the highest annual total determined by AVO in the last ten calendar years and an increase from the 6,928 earthquakes located in 2004 (Dixon, 2005). Of the earthquakes located in the last two years, a total of 6,105 earthquakes in 2004 and 8,146 earthquakes in 2005 were located within $20 \mathrm{~km}$ of an active volcanic center. The numbers of located events at volcanic centers in the last two years, by seismograph subnetwork, are shown in Table 5.

Using the 2005 earthquake catalog, the magnitude of completeness (Mc) for each subnetwork was calculated (Table 5). The Mc is the lowest magnitude at which we are reasonably certain that all events with a magnitude greater than or equal to the Mc were detected. The Mc was determined using a maximum likelihood estimate of the inflection 
point in the frequency magnitude distribution using the seismology analysis software ZMAP (Weimer, 2001).

Four volcanoes, Mount Spurr, Augustine Volcano, Mount Veniaminof and Tanaga Volcano, showed significant unrest in 2005 and the level of concern color code for each was raised above green. Of these volcanic centers, Mount Veniaminof and Mount Spurr did not have an increased level of activity compared to the seismicity in 2004. At Mount

Table 5: Number of earthquakes located for each seismograph subnetwork in 2004 and 2005 within $20 \mathrm{~km}$ of the volcanic centers in each subnetwork. The totals for 2005 are broken into three event types: volcanic-tectonic (VT), low-frequency (LF) and other (all other possible event types shown in Table 4). Magnitude of completeness (Mc) for AVO seismograph subnetworks used the 2005 catalog. The Semisopochnoi, Dutton, Little Sitkin subnetworks were not included because there were too few earthquakes in 2005 to calculate a Mc.

\begin{tabular}{|c|c|c|c|c|c|c|}
\hline $\begin{array}{c}\text { Volcano } \\
\text { Subnetwork }\end{array}$ & $\begin{array}{c}\text { Earthquakes } \\
\text { located in 2004 }\end{array}$ & $\begin{array}{c}\text { Earthquakes } \\
\text { located in 2005 }\end{array}$ & $\begin{array}{c}\mathbf{2 0 0 5} \\
\text { VT }\end{array}$ & $\begin{array}{c}\mathbf{2 0 0 5} \\
\text { LF }\end{array}$ & $\begin{array}{c}\mathbf{2 0 0 5} \\
\text { Other }\end{array}$ & $\begin{array}{c}\mathbf{2 0 0 5} \\
\text { Mc }\end{array}$ \\
\hline Akutan & 120 & 100 & 99 & 1 & 0 & 0.3 \\
\hline Aniakchak & 5 & 33 & 4 & 29 & 0 & 1.0 \\
\hline Augustine & 241 & 1,204 & 1,180 & 11 & 13 & -0.9 \\
\hline Semisopochnoi & n/a & 6 & 6 & 0 & 0 & n/a \\
\hline Dutton & 40 & 13 & 13 & 0 & 0 & n/a \\
\hline Gareloi & 376 & 580 & 61 & 519 & 0 & 1.0 \\
\hline Great Sitkin & 65 & 51 & 50 & 1 & 0 & 0.3 \\
\hline Iliamna & 805 & 979 & 920 & 59 & 0 & -0.4 \\
\hline Kanaga & 32 & 42 & 42 & 0 & 0 & 0.9 \\
\hline Katmai Cluster & 976 & 1,084 & 1,072 & 11 & 1 & 0.6 \\
\hline Korovin & n/a & 74 & 74 & 5 & 0 & 0.7 \\
\hline Little Sitkin & $\mathrm{n} / \mathrm{a}$ & 15 & 15 & 0 & 0 & n/a \\
\hline Makushin & 233 & 135 & 133 & 2 & 0 & 0.6 \\
\hline Okmok & 44 & 71 & 66 & 5 & 0 & 0.9 \\
\hline Pavlof & 58 & 32 & 14 & 18 & 0 & 1.5 \\
\hline Peulik & 5 & 48 & 47 & 1 & 0 & 0.8 \\
\hline Redoubt & 94 & 70 & 68 & 2 & 0 & 0.1 \\
\hline Shishaldin & 98 & 208 & 11 & 197 & 0 & 0.9 \\
\hline Spurr & 2,616 & 2,317 & 1,980 & 320 & 17 & 0.2 \\
\hline Tanaga & 11 & 925 & 920 & 4 & 1 & 1.0 \\
\hline Veniaminof & 21 & 24 & 24 & 0 & 0 & 1.1 \\
\hline Westdahl & 166 & 27 & 24 & 3 & 0 & 0.9 \\
\hline Wrangell & 99 & 106 & 15 & 91 & 0 & 0.7 \\
\hline Totals & 6,105 & 8,146 & 6,833 & 1,279 & 34 & 0.7 \\
\hline
\end{tabular}


Veniaminof, the seismic activity is dominated by non-locatable tremor and low-frequency events. The seismicity in 2005 at Mount Spurr is similar to that in 2004 (Power, 2004) because the volcanic unrest started in mid 2004 and continued through 2005. At Augustine Volcano an increase in the seismicity above background was first noted in May 2005. By the end of 2005 the seismicity was well above background due to an episode of unrest continuing into 2006. The majority of the seismicity at Tanaga Volcano occurred in October and November 2005. By the end of 2005, the level of seismicity at Tanaga Volcano had returned to background levels.

The subnetworks at Iliamna and Aniakchak showed increased seismic activity. The number of earthquakes was elevated for Iliamna compared to background for the first half of 2005 but remained at background for the last part of 2005. At Aniakchak Crater, there were three small burst of activity (one in January, two in December) accounting for the increased seismicity at this volcanic center. The seismicity at Shishaldin Volcano and Mount Gareloi also increased from that in 2004. The seismicity at both volcanic centers is dominated by low-frequency events that are near the limits of detection. Small changes in factors like background noise or volcanic activity can cause widely varying apparent seismicity rates.

The seismicity in the Katmai volcanic cluster for 2005 was similar to that in 2004. Several volcanic centers (Trident Volcano, Mount Katmai and Mount Martin) showed elevated seismic activity at times in 2005. The seismicity at Trident Volcano was consistently higher than normal through most of 2005. Declines in seismicity were noted at Novarupta, Mount Martin and Mount Mageik in regular AVO staff reports. Novarupta was the only volcanic center that consistently showed lower levels of seismicity in 2005. Seismicity rates at the Wrangell, Redoubt, Pavlof, Akutan, Okmok, Kanaga, and Great Sitkin subnetworks, were also similar to that in 2004.

Seismicity at Mount Dutton, Makushin Volcano and Westdahl Peak in 2005 declined compared to that in 2004. Near Mount Dutton, the rate of seismicity is low but highly variable. No station outages are responsible for the apparent decrease in seismicity. The decrease in seismicity at Makushin Volcano is related in part to several long-lived station outages lasting six months or longer. The seismicity at Westdahl Peak would show 
no change to the previous year if a cluster of activity in January 2004 is removed from the earthquake totals.

The subnetwork at Mount Peulik was installed in mid-2004 and the subnetworks at Korovin, Semisopochnoi and Little Sitkin were established in 2005. No comparisons could be made for these four subnetworks.

\section{Summary}

Between January 1 and December 31, 2005, AVO located 9,012 earthquakes of which 8,146 occurred at or near volcanoes in Alaska. Monitoring highlights in 2005 include: elevated seismicity and low level tremor at Mount Veniaminof, and an increase in seismicity at Mount Spurr, Augustine Volcano and Tanaga Volcano, all related to episodes of volcanic unrest. New seismic subnetworks were installed on Semisopochnoi Island and Little Sitkin Volcano.

Available for download with this report is a compressed Unix tar-file containing a summary listing of earthquake hypocenters and all the necessary HYPOELLIPSE input files to recalculate the hypocenters including station locations and calibrations, seismic velocity models, and phase information. The reader should refer to Lahr (1999) for information on file formats and instructions for configuring and running the location program HYPOELLIPSE. Archives of waveform data are maintained on DVD-ROM at AVO offices in Fairbanks and Anchorage.

\section{Acknowledgements}

The contents of this report reflect a great deal of hard work by a large number of people including AVO, AEIC, and USGS personnel and various students, interns and volunteers. We thank Silvio DeAngelis and Mike Thorne for formal reviews of the text and figures. 


\section{References}

Dixon, J. P., J. A. Power, and S. D. Stihler (2005). Seismic Observations of Westdahl volcano and Western Unimak Island Alaska: 1999-2005, Eos Trans. AGU, 86, no. 52, Fall Meeting Suppl. Abstract S11b-0169.

Fogleman, K. A., J. C. Lahr, C. D. Stephens, and R. A. Page (1993). Earthquake locations determined by the southern Alaska seismograph network for October 1971 through May 1989, U.S. Geol. Surv. Open-File Rept. 93-309, 54 p.

Goldstein, P., D. Dodge, and M. Firpo (1999). SAC2000: Signal processing and analysis tools for seismologists and engineers, in International Handbook of Engineers and Engineering Seismology, Lee W.H.K , Kanamori, H., Jennings, P.P, Kisslinger, C. (Editors), v. 81B, Academic Press, San Diego, CA, 1613-1614.

Johnson, C. E., A. Bittenbinder, D. Bogaert, L. Dietz, and W. Kohler (1995). EARTHWORM: A Flexible Approach to Seismograph network Processing, IRIS Newsletter, 14, no. 2, 1-4.

Jolly, A. D., R. A. Page, and J. A. Power (1994). Seismicity and stress in the vicinity of Mt. Spurr volcano, south-central Alaska, J. Geophys. Res., 99, 15305-15318.

Lahr, J. C, B. A. Chouet, C. D. Stephens, J. A. Power, and R. A. Page (1994). Earthquake classification, location, and error analysis in a volcanic environment: Implications for the magmatic system of the 1989-90 eruptions at Redoubt Volcano, Alaska, J. Volc. Geotherm. Res., 62, 137-152.

Lahr, J. C. (1999). HYPOELLIPSE: A Computer Program for Determining Local Earthquake Hypocentral Parameters, Magnitude, and First Motion Pattern, U.S. Geol. Surv. Open-File Rept. 99-23, 116 pp.

McChesney, P. J. (1999). McVCO Handbook 1999, U.S. Geol. Surv. Open-File Rept. 99361, $48 \mathrm{p}$.

McNutt, S. R., and K. H. Jacob (1986). Determination of large-scale velocity structure of the crust and upper mantle in the vicinity of Pavlof volcano, Alaska: J. of Geophys. Res., 91, 5013-5022.

Power, J. A. (1988). Seismicity associated with the 1986 eruption of Augustine Volcano, Alaska, Masters Thesis, University of Alaska Fairbanks, 149 p.

Power, J. A., J. F. Paskievitch, D. H. Richter, R. G. McGimsey, P. Stelling, A. D. Jolly, and H. J. Fletcher (1996). 1996 seismicity and ground deformation at Akutan Volcano, Eos Trans. AGU, 77, F514. 
Power, J. A. (2004). Renewed unrest at Mount Spurr Volcano, Alaska, Eos Trans. AGU, 85, 434.

Robinson, M. (1990). XPICK users manual, version 2.7: Seismology Lab, Geophysical Institute, University of Alaska Fairbanks, 93 p.

Rogers, J. A., S. Maslak, and J. C. Lahr (1980). A seismic electronic system with automatic calibration and crystal reference, U.S. Geol. Surv. Open-File Rept. 80-324, 130 p.

Roman, D. C., J. A. Power, S. C. Moran, K. V. Cashman, S. D. Stihler (2001). Unrest at Iliamna Volcano, Alaska in 1996, Evidence for a magmatic intrusion, Eos Trans. AGU, v. 82, F1329.

Sánchez, J. J. (2005). Volcano Seismology from around the World: Case Studies from Mount Pinatubo (Philippines), Galeras (Columbia), Mount Wrangell and Mount Veniaminof (Alaska), Ph.D. Dissertation, University of Alaska Fairbanks, 208 p.

Searcy, C. K. (2003). Station Corrections for the Katmai Region Seismograph network, U.S. Geol. Surv. Open-File Rept. 03-403, 16 p.

Toth, T., and C. Kisslinger (1984). Revised focal depths and velocity model for local earthquakes in the Adak seismic zone, Bull. Seism. Soc. Am., 74, 1349-1360.

Wiemer, S. (2001). A software package to analyze seismicity: ZMAP, Seism. Res. Lett., 72, 373-382. 
Appendix A: Maps showing the locations of the earthquakes located in 2005.

Wrangell Volcano Seismicity

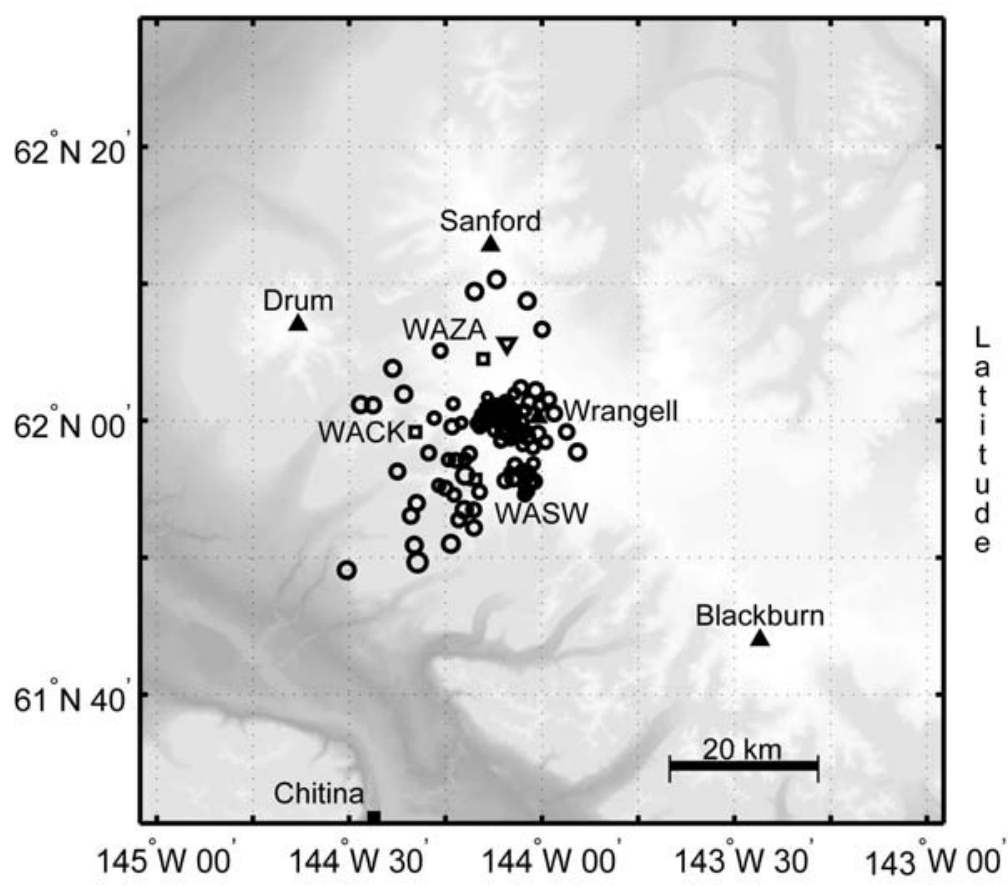

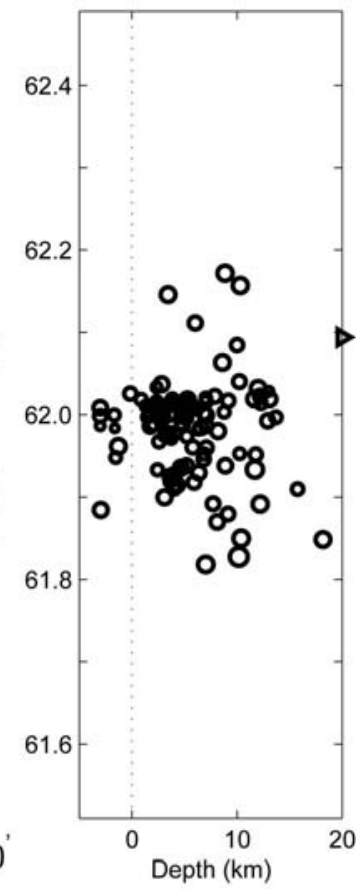

Mag. Symb. Size

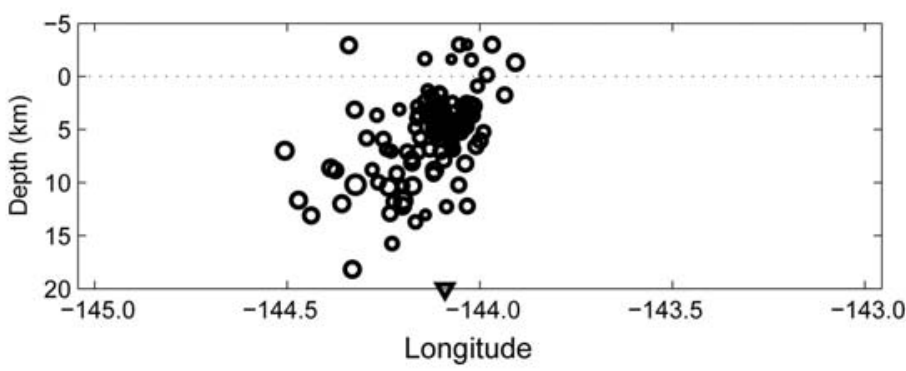

$\begin{array}{ll}0 & 0 \\ 1 & \circ \\ 2 & \circ \\ 3 & 0 \\ 4 & \bigcirc \\ 5 & O\end{array}$

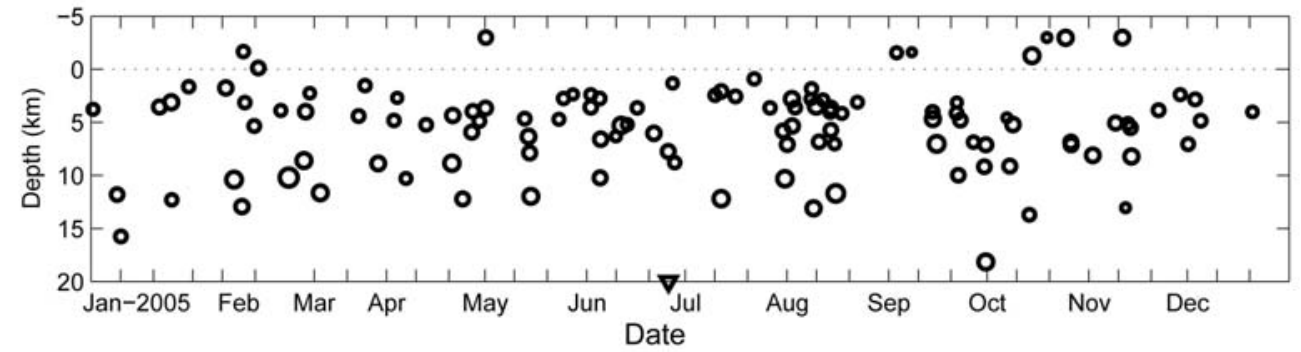

Figure A1. Summary plots of 116 earthquakes located near Mount Wrangell in 2005. Open circles show hypocenter locations shallower than $20 \mathrm{~km}$ and open triangles show hypocenters with depths of $20 \mathrm{~km}$ and deeper. Hypocenter symbols are scaled with magnitude. Seismograph stations are shown by open squares and labeled by station code. Solid triangles are used to show volcanic centers and solid squares are used to show other points of interest. See Appendix B for station information. 
Mount Spurr Seismicity
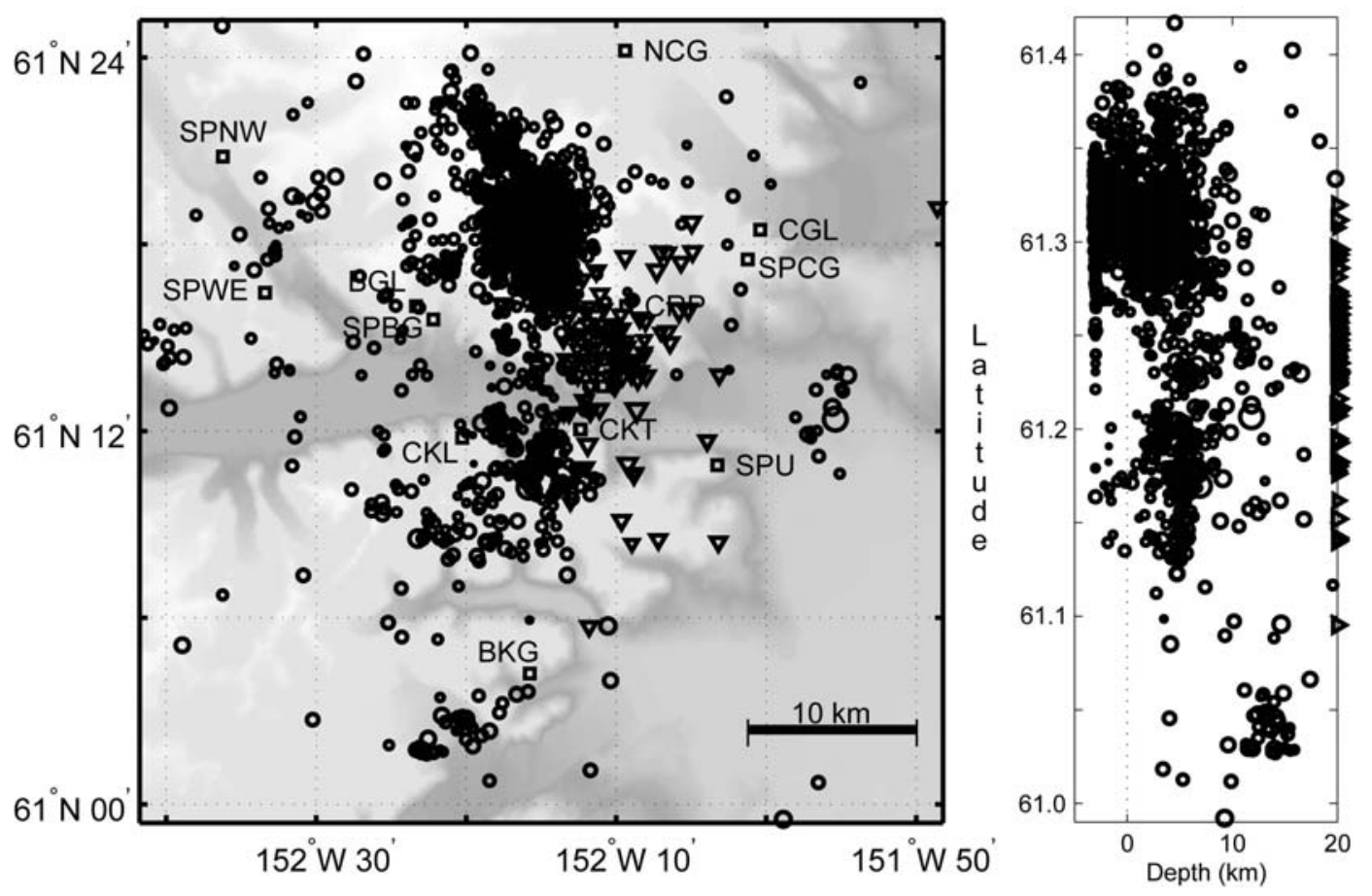

Mag. Symb. Size
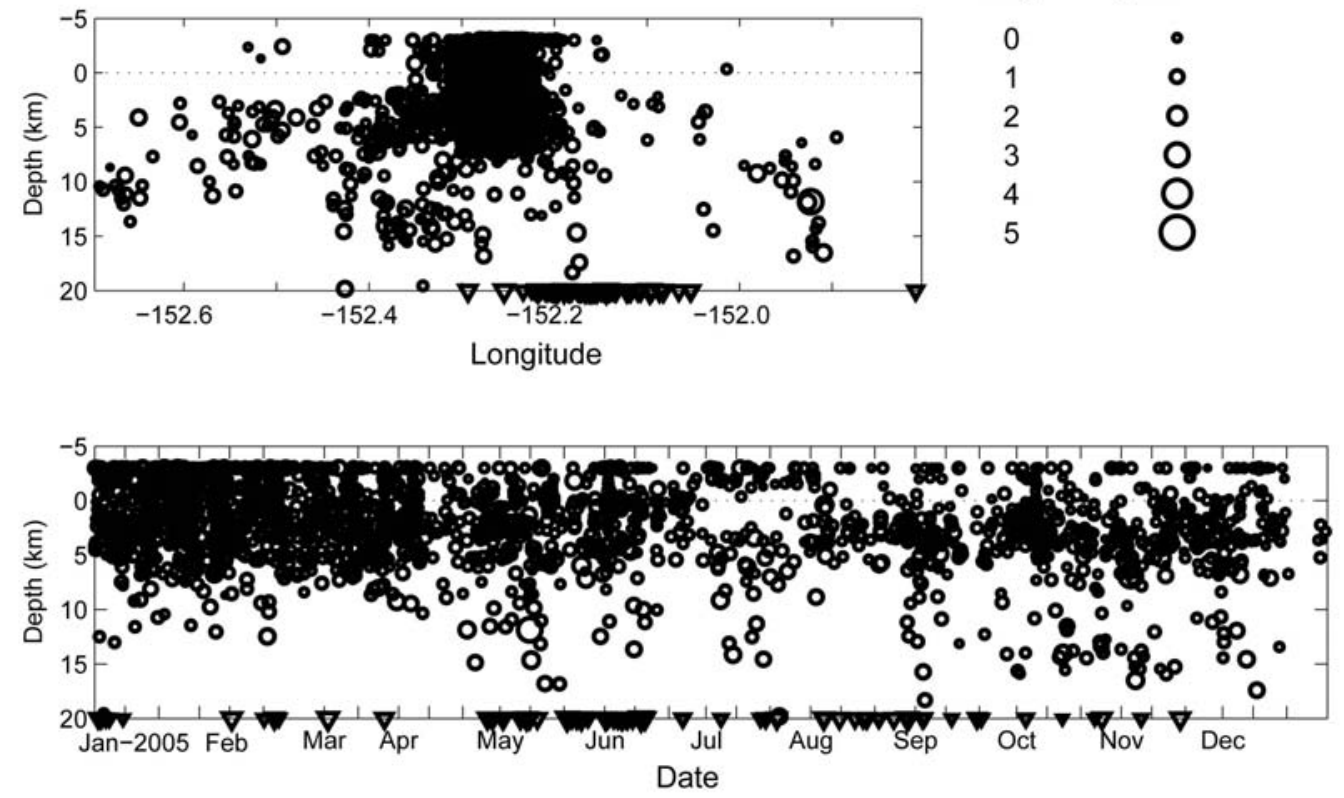

Figure A2. Summary plots of 2,386 earthquakes located near Mount Spurr in 2005. Open circles show hypocenter locations shallower than $20 \mathrm{~km}$ and open triangles show hypocenters with depths of $20 \mathrm{~km}$ and deeper. Hypocenter symbols are scaled with magnitude. Seismograph stations are shown by open squares and labeled by station code. Solid triangles are used to show volcanic centers and solid squares are used to show other points of interest. See Appendix B for station information. 
Redoubt Volcano Seismicity
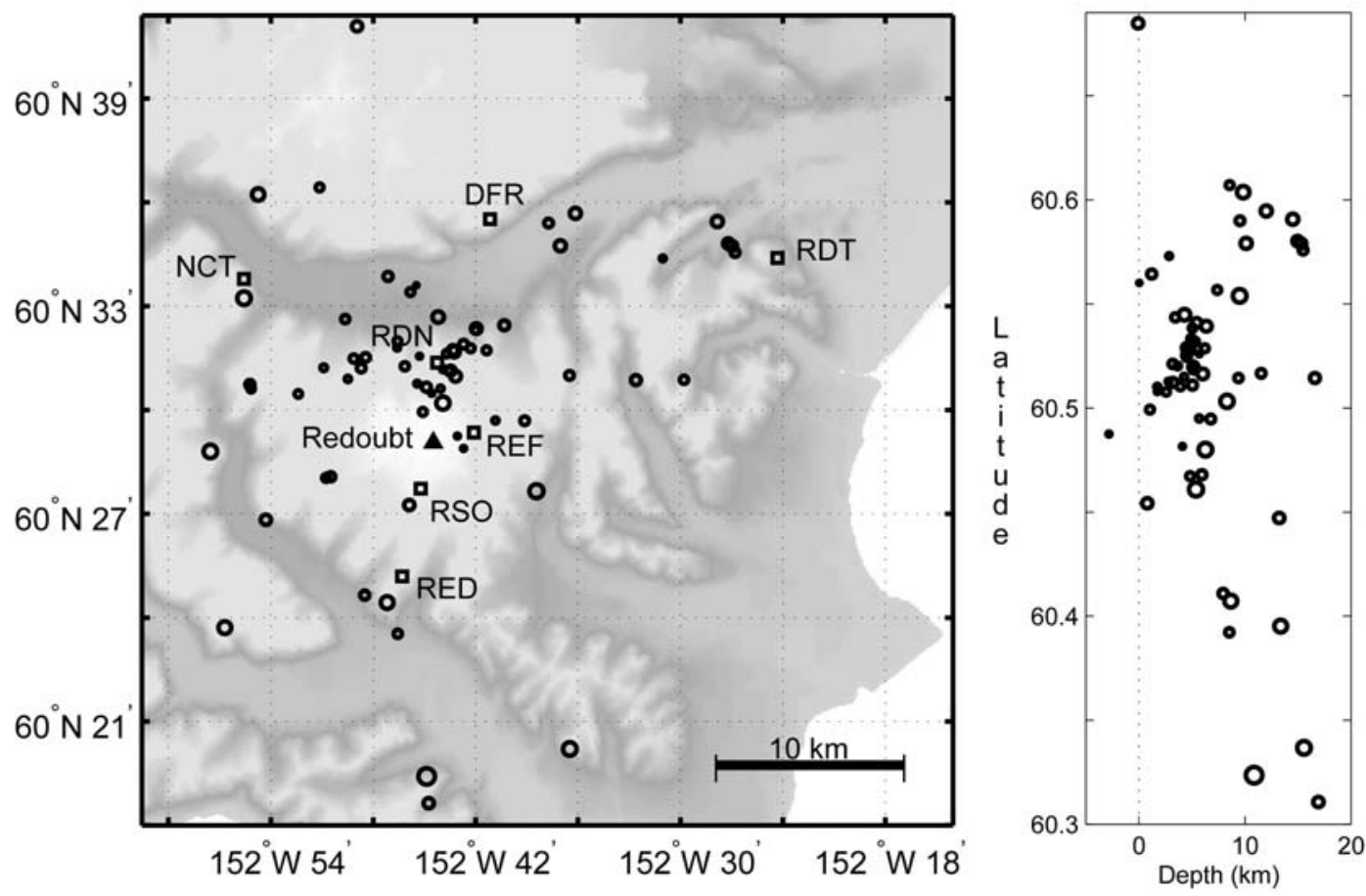

Mag. Symb. Size
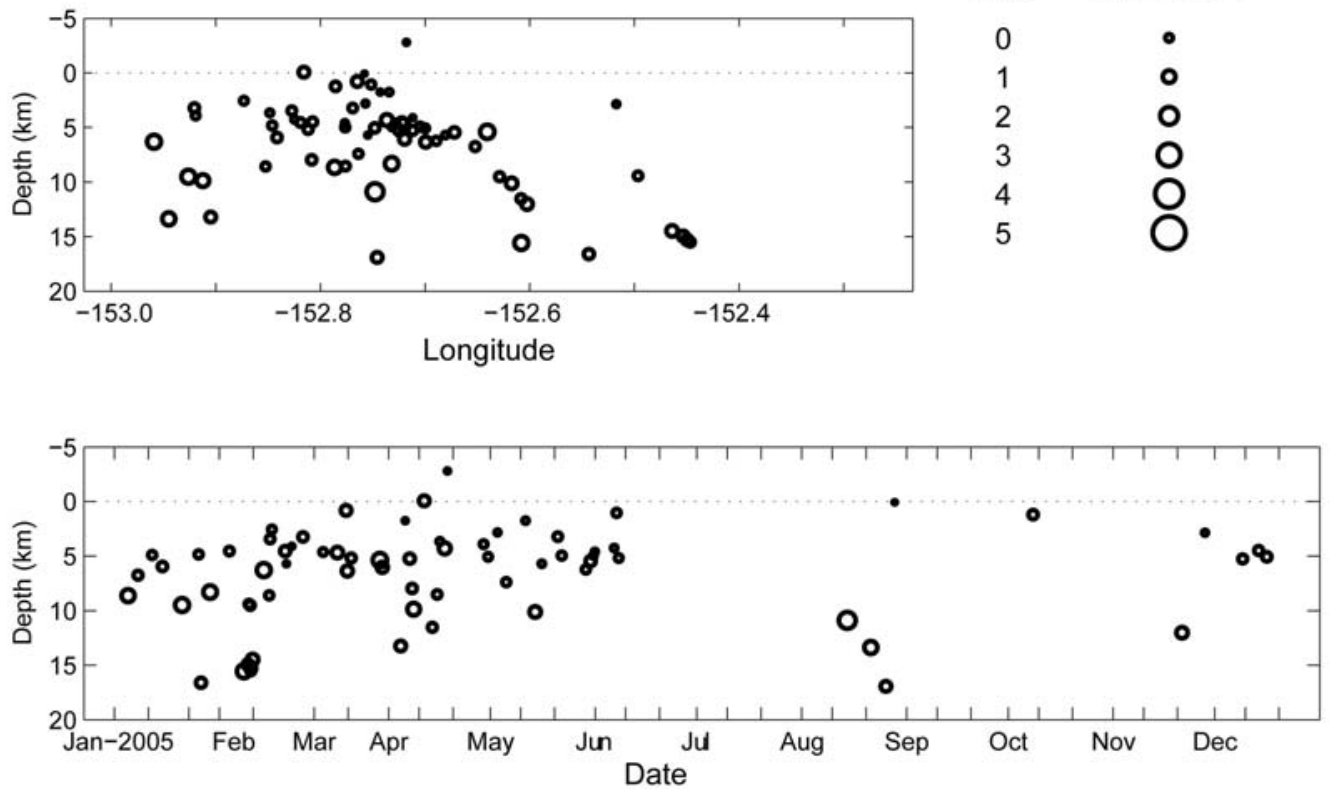

Figure A3. Summary plots of 68 earthquakes located near Redoubt Volcano in 2005. Open circles show hypocenter locations shallower than $20 \mathrm{~km}$ and open triangles show hypocenters with depths of $20 \mathrm{~km}$ and deeper. Hypocenter symbols are scaled with magnitude. Seismograph stations are shown by open squares and labeled by station code. Solid triangles are used to show volcanic centers and solid squares are used to show other points of interest. See Appendix B for station information. 
Iliamna Volcano Seismicity
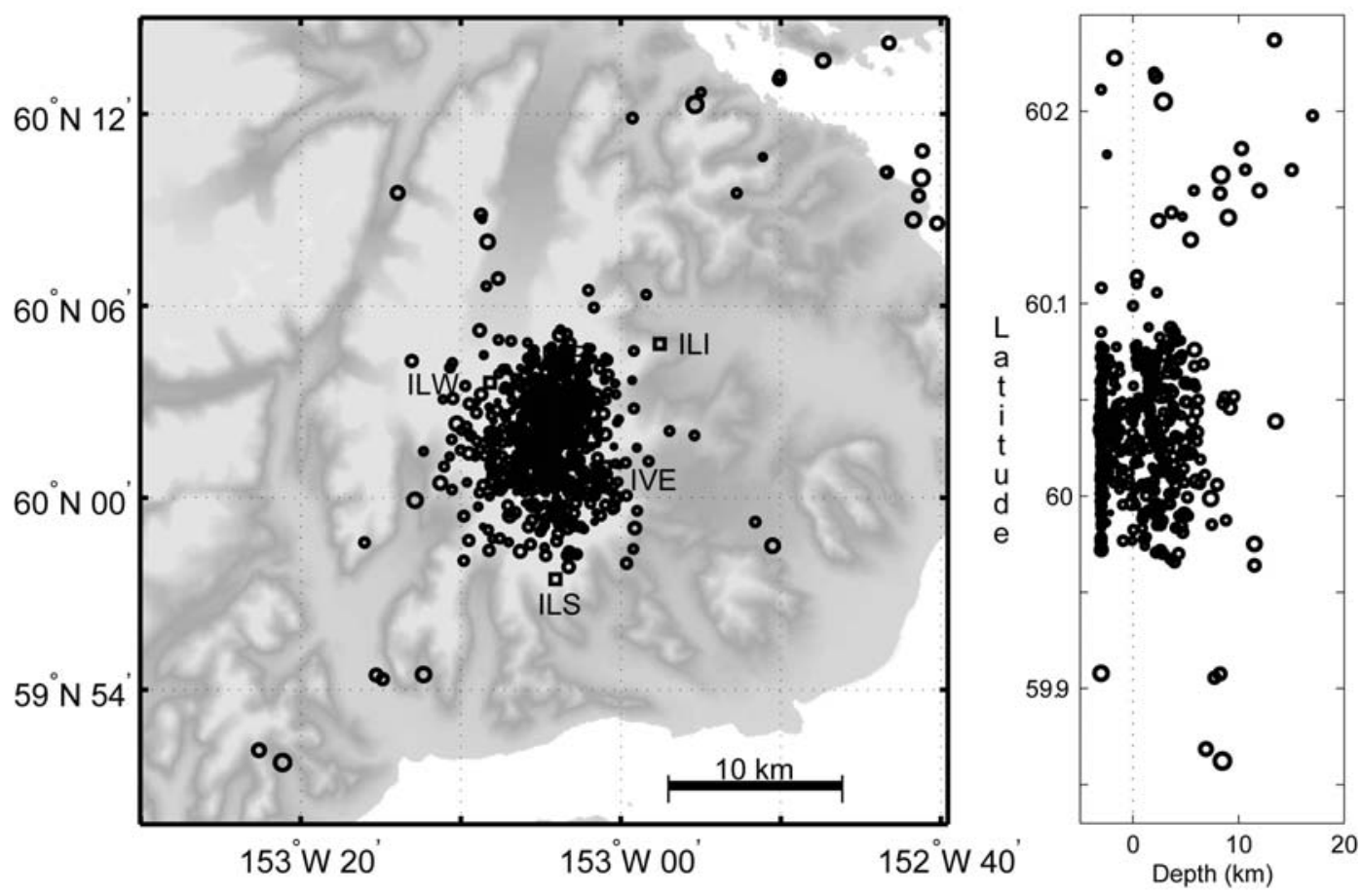

Mag. Symb. Size
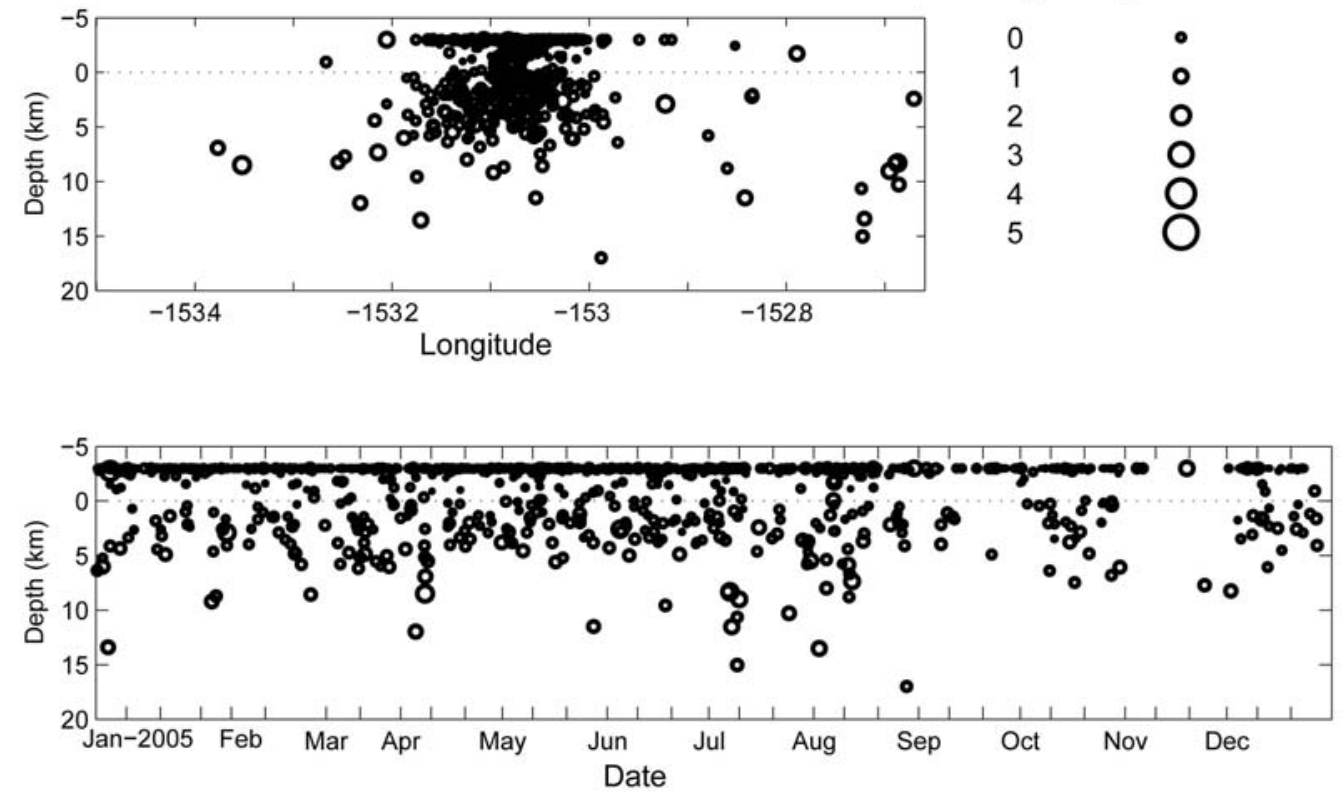

Figure A4. Summary plots of 995 earthquakes located near Iliamna Volcano in 2005. Open circles show hypocenter locations shallower than $20 \mathrm{~km}$ and open triangles show hypocenters with depths of $20 \mathrm{~km}$ and deeper. Hypocenter symbols are scaled with magnitude. Seismograph stations are shown by open squares and labeled by station code. Solid triangles are used to show volcanic centers and solid squares are used to show other points of interest. See Appendix B for station information. 

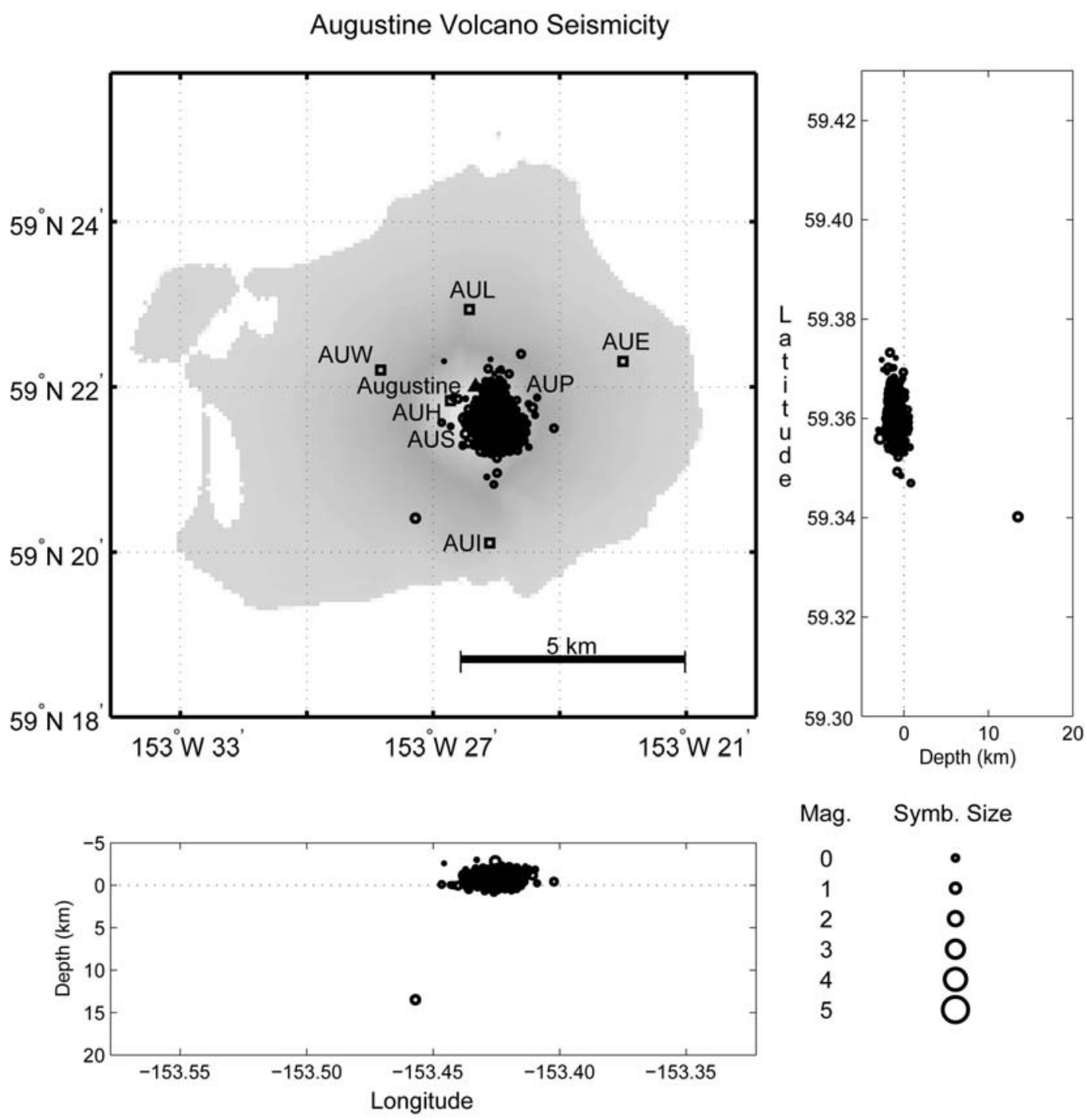

Mag. Symb. Size
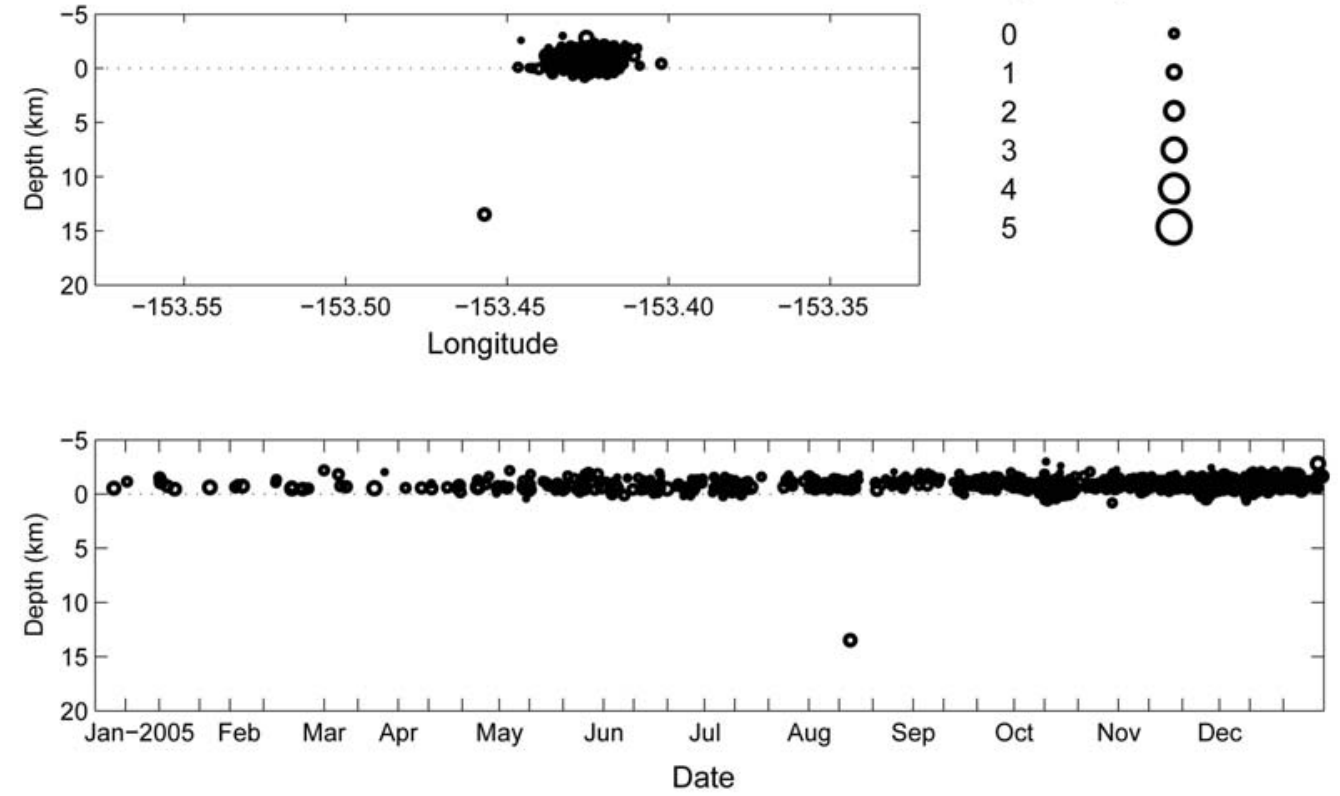

Figure A5. Summary plots of 1,189 earthquakes located near Augustine Volcano in 2005. Open circles show hypocenter locations shallower than $20 \mathrm{~km}$ and open triangles show hypocenters with depths of $20 \mathrm{~km}$ and deeper. Hypocenter symbols are scaled with magnitude. Seismograph stations are shown by open squares and labeled by station code. Solid triangles are used to show volcanic centers and solid squares are used to show other points of interest. See Appendix B for station information. 
Katmai Volcanic Cluster Seismicity
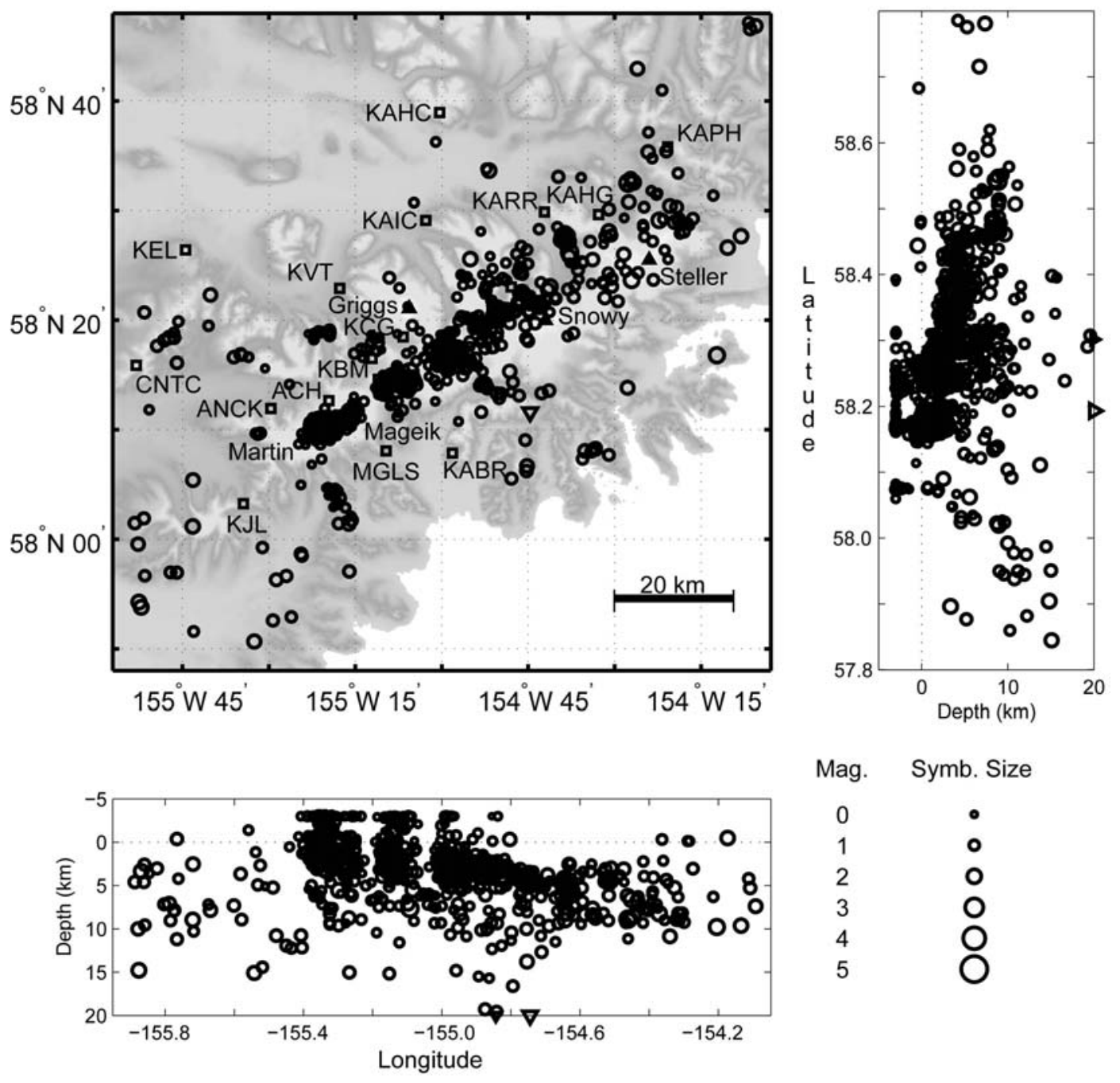

Mag. Symb. Size

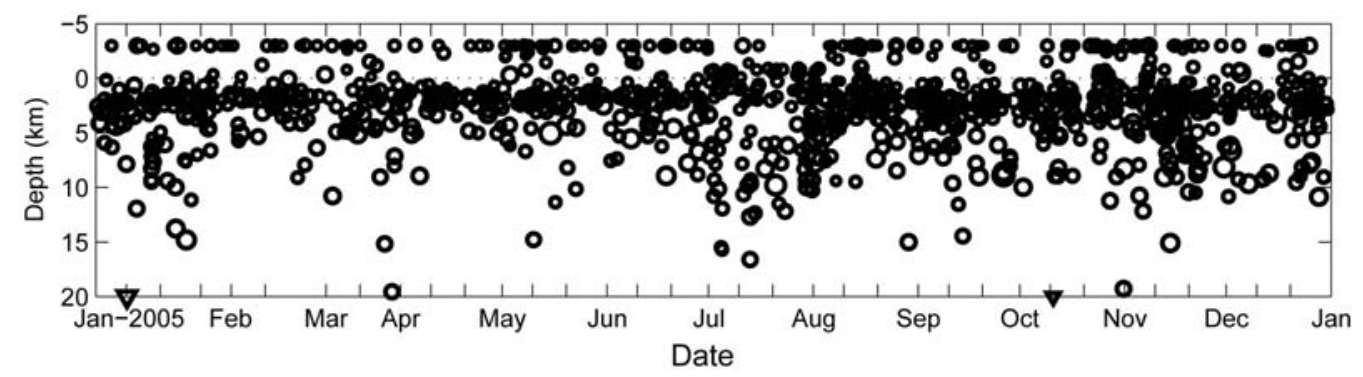

Figure A6. Summary plots of 1,138 earthquakes located near the Katmai volcanic cluster in 2005. Open circles show hypocenter locations shallower than $20 \mathrm{~km}$ and open triangles show hypocenters with depths of $20 \mathrm{~km}$ and deeper. Hypocenter symbols are scaled with magnitude. Seismograph stations are shown by open squares and labeled by station code. Solid triangles are used to show volcanic centers and solid squares are used to show other points of interest. See Appendix B for station information... 
Snowy Mountain Seismicity
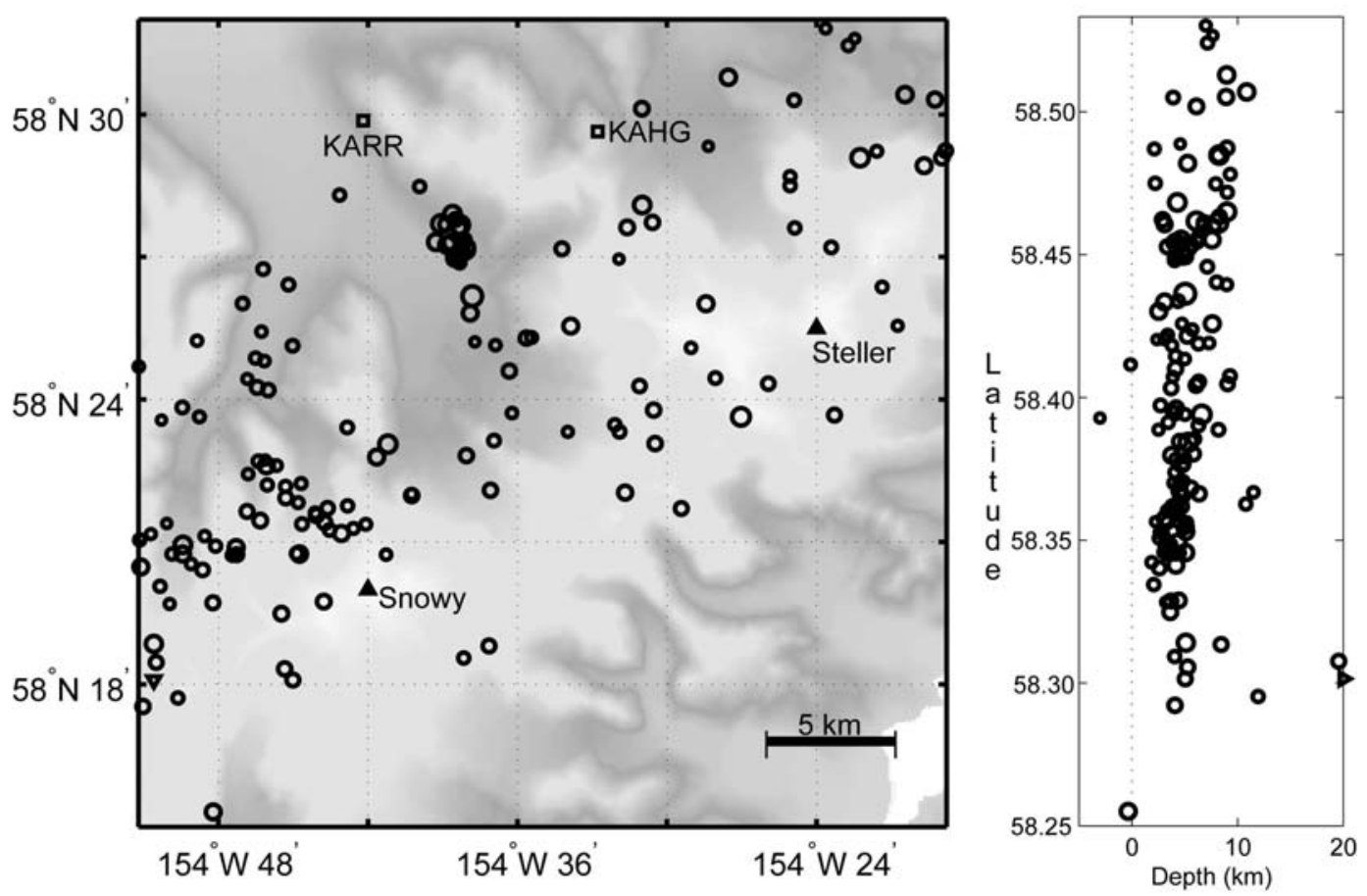

Mag. Symb. Size
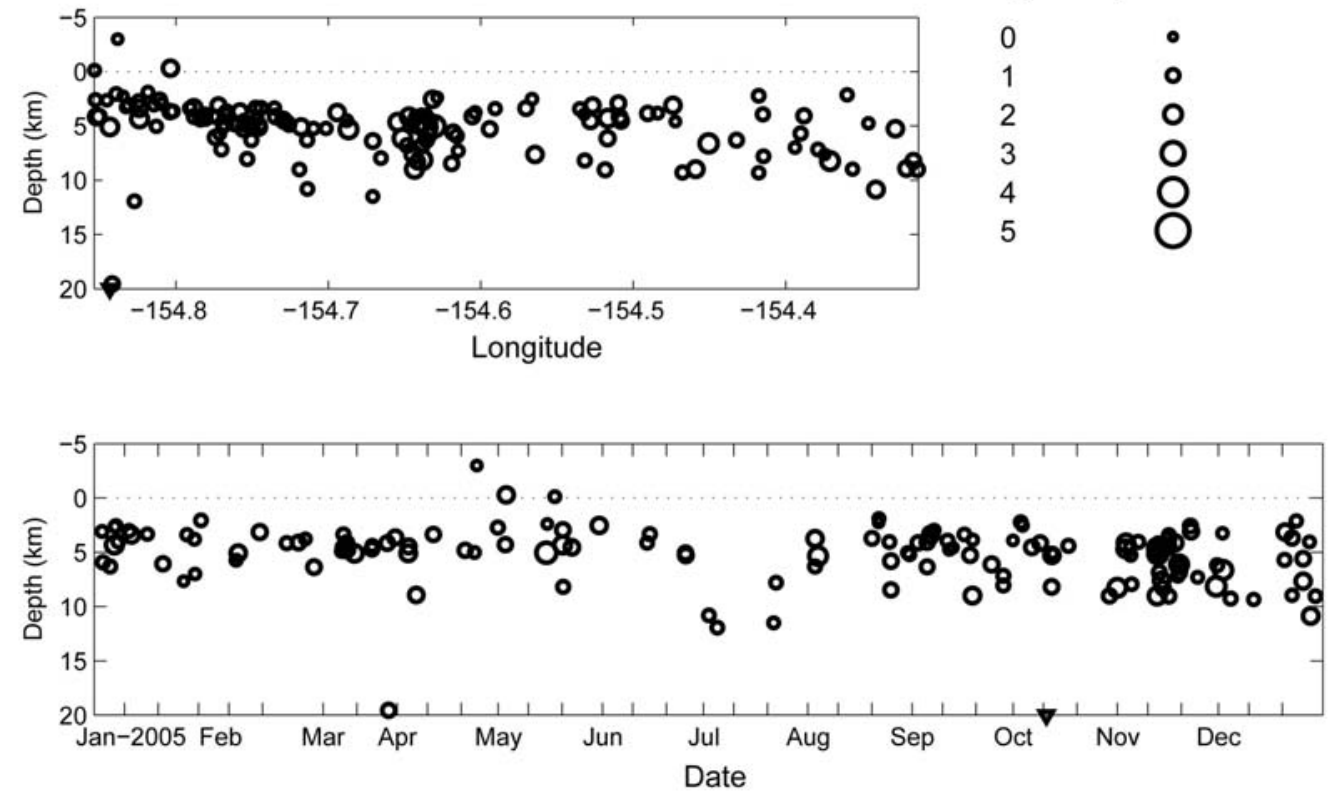

Figure A7. Summary plots of 145 earthquakes located near Snowy Mountain in the Katmai volcanic cluster in 2005. Open circles show hypocenter locations shallower than $20 \mathrm{~km}$ and open triangles show hypocenters with depths of $20 \mathrm{~km}$ and deeper. Hypocenter symbols are scaled with magnitude. Seismograph stations are shown by open squares and labeled by station code. (See Appendix B for station information). Solid triangles are used to show volcanic centers and solid squares are used to show other points of interest. 
Mount Griggs Seismicity
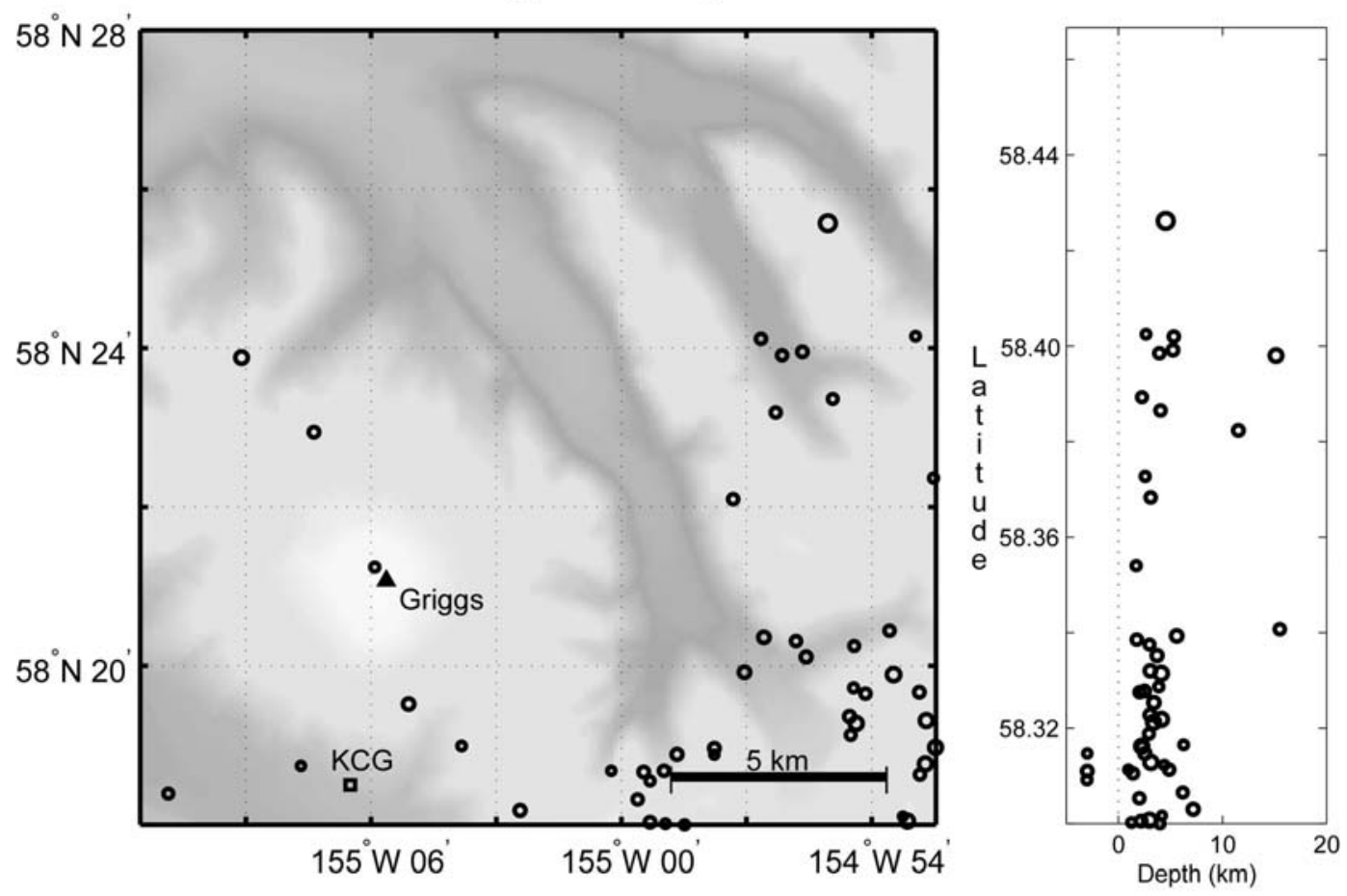

Mag. Symb. Size
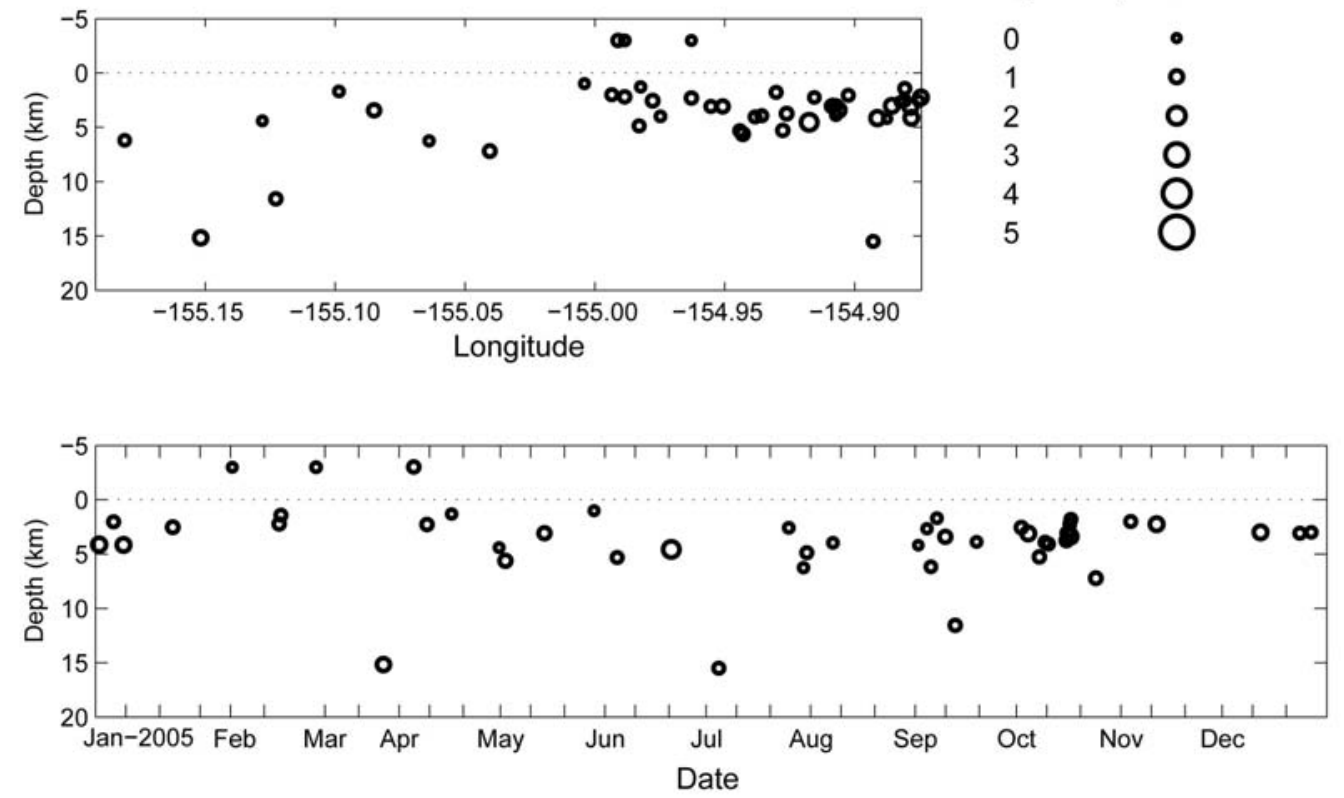

Figure A8. Summary plots of 47 earthquakes located near Mount Griggs in the Katmai volcanic cluster in 2005. Open circles show hypocenter locations shallower than $20 \mathrm{~km}$ and open triangles show hypocenters with depths of $20 \mathrm{~km}$ and deeper. Hypocenter symbols are scaled with magnitude. Seismograph stations are shown by open squares and labeled by station code. Solid triangles are used to show volcanic centers and solid squares are used to show other points of interest. See Appendix B for station information. Several earthquakes that appear on this figure appear on other figures. 
Mount Katmai Seismicity
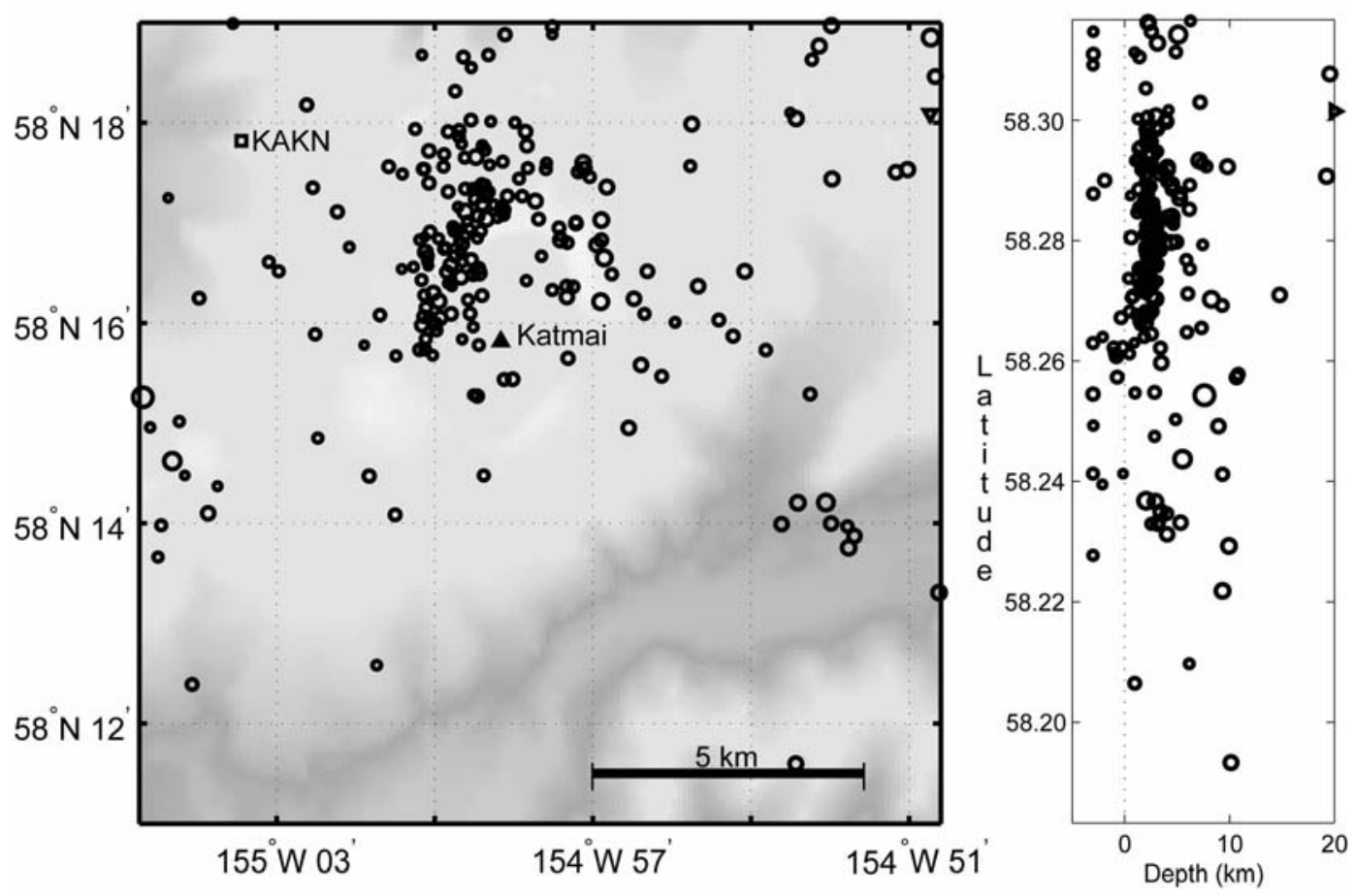

Mag. Symb. Size

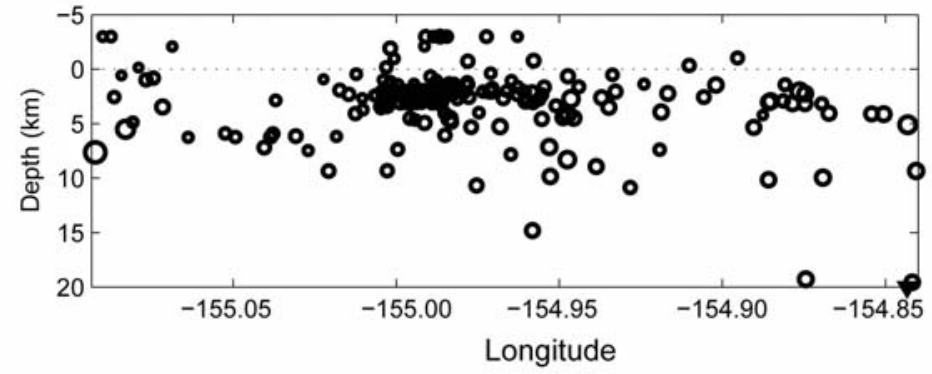

$\begin{array}{ll}0 & 0 \\ 1 & \circ \\ 2 & \circ \\ 3 & 0 \\ 4 & \bigcirc \\ 5 & \bigcirc\end{array}$

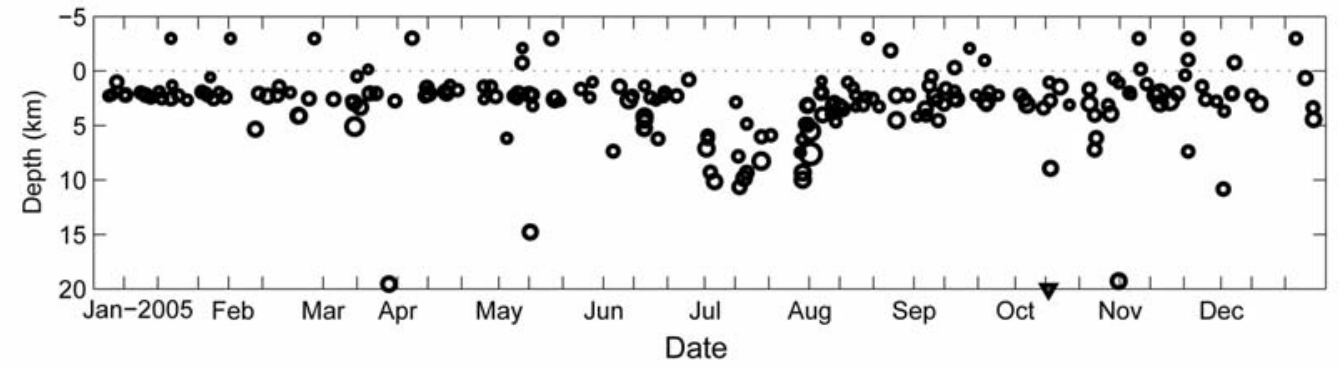

Figure A9. Summary plots of 209 earthquakes located near Mount Katmai in the Katmai volcanic cluster in 2005. Open circles show hypocenter locations shallower than $20 \mathrm{~km}$ and open triangles show hypocenters with depths of $20 \mathrm{~km}$ and deeper. Hypocenter symbols are scaled with magnitude. Seismograph stations are shown by open squares and labeled by station code. Solid triangles are used to show volcanic centers and solid squares are used to show other points of interest. See Appendix B for station information. Several earthquakes that appear on this figure appear on other figures. 
Novarupta/Trident Volcano Seismicity
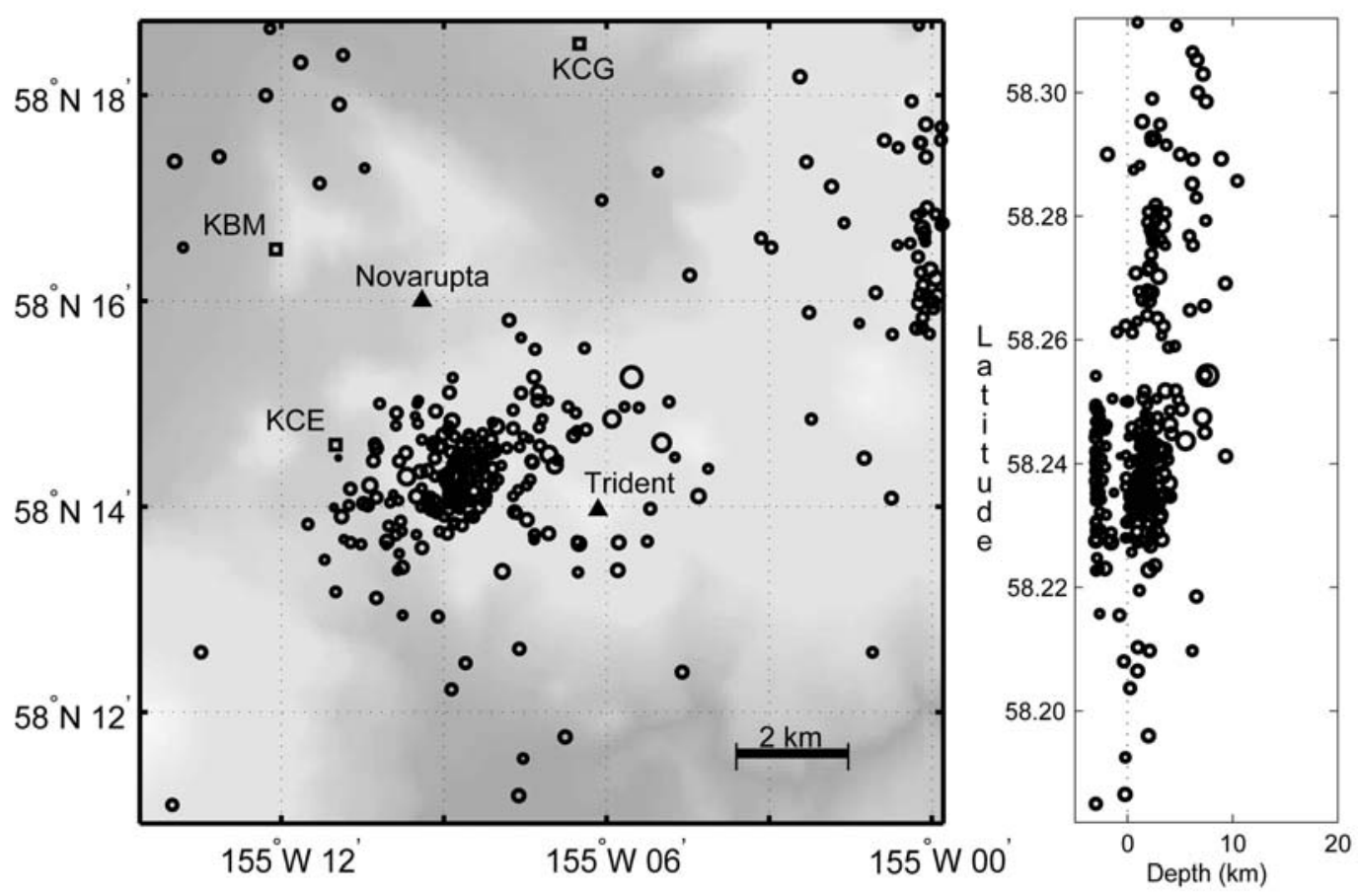

Mag. Symb. Size
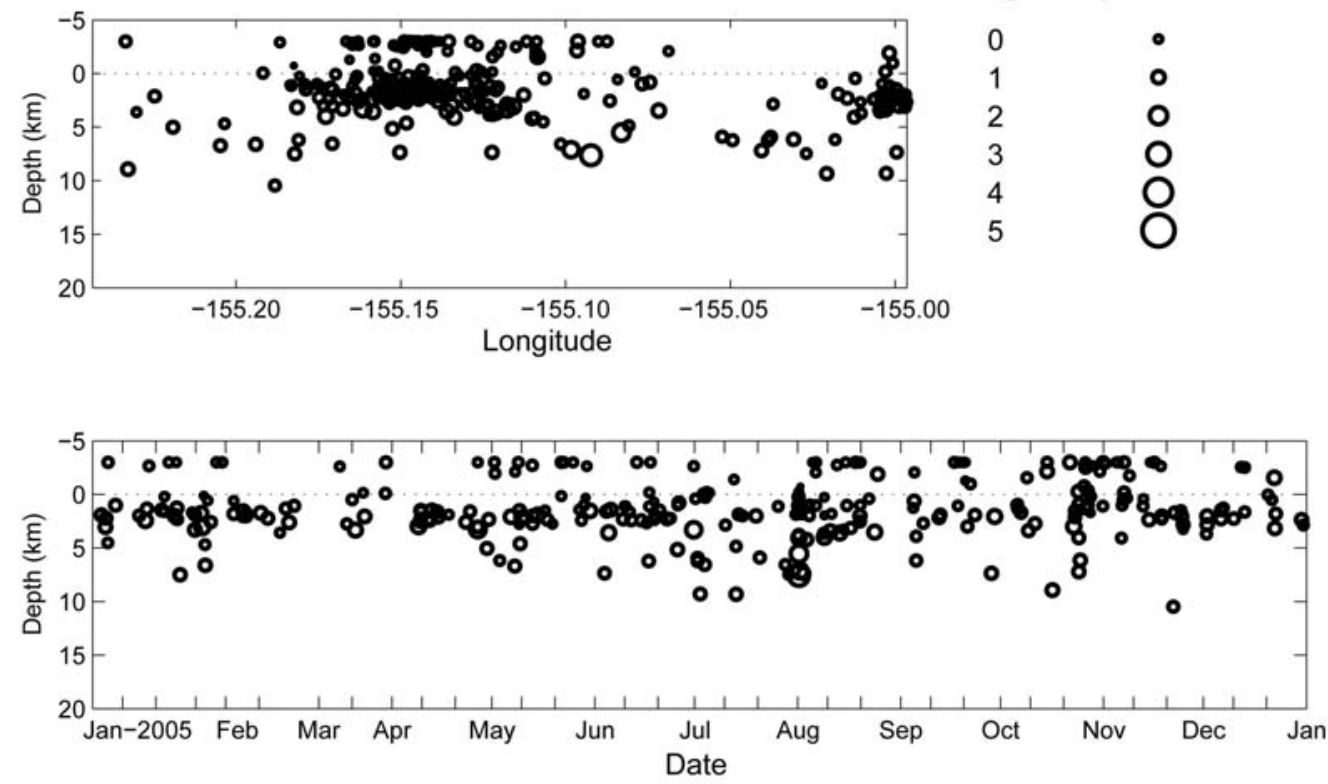

Figure A10. Summary plots of 287 earthquakes located near Novarupta and Trident Volcano in the Katmai volcanic cluster in 2005. Open circles show hypocenter locations shallower than $20 \mathrm{~km}$ and open triangles show hypocenters with depths of $20 \mathrm{~km}$ and deeper. Hypocenter symbols are scaled with magnitude. Seismograph stations are shown by open squares and labeled by station code. Solid triangles are used to show volcanic centers and solid squares are used to show other points of interest. See Appendix B for station information. Several earthquakes that appear on this figure appear on other figures. 
Mount Martin/Mount Mageik Seismicity
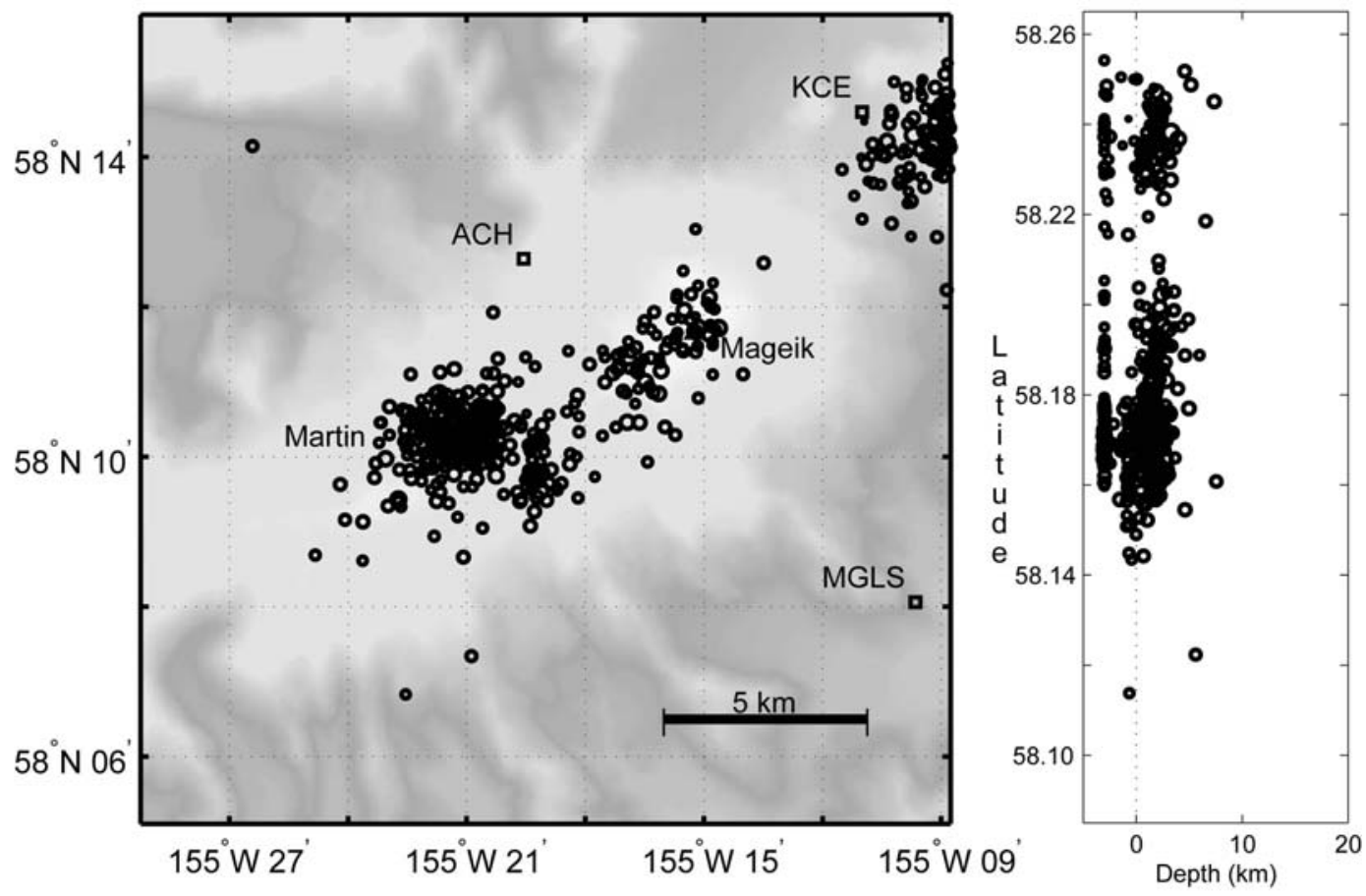

Mag. Symb. Size
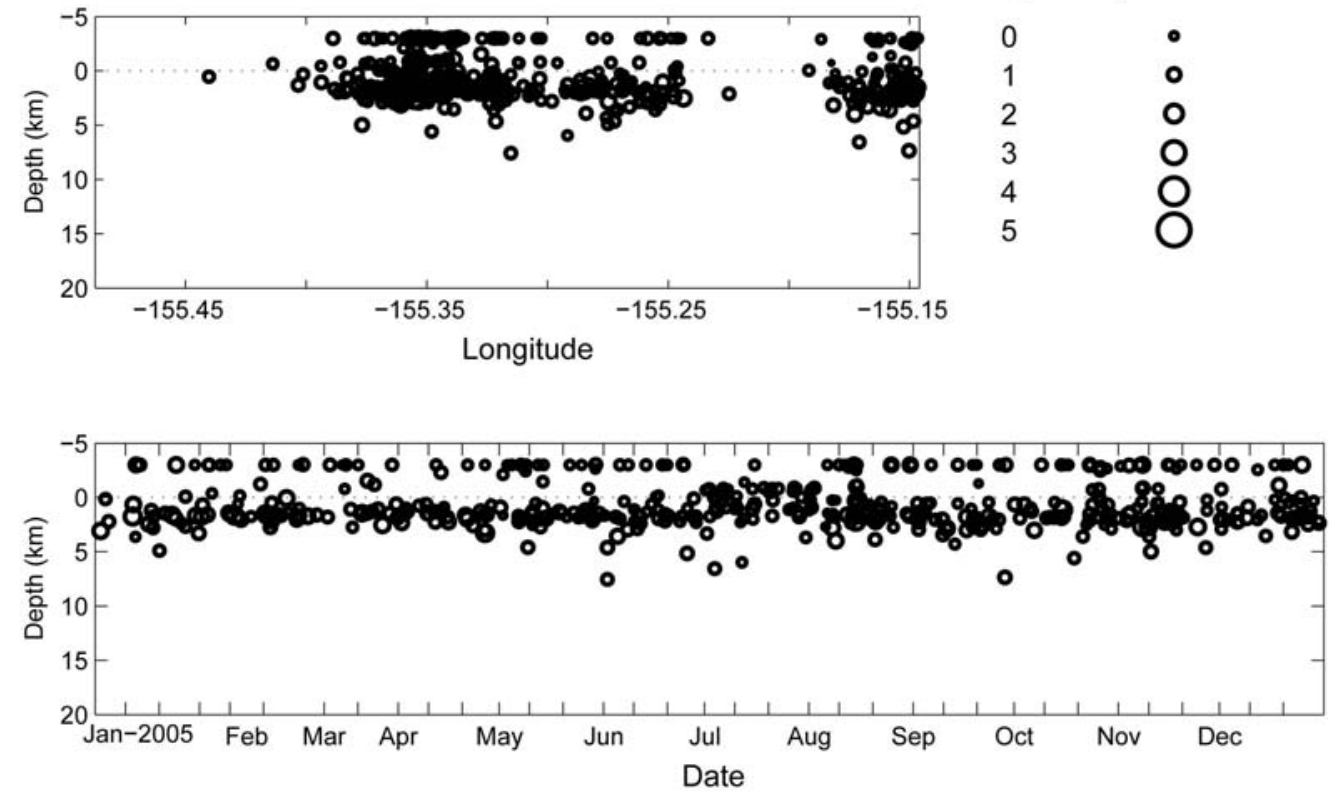

Figure A11. Summary plots of 495 earthquakes located near Mount Mageik and Mount Martin in the Katmai volcanic cluster in 2005. Open circles scaled with magnitude show hypocenter locations. Seismograph stations are shown by open squares and labeled by station code. Solid triangles are used to show volcanic centers and solid squares are used to show other points of interest. See Appendix B for station information. Several earthquakes that appear on this figure appear on other figures. 
Mount Peulik Seismicity
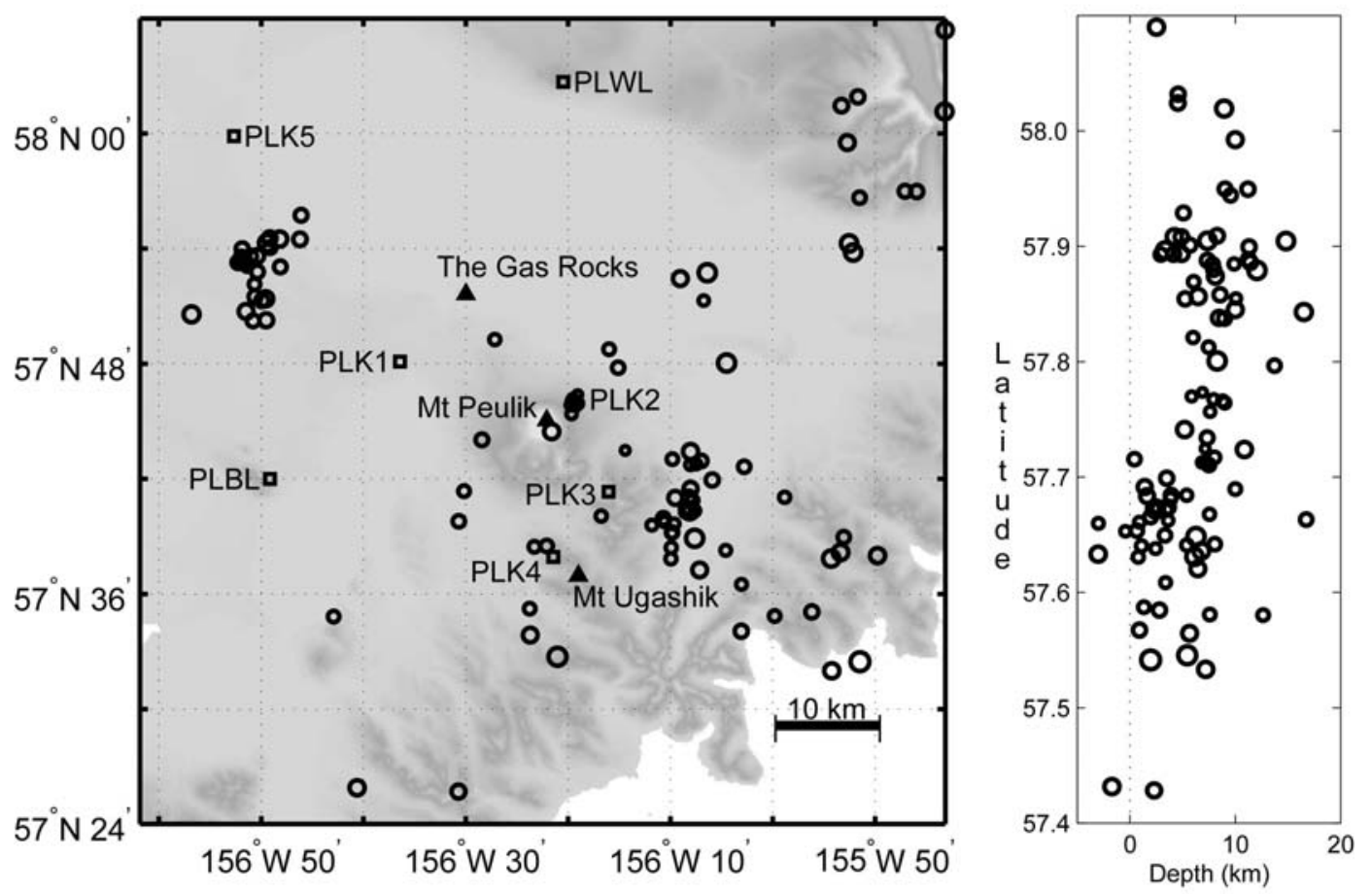

Mag. Symb. Size
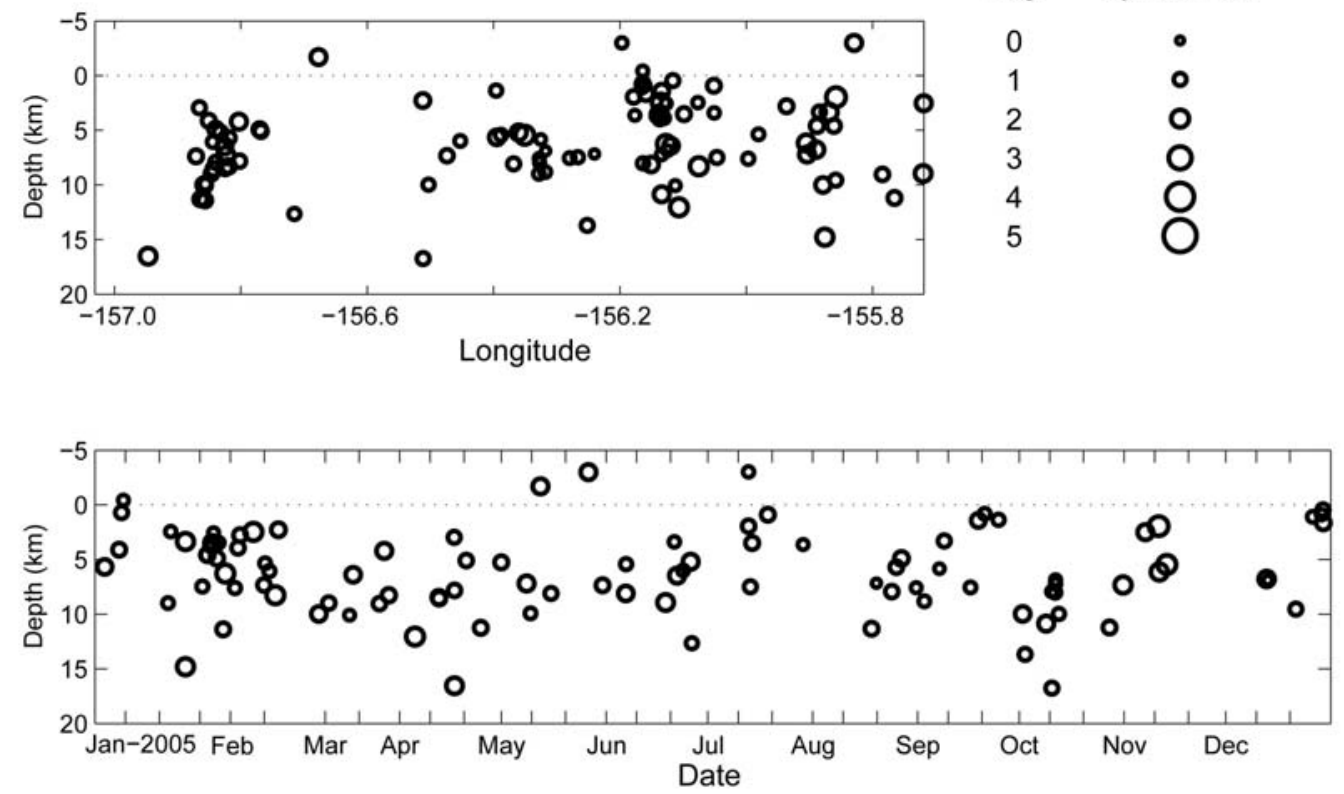

Figure A12. Summary plots of 101 earthquakes located near Mount Peulik in 2005. Open circles show hypocenter locations shallower than $20 \mathrm{~km}$ and open triangles show hypocenters with depths of $20 \mathrm{~km}$ and deeper. Hypocenter symbols are scaled with magnitude. Seismograph stations are shown by open squares and labeled by station code. Solid triangles are used to show volcanic centers and solid squares are used to show other points of interest. See Appendix B for station information. 
Aniakchak Crater Seismicity
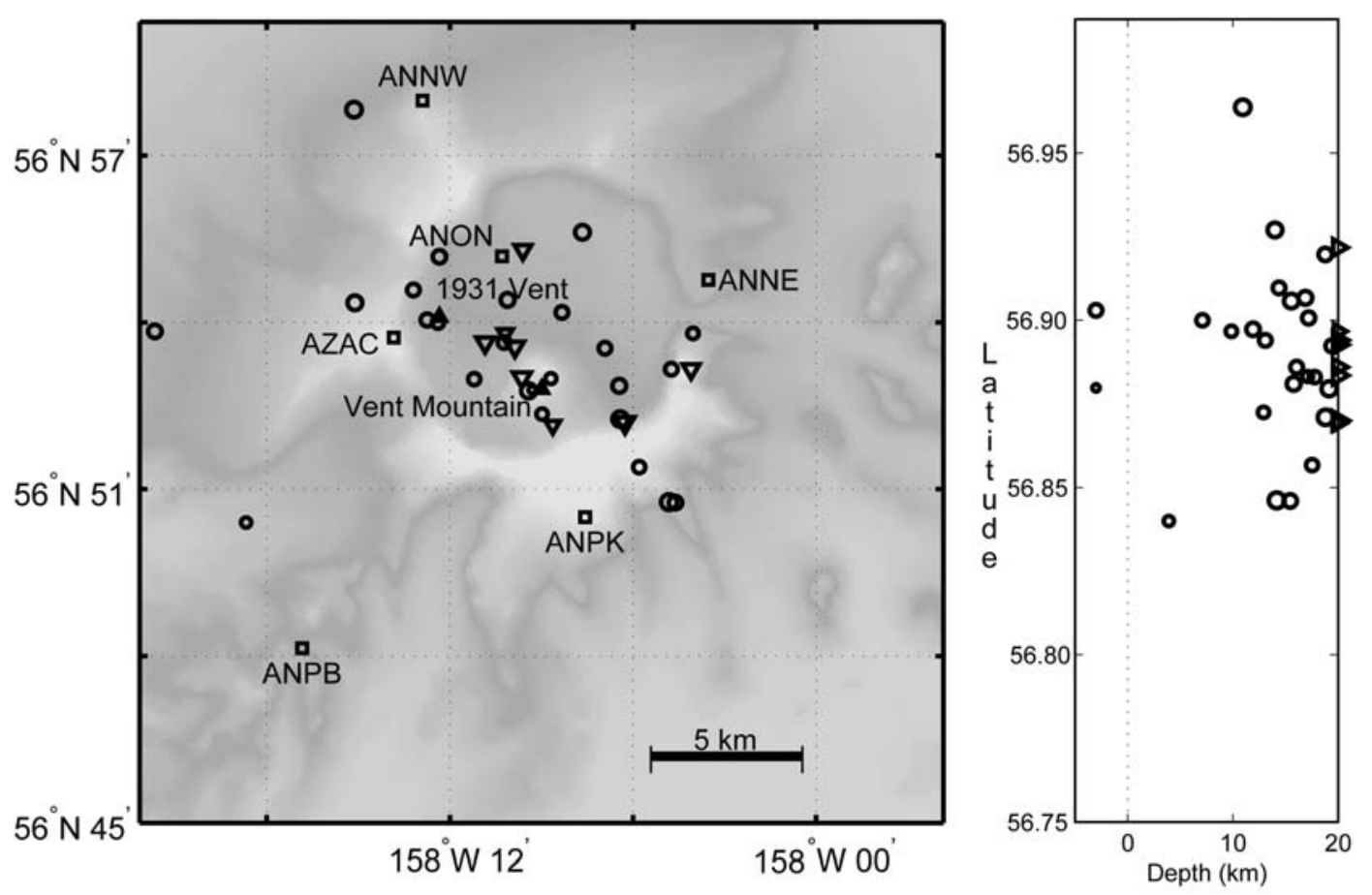

Mag. Symb. Size
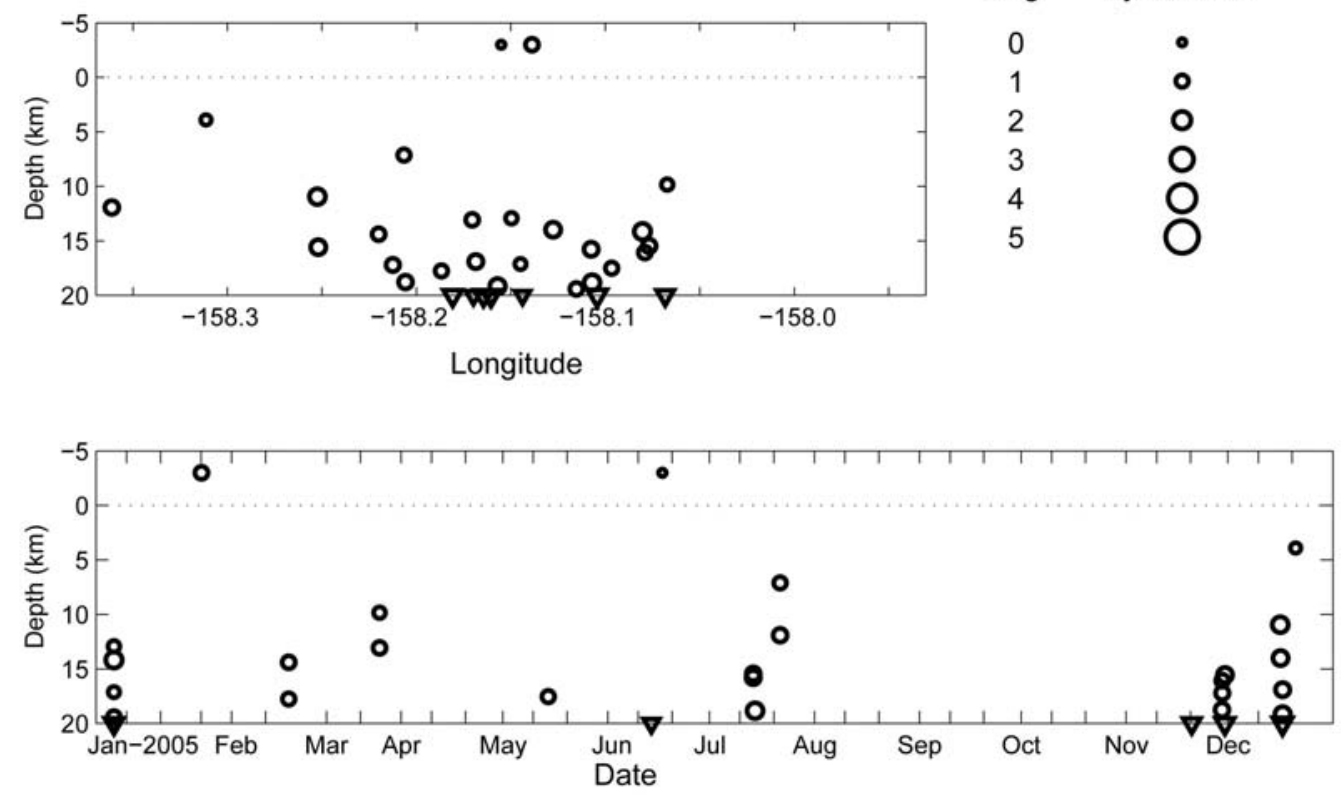

Figure A13. Summary plots of 33 earthquakes located near Aniakchak Crater in 2005. Open circles show hypocenter locations shallower than $20 \mathrm{~km}$ and open triangles show hypocenters with depths of $20 \mathrm{~km}$ and deeper. Hypocenter symbols are scaled with magnitude. Seismograph stations are shown by open squares and labeled by station code. Solid triangles are used to show volcanic centers and solid squares are used to show other points of interest. See Appendix B for station information. 
Mount Veniaminof Seismicity
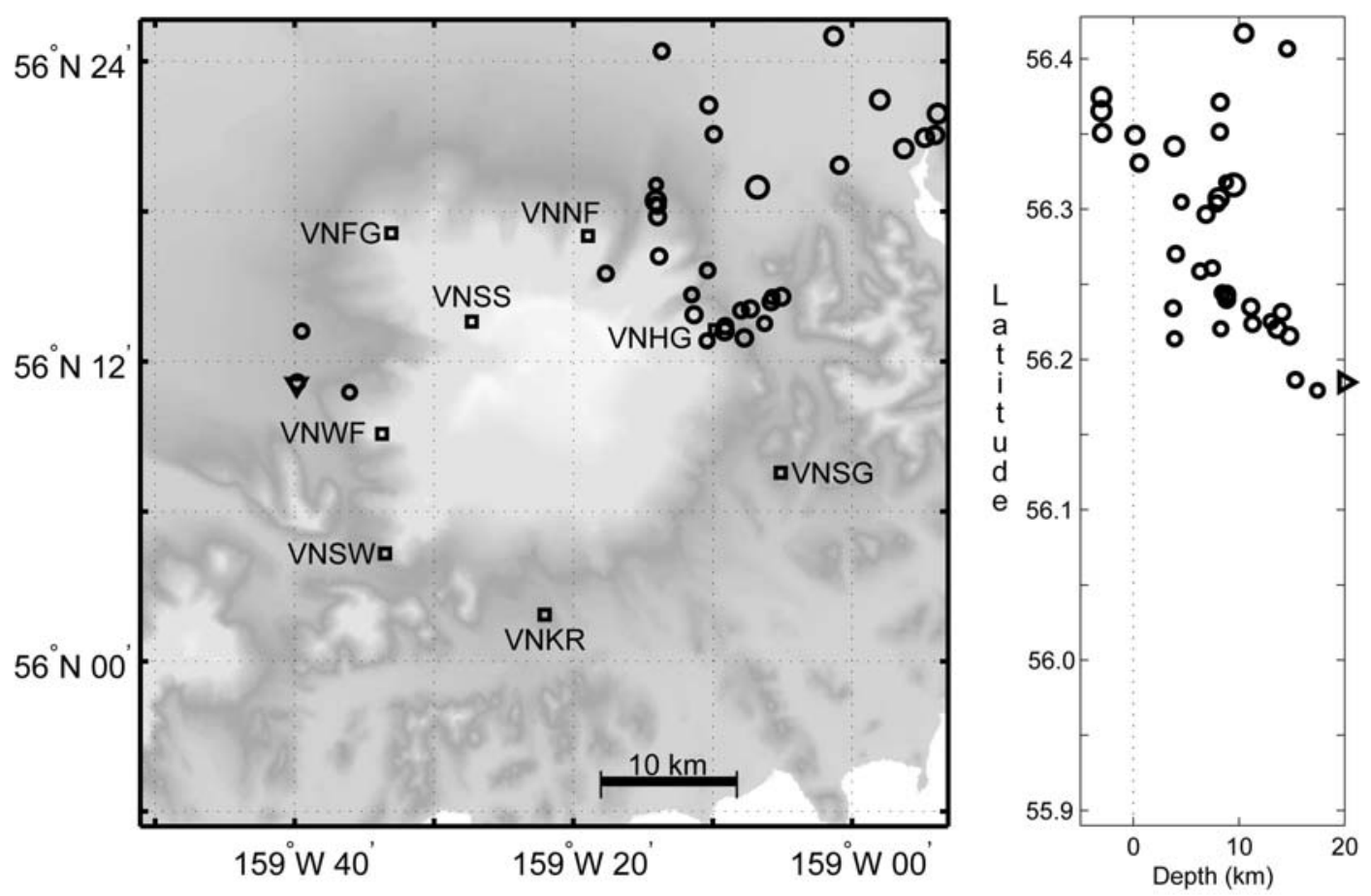

Mag. Symb. Size
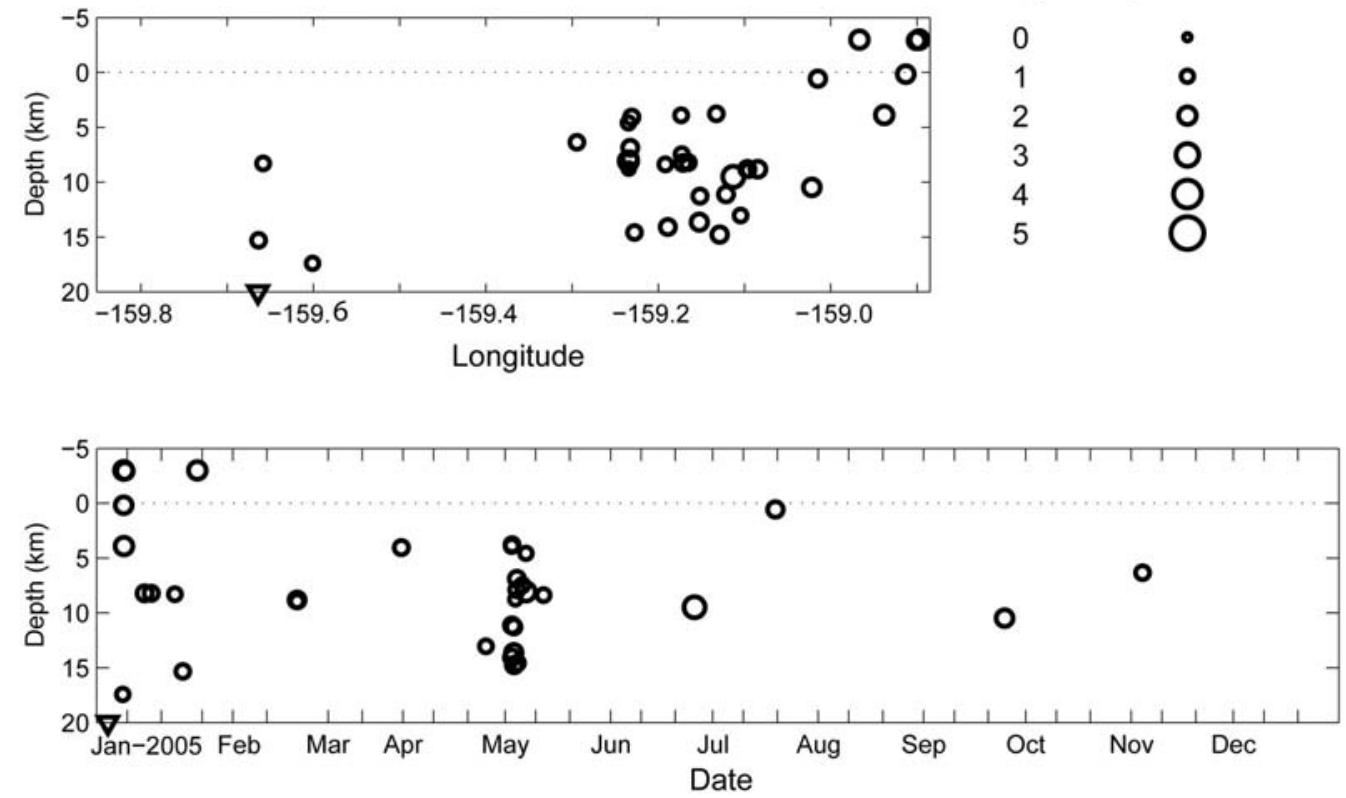

Figure A14. Summary plots of 35 earthquakes located near Mount Veniaminof in 2005. Open circles show hypocenter locations shallower than $20 \mathrm{~km}$ and open triangles show hypocenters with depths of $20 \mathrm{~km}$ and deeper. Hypocenter symbols are scaled with magnitude. Seismograph stations are shown by open squares and labeled by station code. Solid triangles are used to show volcanic centers and solid squares are used to show other points of interest. See Appendix B for station information. 
Pavlof Volcano Seismicity
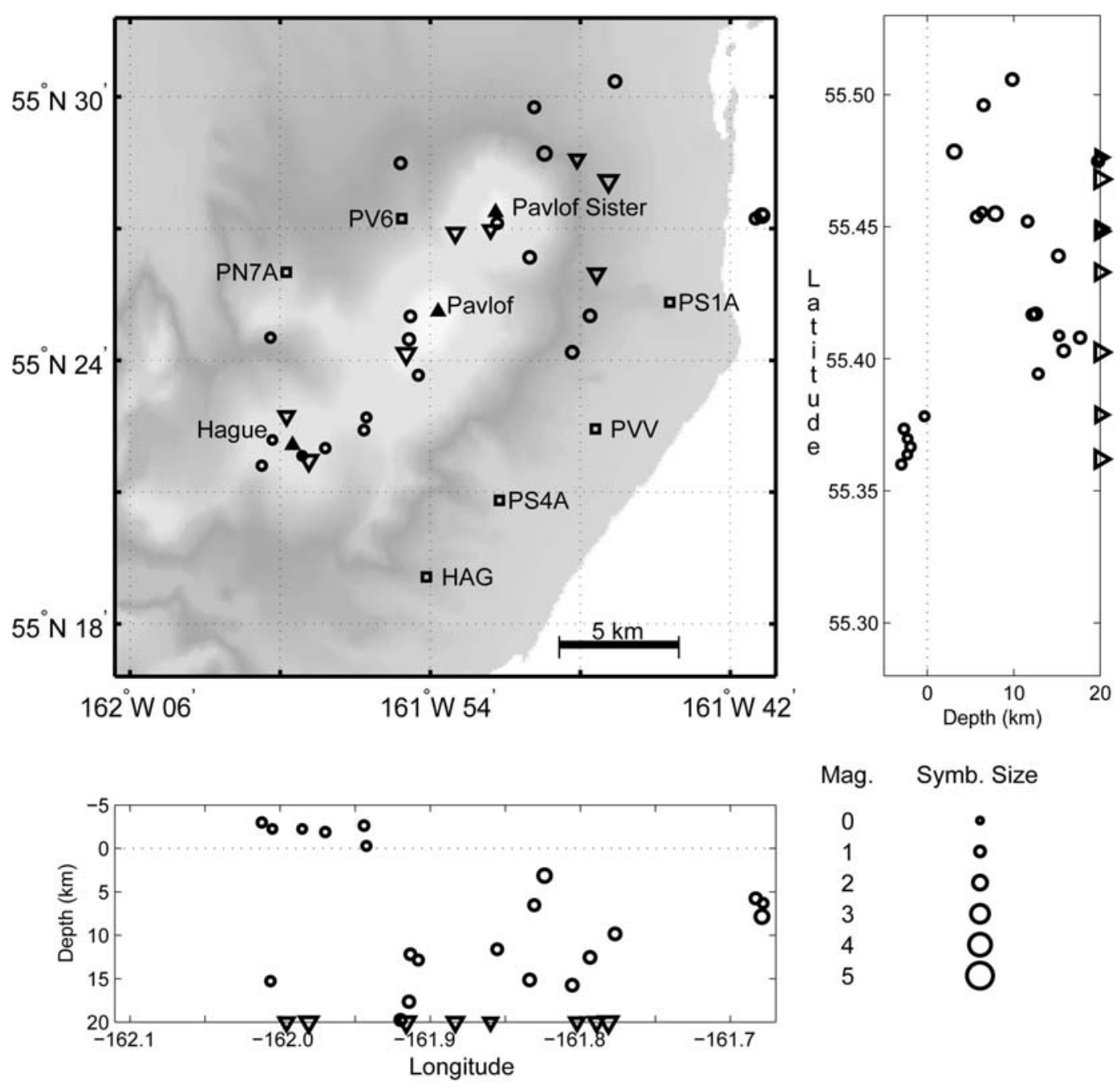

Mag. Symb. Size

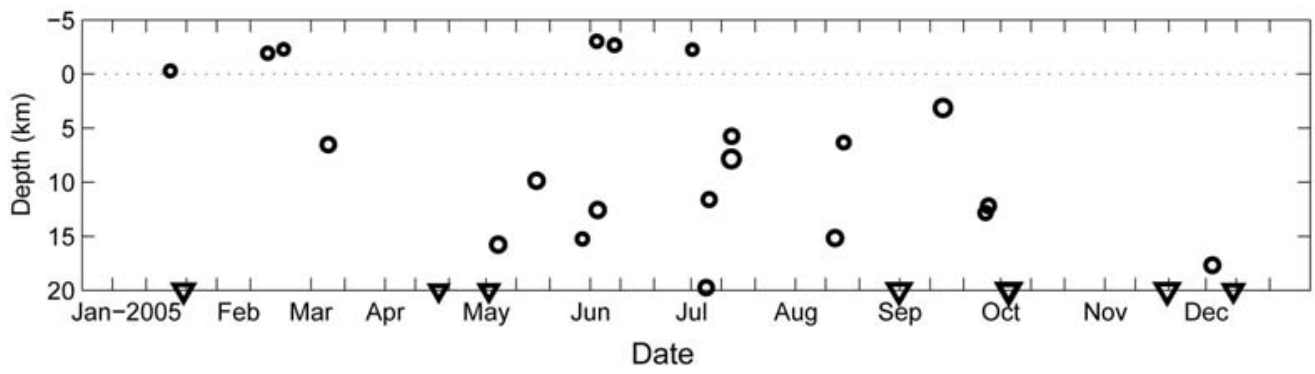

Figure A15. Summary plots of 29 earthquakes located near Pavlof Volcano in 2005. Open circles show hypocenter locations shallower than $20 \mathrm{~km}$ and open triangles show hypocenters with depths of $20 \mathrm{~km}$ and deeper. Hypocenter symbols are scaled with magnitude. Seismograph stations are shown by open squares and labeled by station code. Solid triangles are used to show volcanic centers and solid squares are used to show other points of interest. See Appendix B for station information. 
Mount Dutton Seismicity
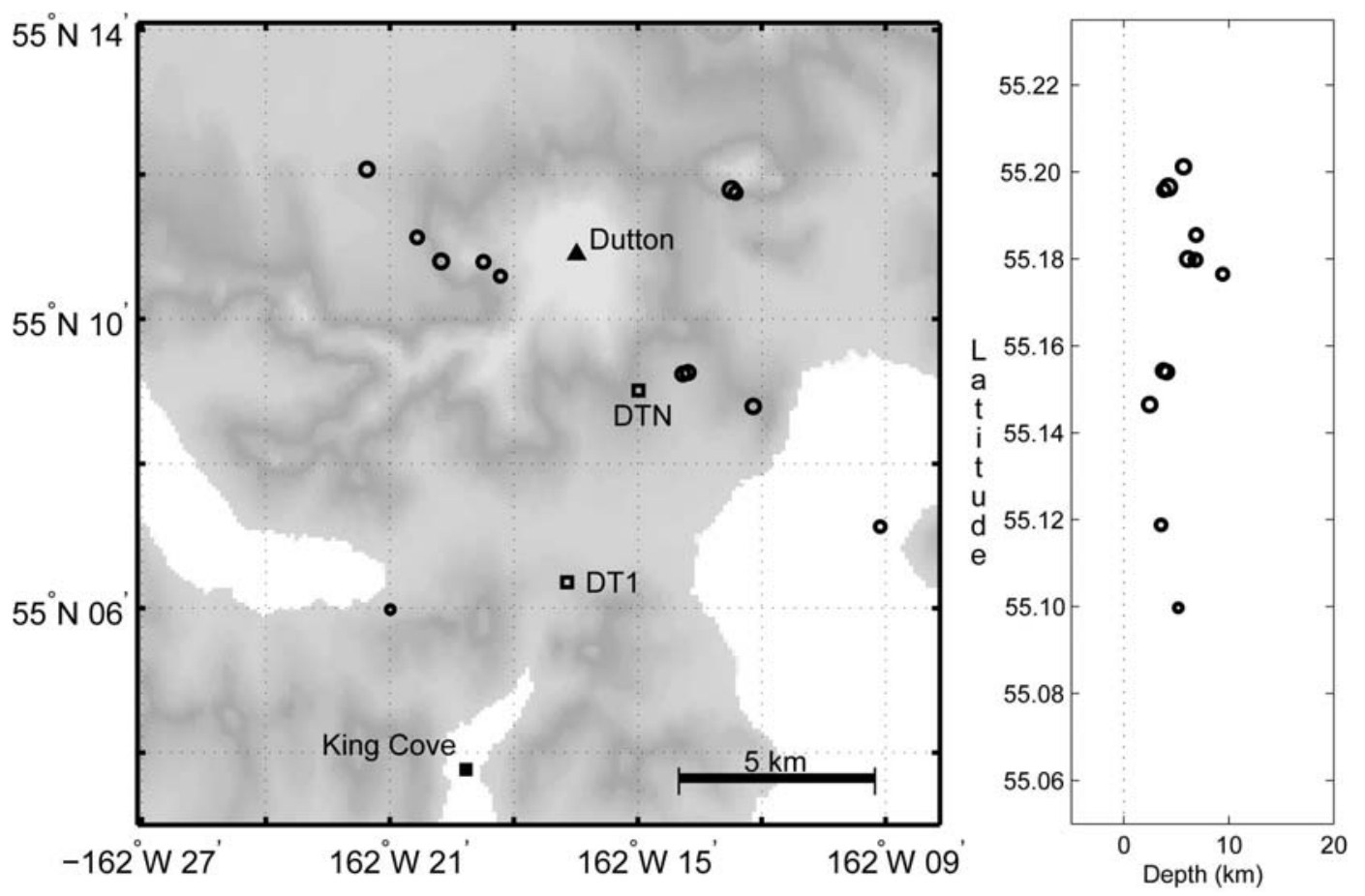

Mag. Symb. Size
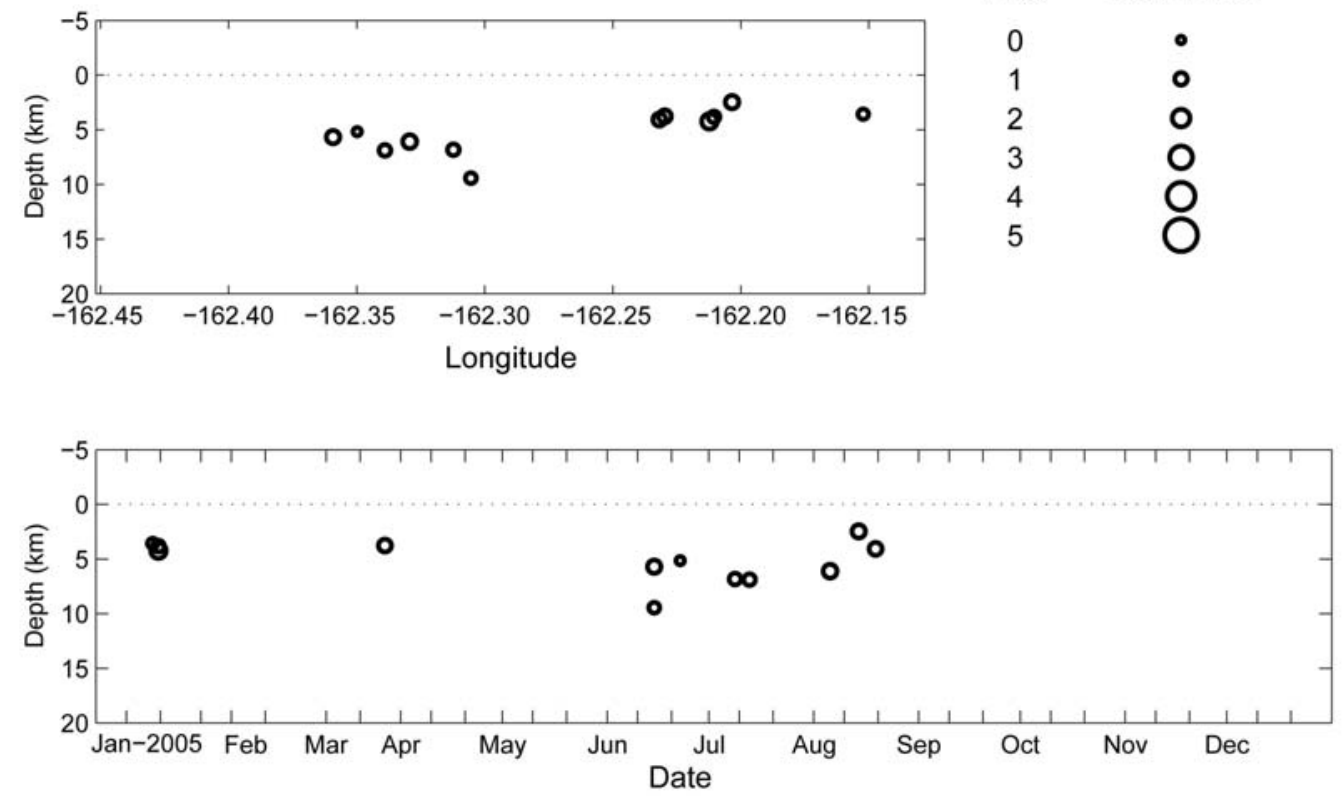

Figure A16. This summary plot shows 12 earthquakes located near Mount Dutton in 2005. Open circles show hypocenter locations shallower than $20 \mathrm{~km}$ and open triangles show hypocenters with depths of $20 \mathrm{~km}$ and deeper. Hypocenter symbols are scaled with magnitude. Seismograph stations are shown by open squares and labeled by station code. Solid triangles are used to show volcanic centers and solid squares are used to show other points of interest. See Appendix B for station information. 
Unimak Island Seismicity
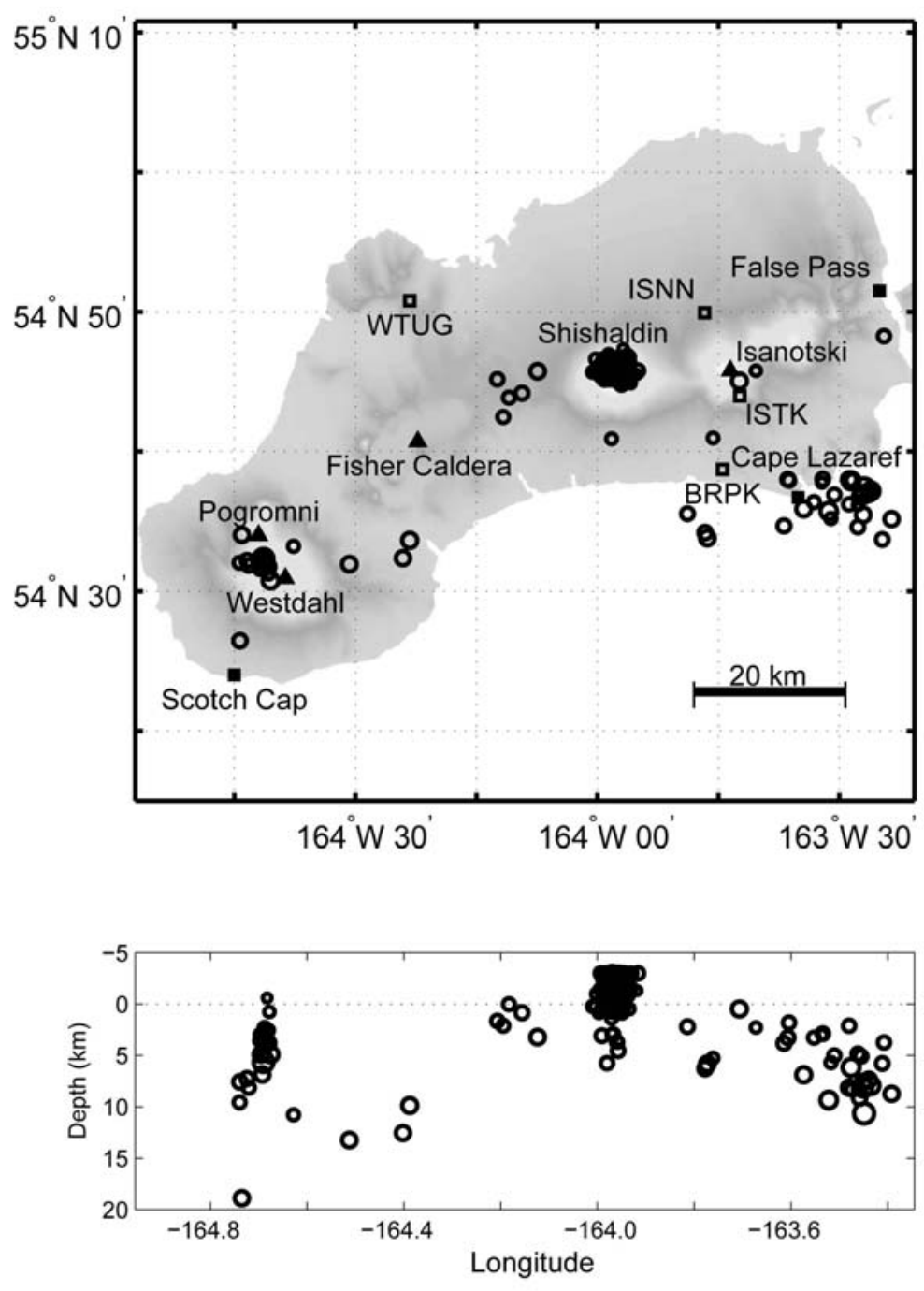

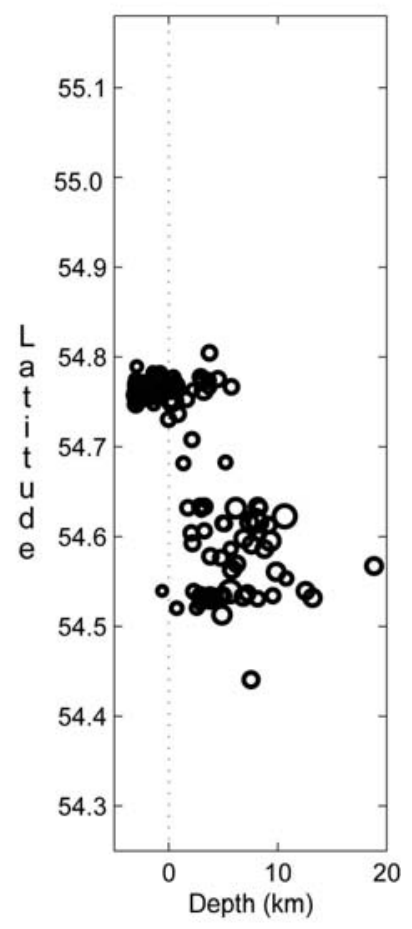

Mag. Symb. Size

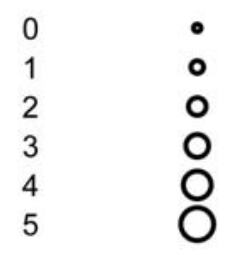

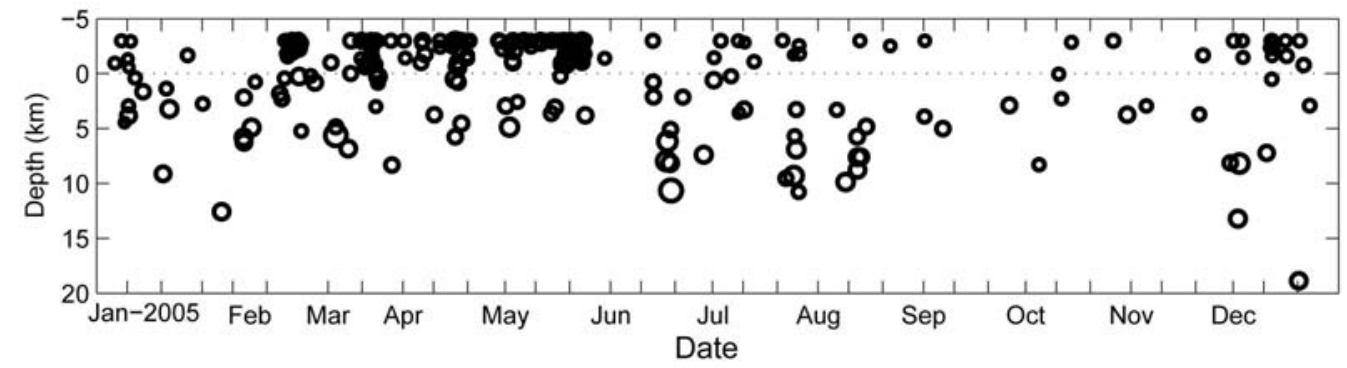

Figure A17. Summary plots of 264 earthquakes located near Unimak Island in 2005. Open circles show hypocenter locations shallower than $20 \mathrm{~km}$ and open triangles show hypocenters with depths of $20 \mathrm{~km}$ and deeper. Hypocenter symbols are scaled with magnitude. Seismograph stations are shown by open squares and labeled by station code. Solid triangles are used to show volcanic centers and solid squares are used to show other points of interest. See Appendix B for station information. 
Shishaldin Volcano Seismicity
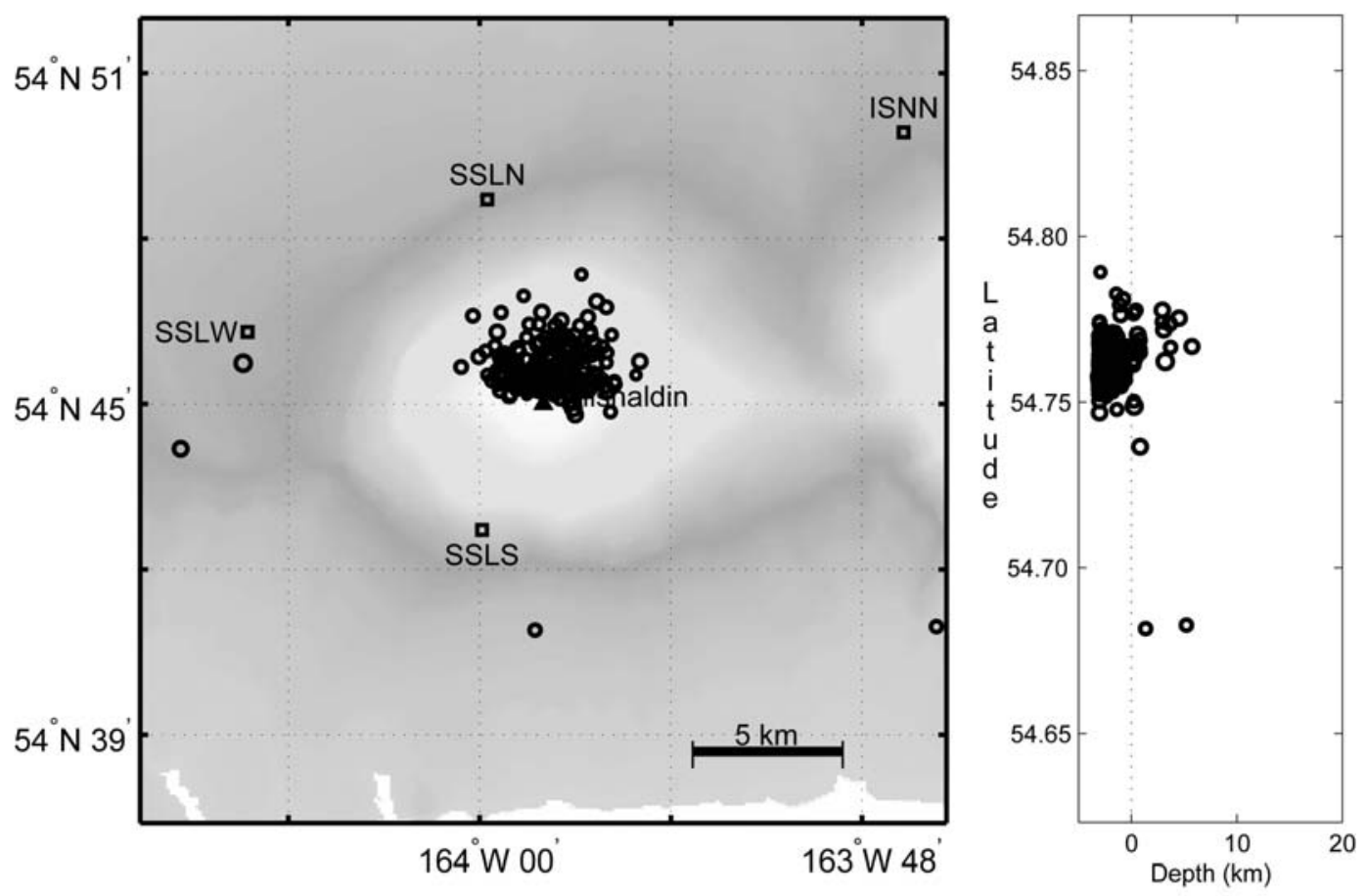

Mag. Symb. Size
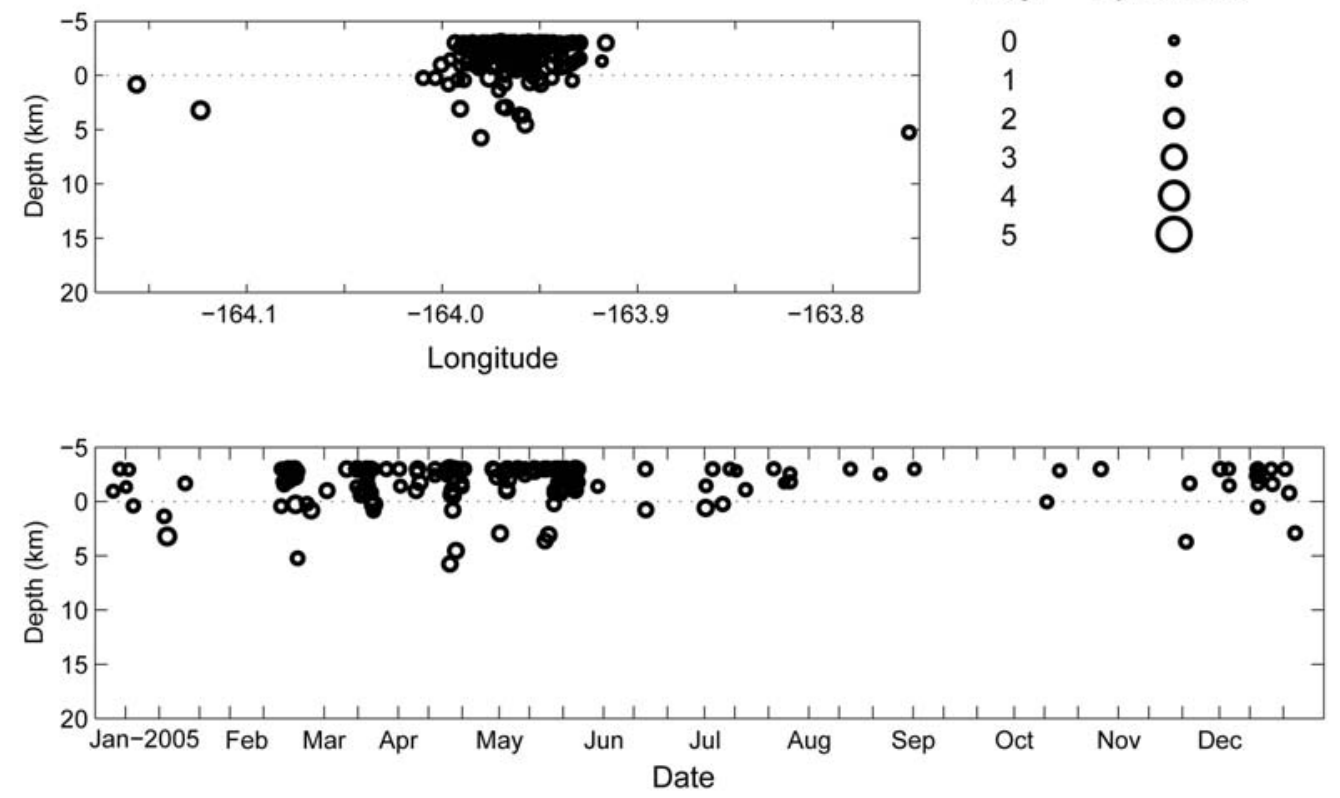

Figure A18. Summary plots of 203 earthquakes located near Shishaldin Volcano in 2005. Open circles show hypocenter locations shallower than $20 \mathrm{~km}$ and open triangles show hypocenters with depths of $20 \mathrm{~km}$ and deeper. Hypocenter symbols are scaled with magnitude. Seismograph stations are shown by open squares and labeled by station code. Solid triangles are used to show volcanic centers and solid squares are used to show other points of interest. See Appendix B for station information. 

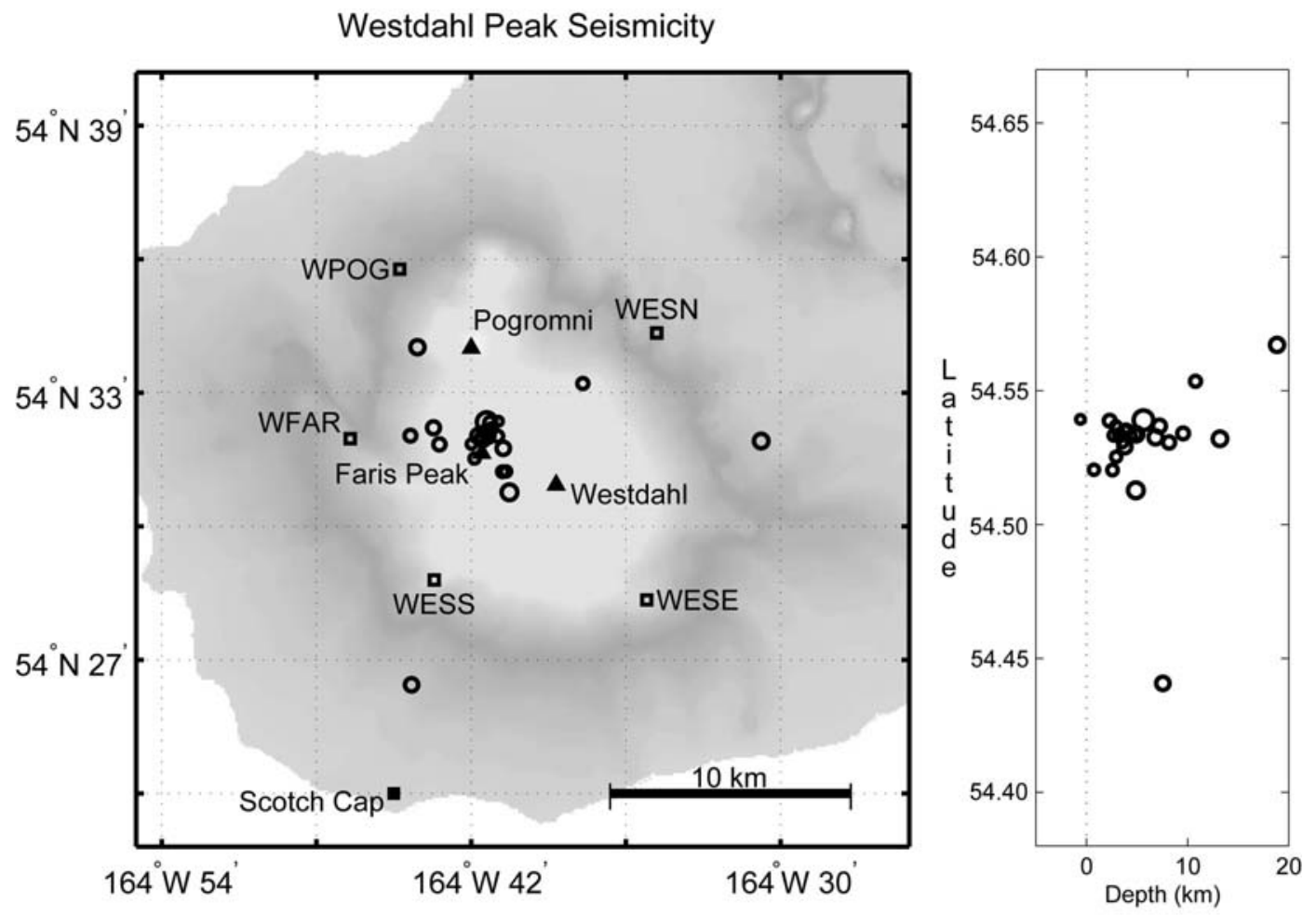

Mag. Symb. Size
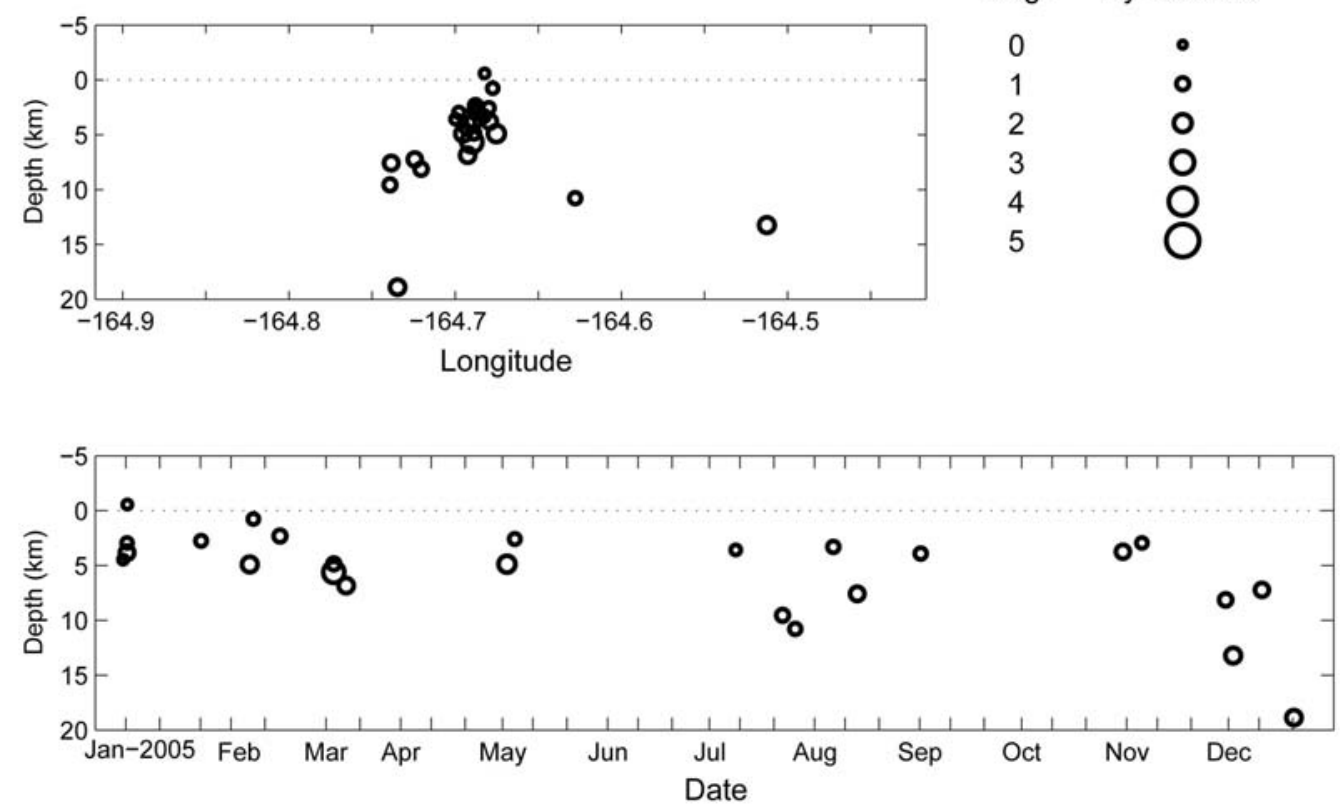

Figure A19. Summary plots of 25 earthquakes located near Westdahl Peak in 2005. Open circles show hypocenter locations shallower than $20 \mathrm{~km}$ and open triangles show hypocenters with depths of $20 \mathrm{~km}$ and deeper. Hypocenter symbols are scaled with magnitude. Seismograph stations are shown by open squares and labeled by station code. Solid triangles are used to show volcanic centers and solid squares are used to show other points of interest. See Appendix B for station information. 

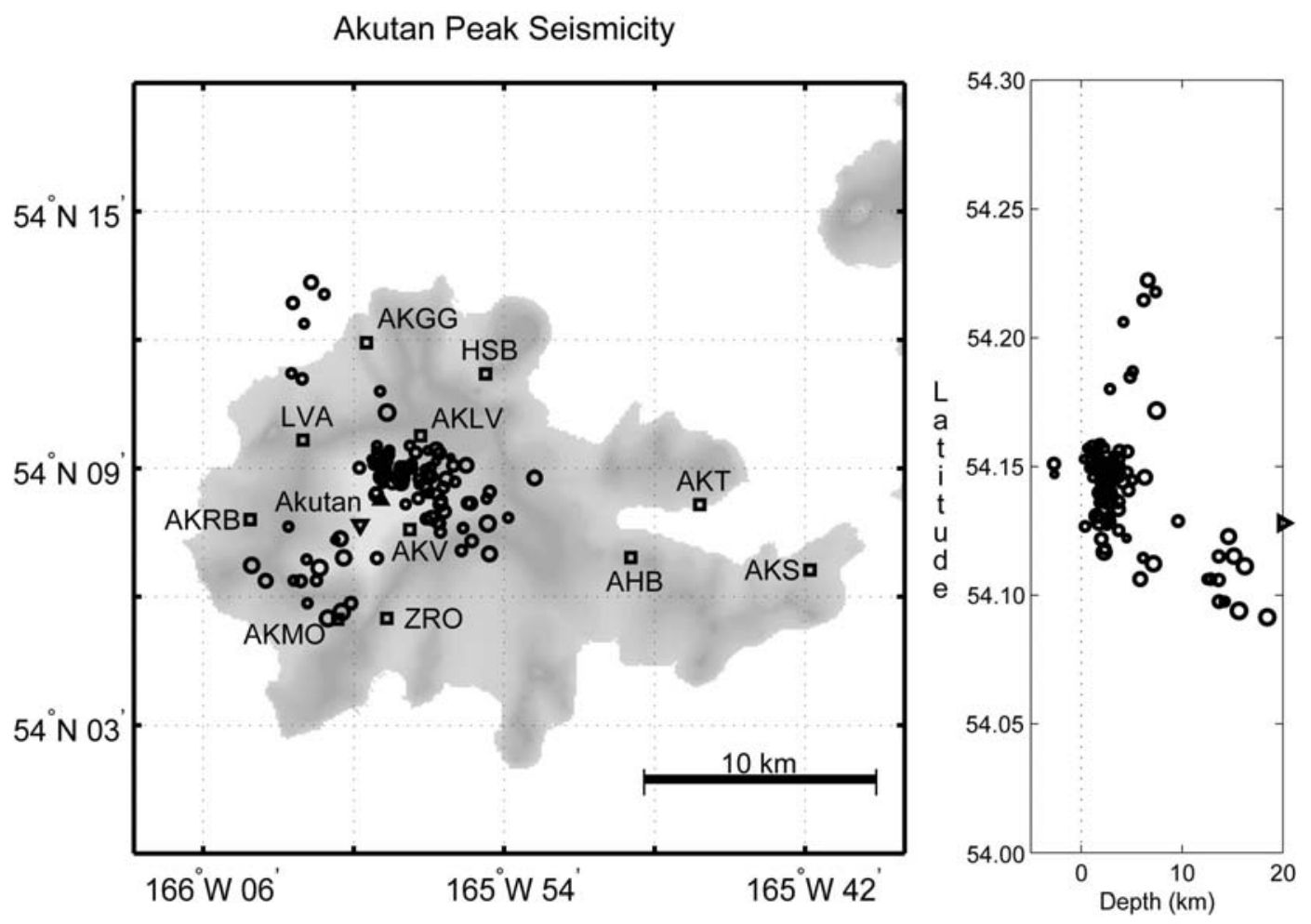

Mag. Symb. Size
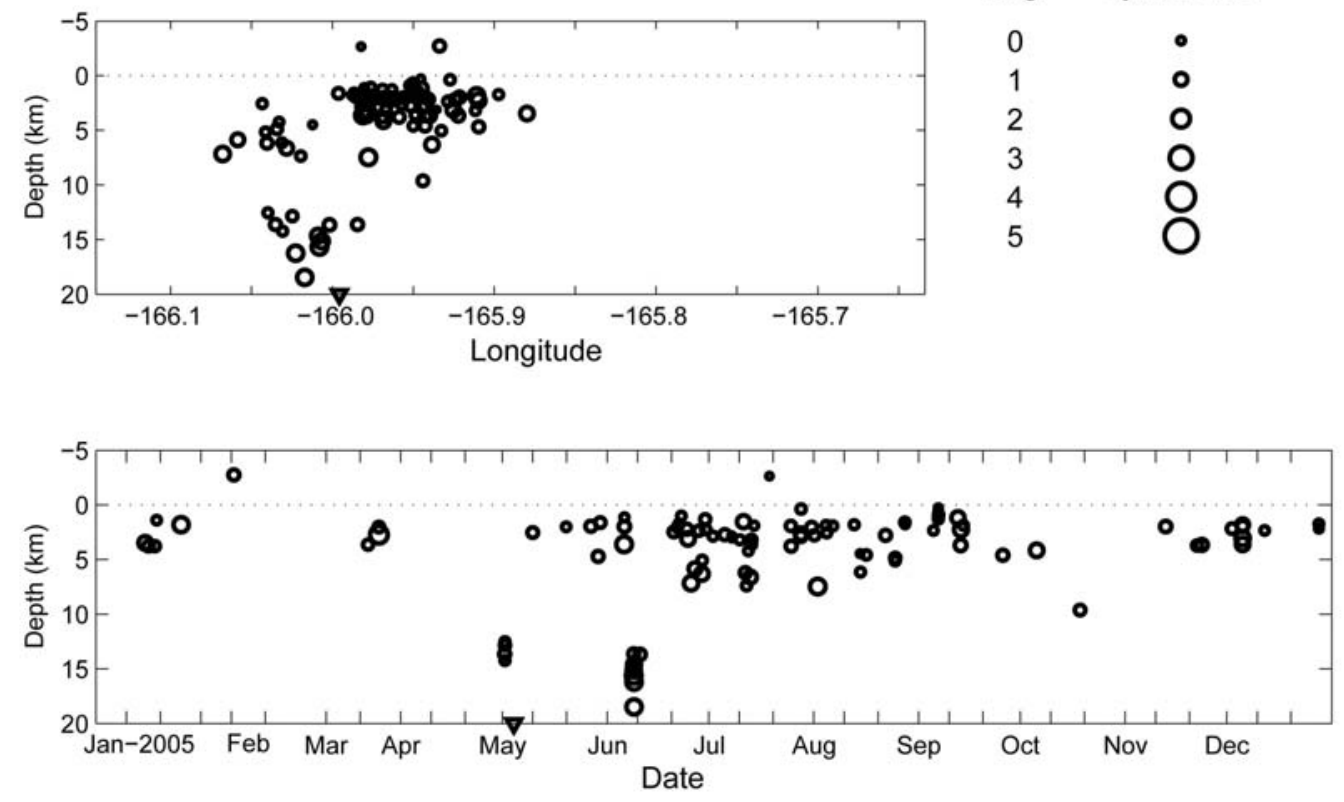

Figure A20. Summary plots of 100 earthquakes located near Akutan Peak in 2005. Open circles show hypocenter locations shallower than $20 \mathrm{~km}$ and open triangles show hypocenters with depths of $20 \mathrm{~km}$ and deeper. Hypocenter symbols are scaled with magnitude. Seismograph stations are shown by open squares and labeled by station code. Solid triangles are used to show volcanic centers and solid squares are used to show other points of interest. See Appendix B for station information. 
Makushin Volcano Seismicity
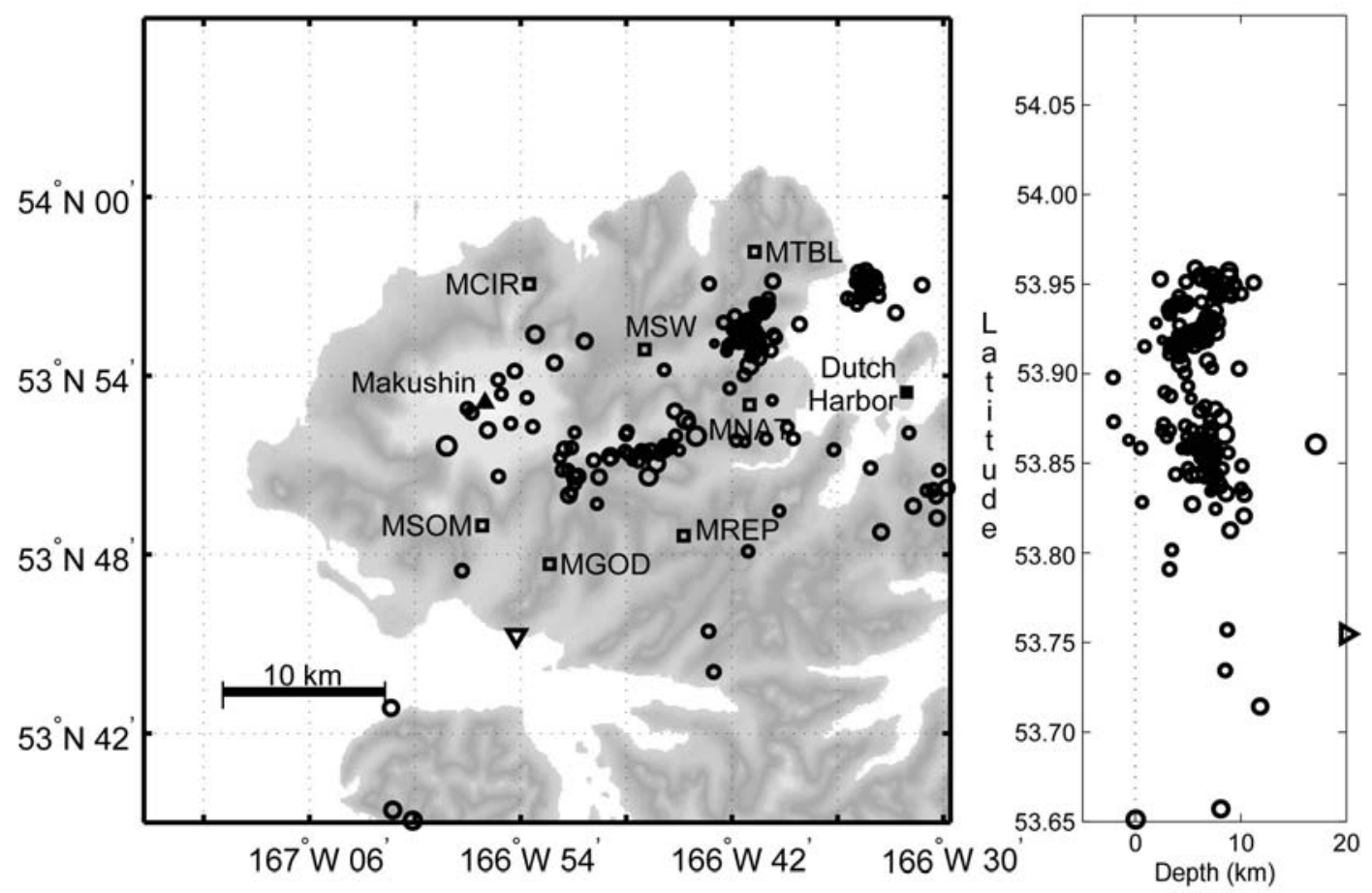

Mag. Symb. Size
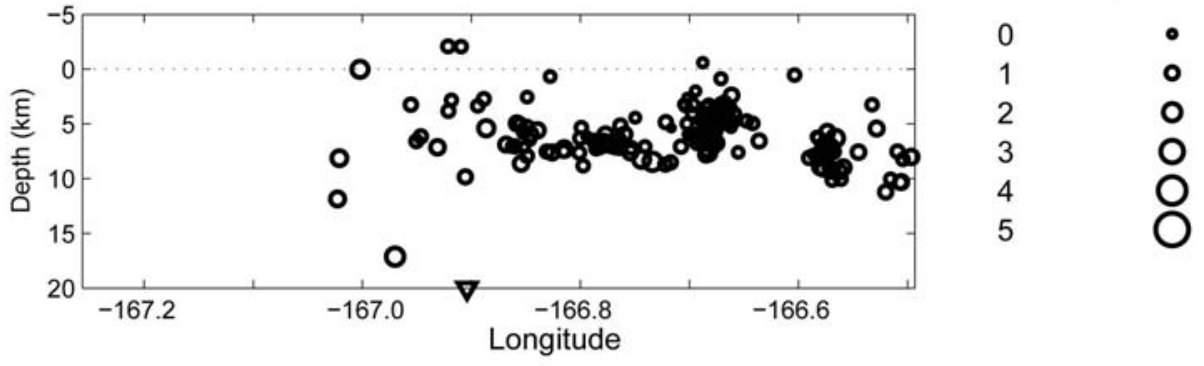

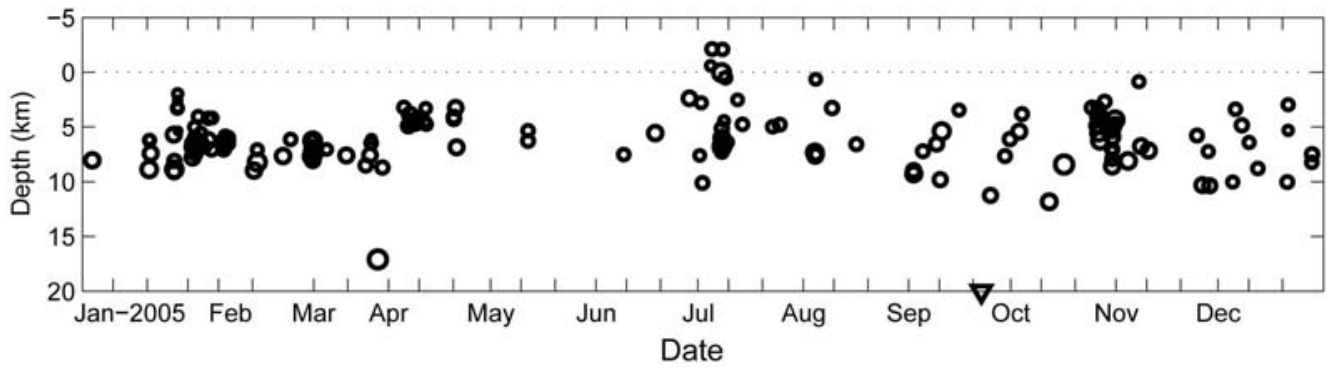

Figure A21. Summary plots of 175 earthquakes located near Makushin Volcano in 2005. Open circles show hypocenter locations shallower than $20 \mathrm{~km}$ and open triangles show hypocenters with depths of $20 \mathrm{~km}$ and deeper. Hypocenter symbols are scaled with magnitude. Seismograph stations are shown by open squares and labeled by station code. Solid triangles are used to show volcanic centers and solid squares are used to show other points of interest. See Appendix B for station information. 

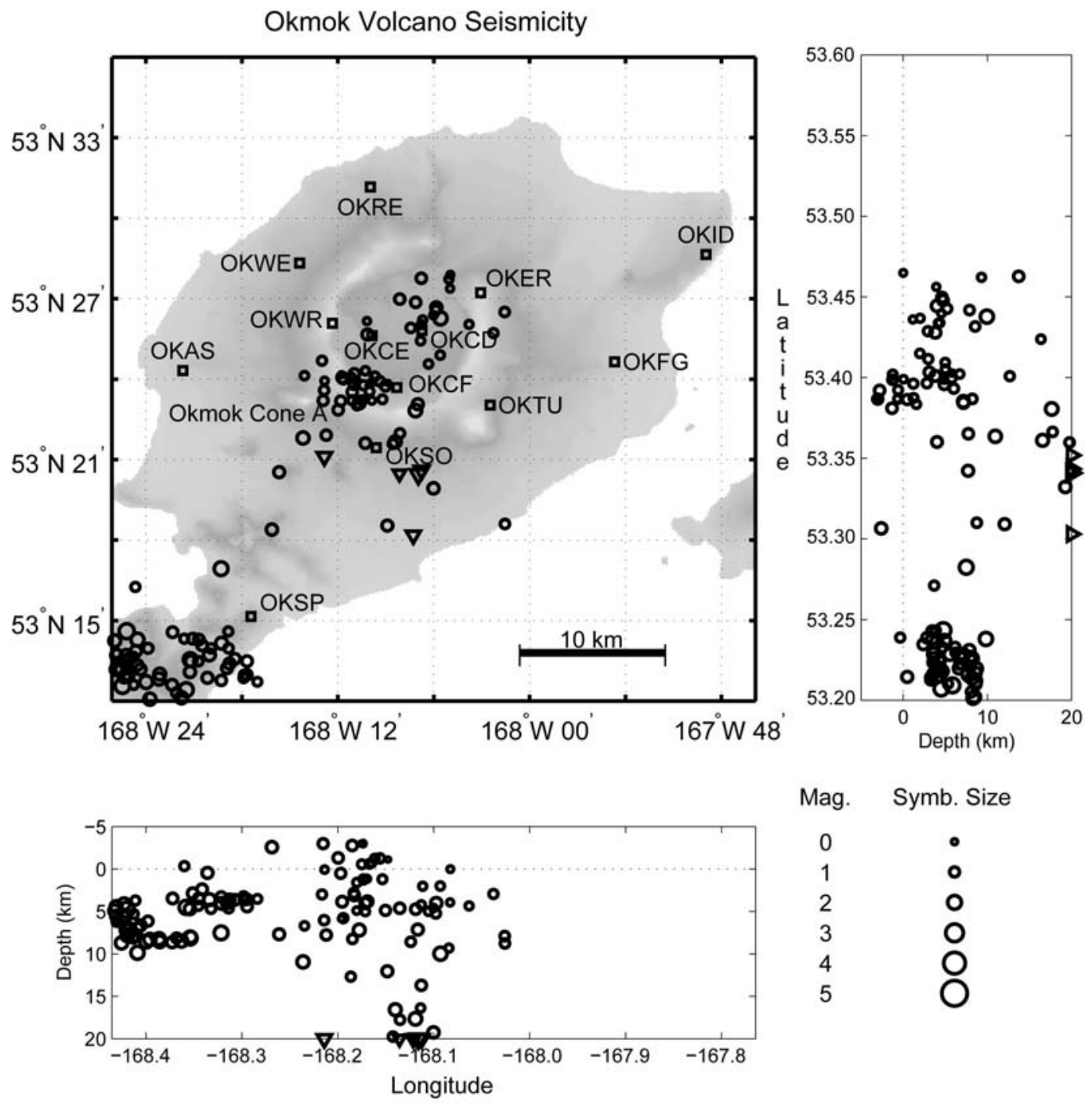

Mag. Symb. Size

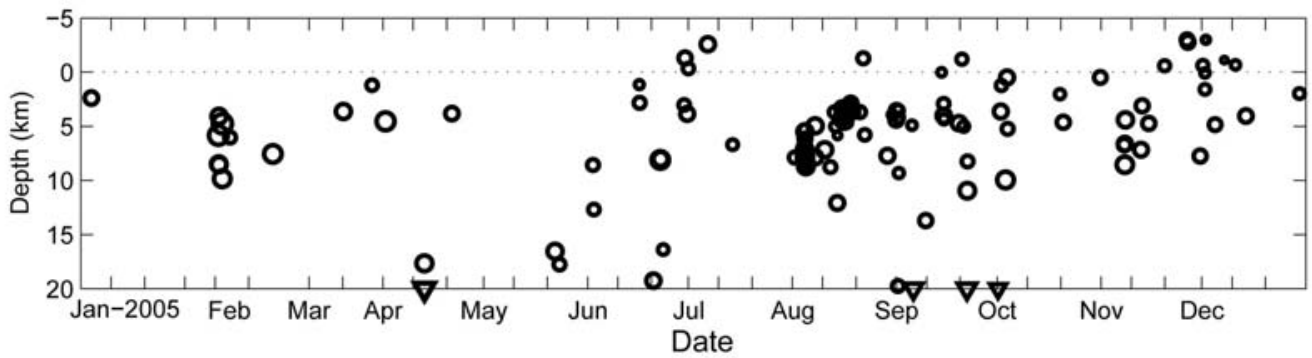

Figure A22. Summary plots of 123 earthquakes located near Okmok Caldera in 2005. Open circles show hypocenter locations shallower than $20 \mathrm{~km}$ and open triangles show hypocenters with depths of $20 \mathrm{~km}$ and deeper. Hypocenter symbols are scaled with magnitude. Seismograph stations are shown by open squares and labeled by station code. Solid triangles are used to show volcanic centers and solid squares are used to show other points of interest. See Appendix B for station information. 
Korovin Volcano Seismicity
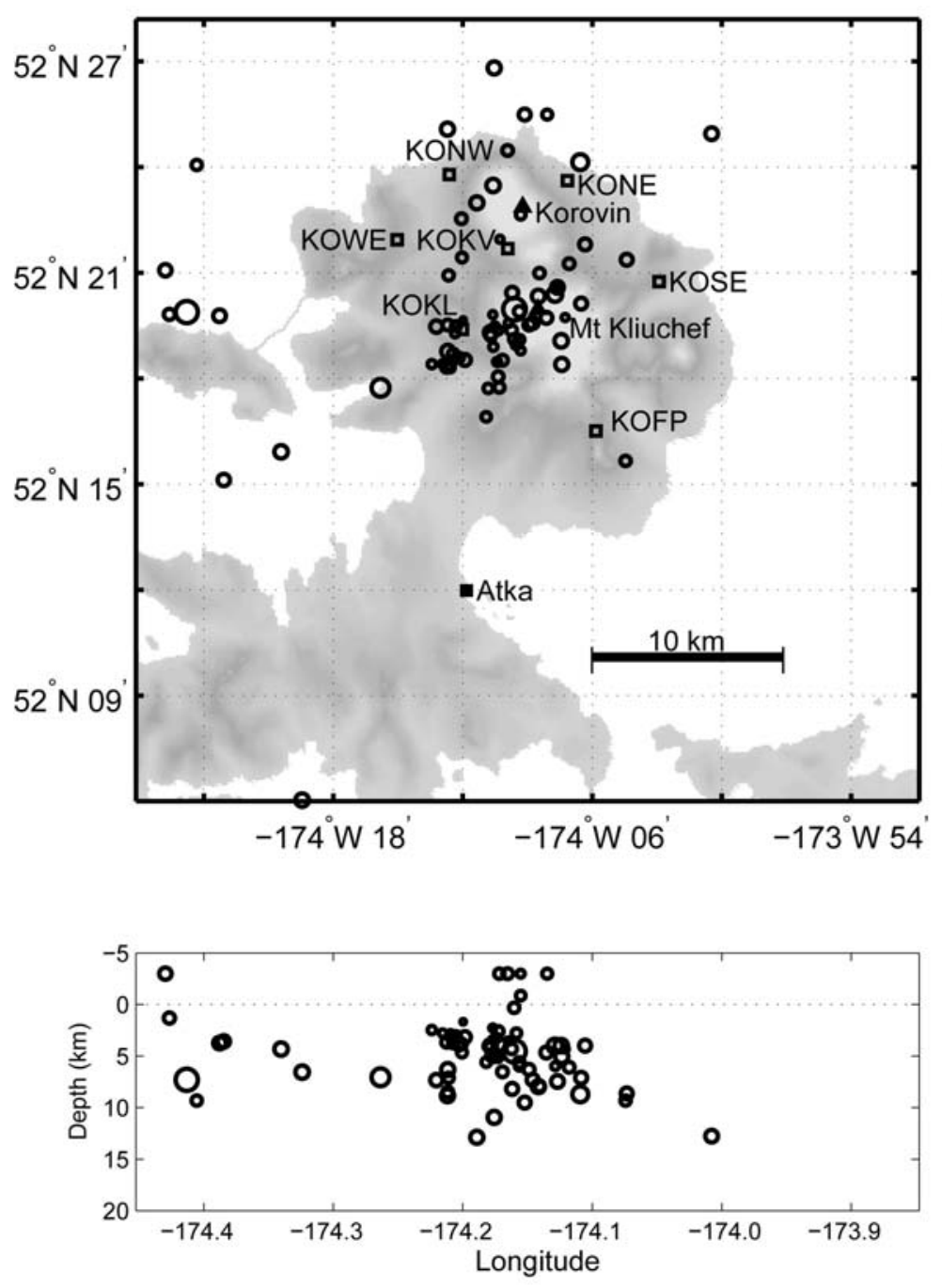

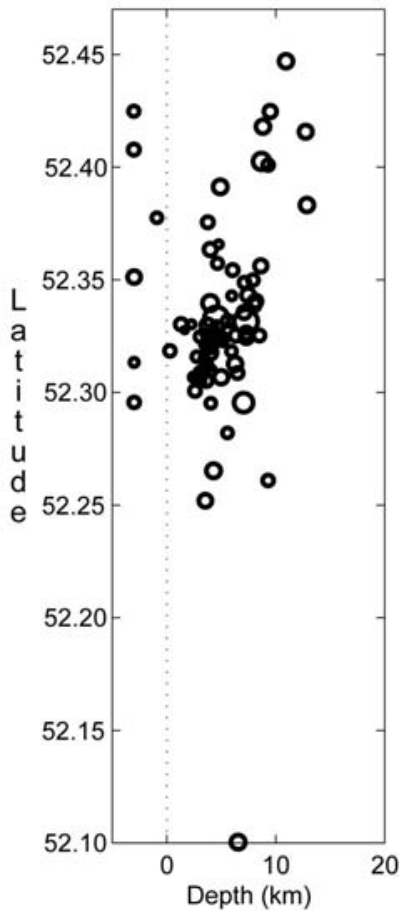

Mag. Symb. Size

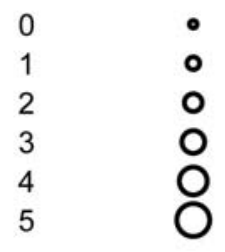

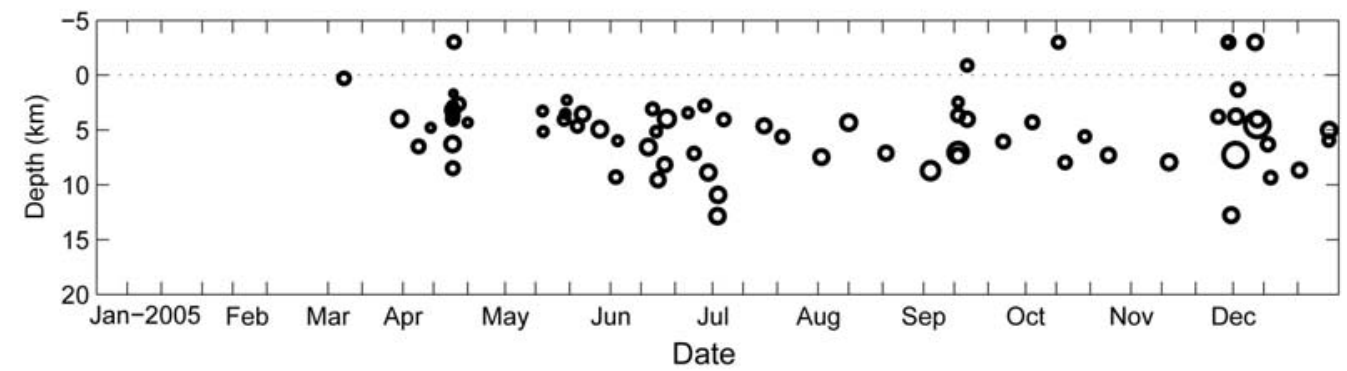

Figure A23. Summary plots of 74 earthquakes located near Korovin Volcano in 2005. Open circles show hypocenter locations shallower than $20 \mathrm{~km}$ and open triangles show hypocenters with depths of $20 \mathrm{~km}$ and deeper. Hypocenter symbols are scaled with magnitude. Seismograph stations are shown by open squares and labeled by station code. Solid triangles are used to show volcanic centers and solid squares are used to show other points of interest. See Appendix B for station information. 

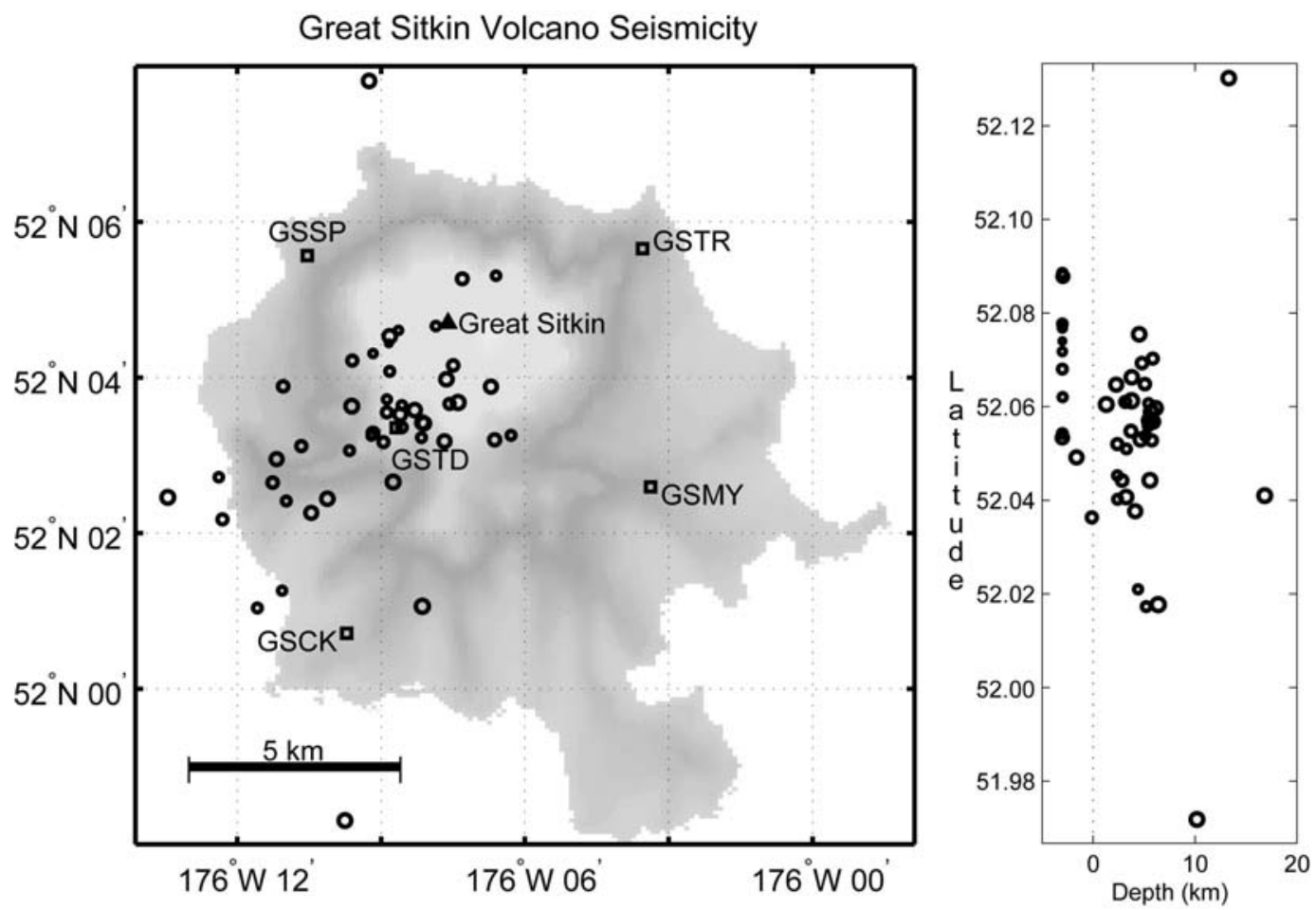

Mag. Symb. Size
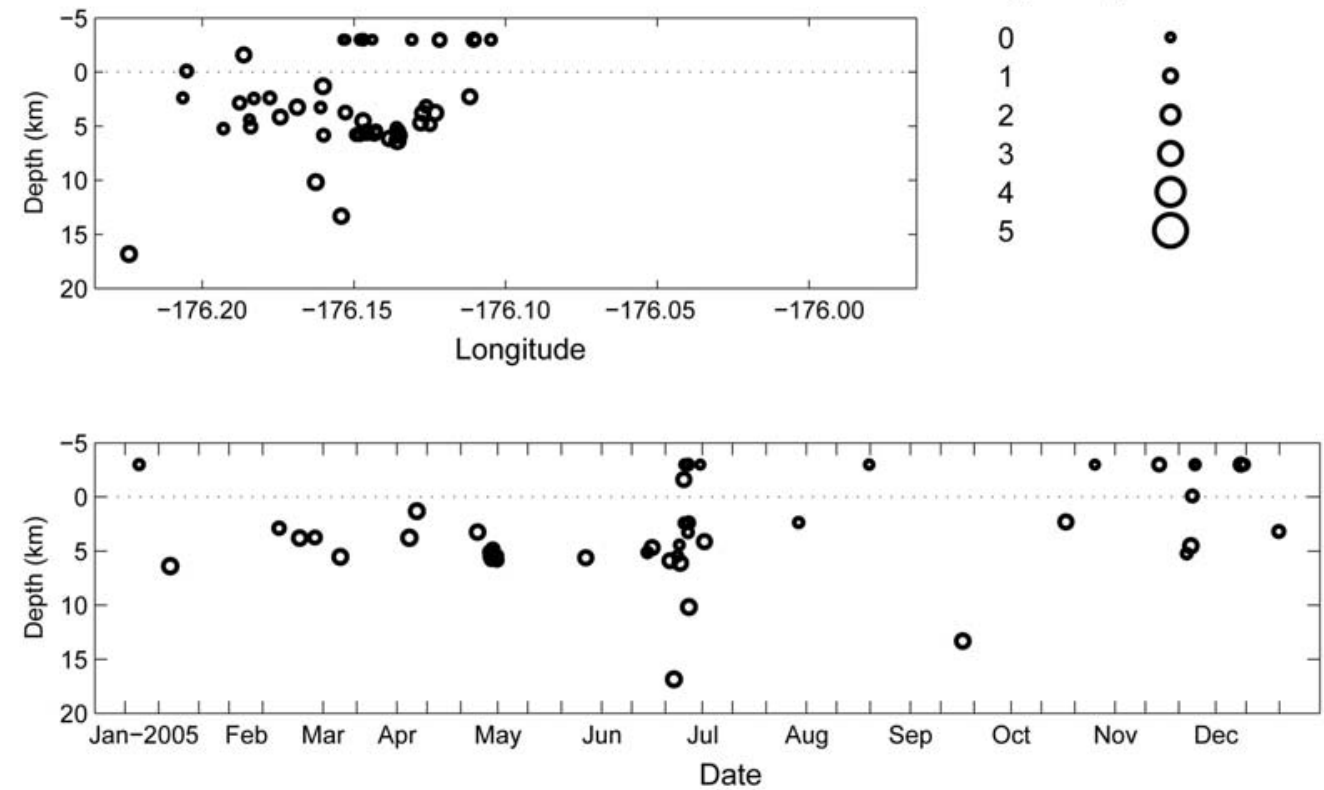

Figure A24. Summary plots of 47 earthquakes located near Great Sitkin Volcano in 2005. Open circles show hypocenter locations shallower than $20 \mathrm{~km}$ and open triangles show hypocenters with depths of $20 \mathrm{~km}$ and deeper. Hypocenter symbols are scaled with magnitude. Seismograph stations are shown by open squares and labeled by station code. Solid triangles are used to show volcanic centers and solid squares are used to show other points of interest. See Appendix B for station information. 

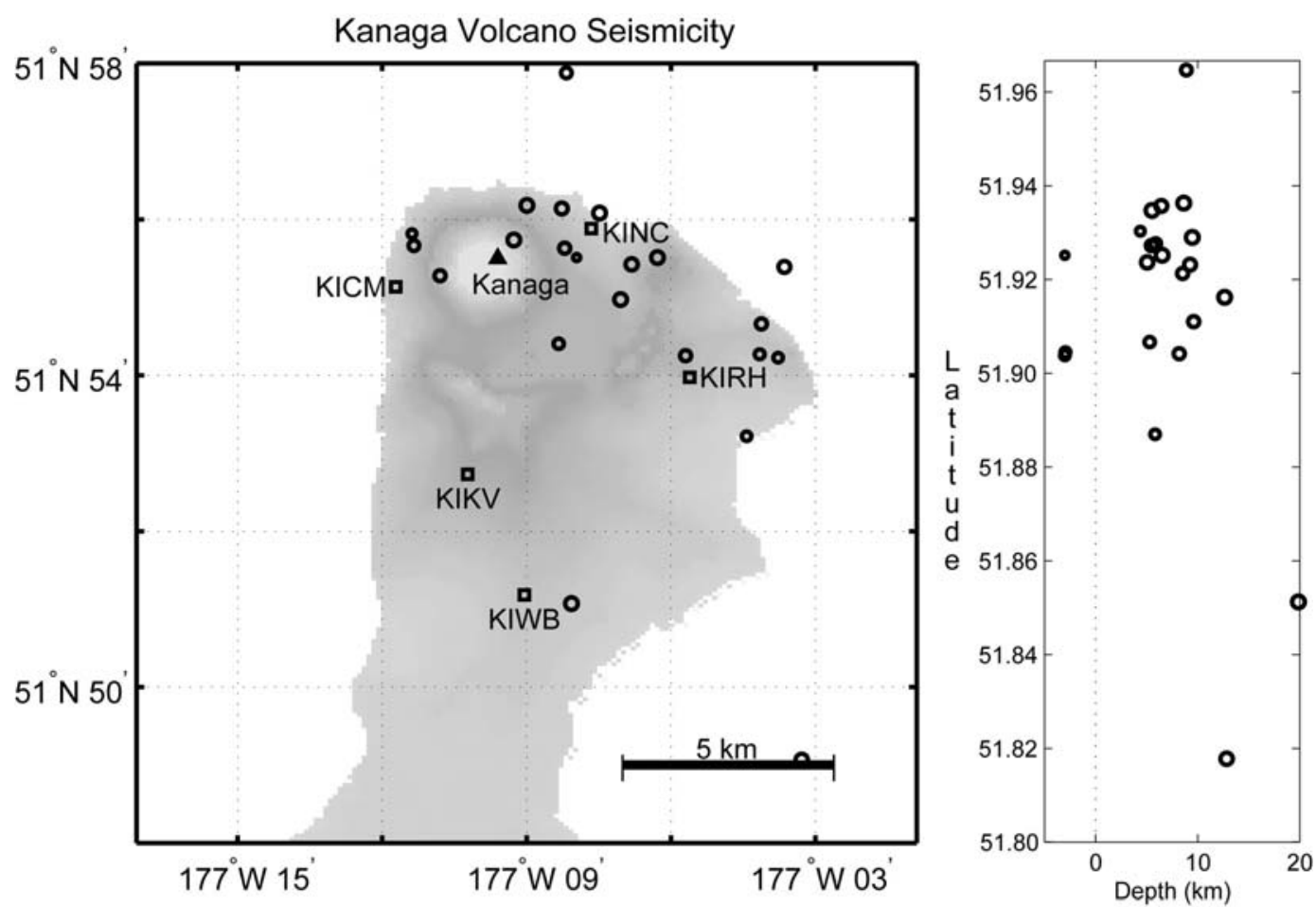

Mag. Symb. Size
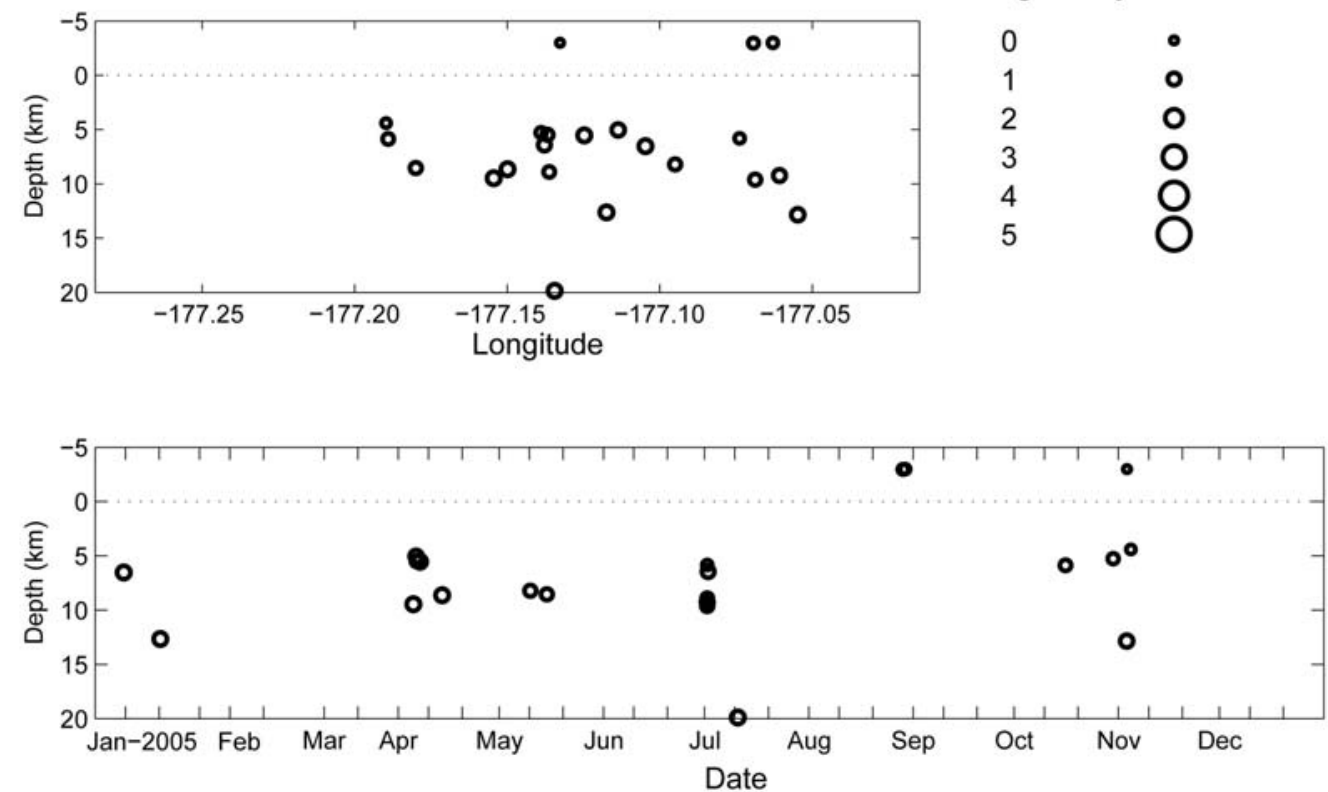

Figure A25. Summary plots of 22 earthquakes located near Kanaga Volcano in 2005. Open circles show hypocenter locations shallower than $20 \mathrm{~km}$ and open triangles show hypocenters with depths of $20 \mathrm{~km}$ and deeper. Hypocenter symbols are scaled with magnitude. Seismograph stations are shown by open squares and labeled by station code. Solid triangles are used to show volcanic centers and solid squares are used to show other points of interest. See Appendix B for station information. 
Tanaga Volcano Seismicity

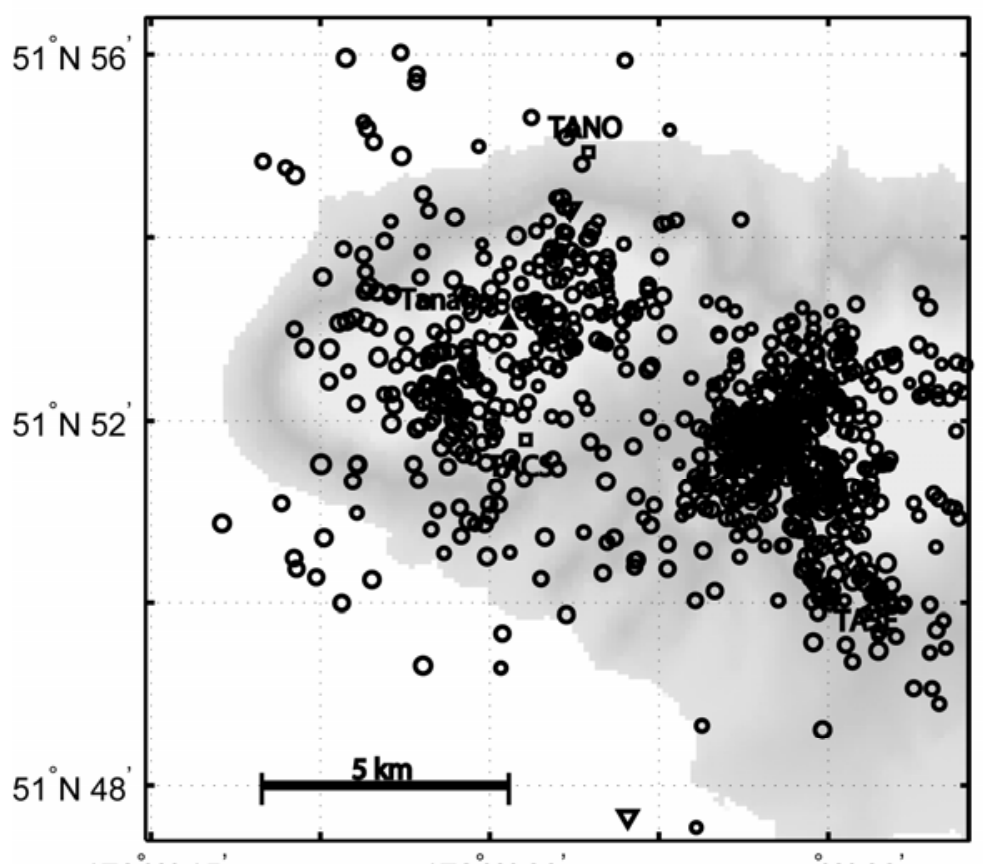

$178 \mathrm{~W} 03$

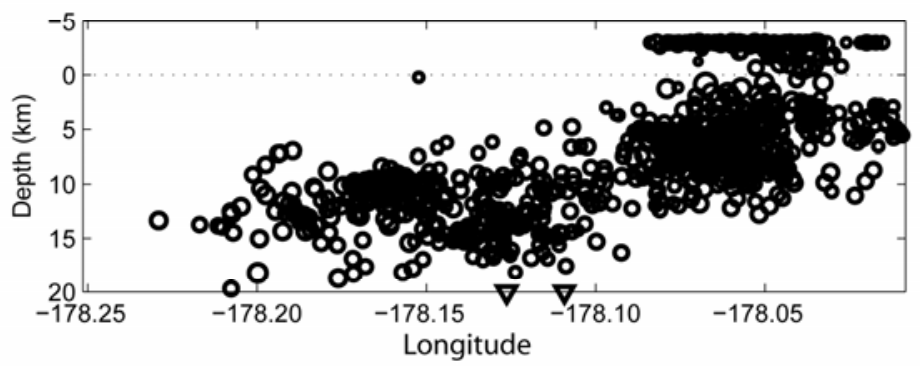

Mag. Symb. Size

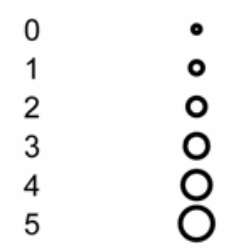

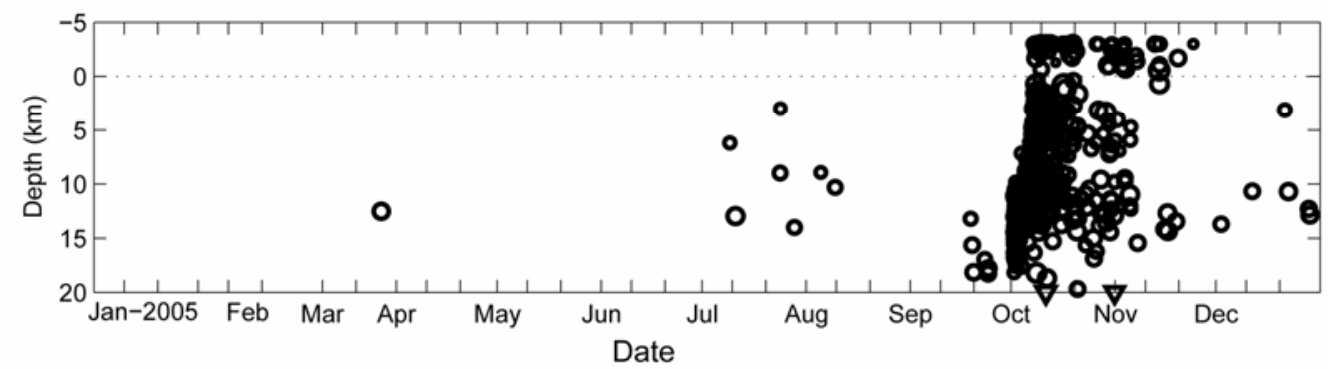

Figure A26. Summary plots of 855 earthquake located near Tanaga Volcano in 2005. Open circles show hypocenter locations shallower than $20 \mathrm{~km}$ and open triangles show hypocenters with depths of $20 \mathrm{~km}$ and deeper. Hypocenter symbols are scaled with magnitude. Seismograph stations are shown by open squares and labeled by station code. Solid triangles are used to show volcanic centers and solid squares are used to show other points of interest. See Appendix B for station information. 
Gareloi Volcano Seismicity
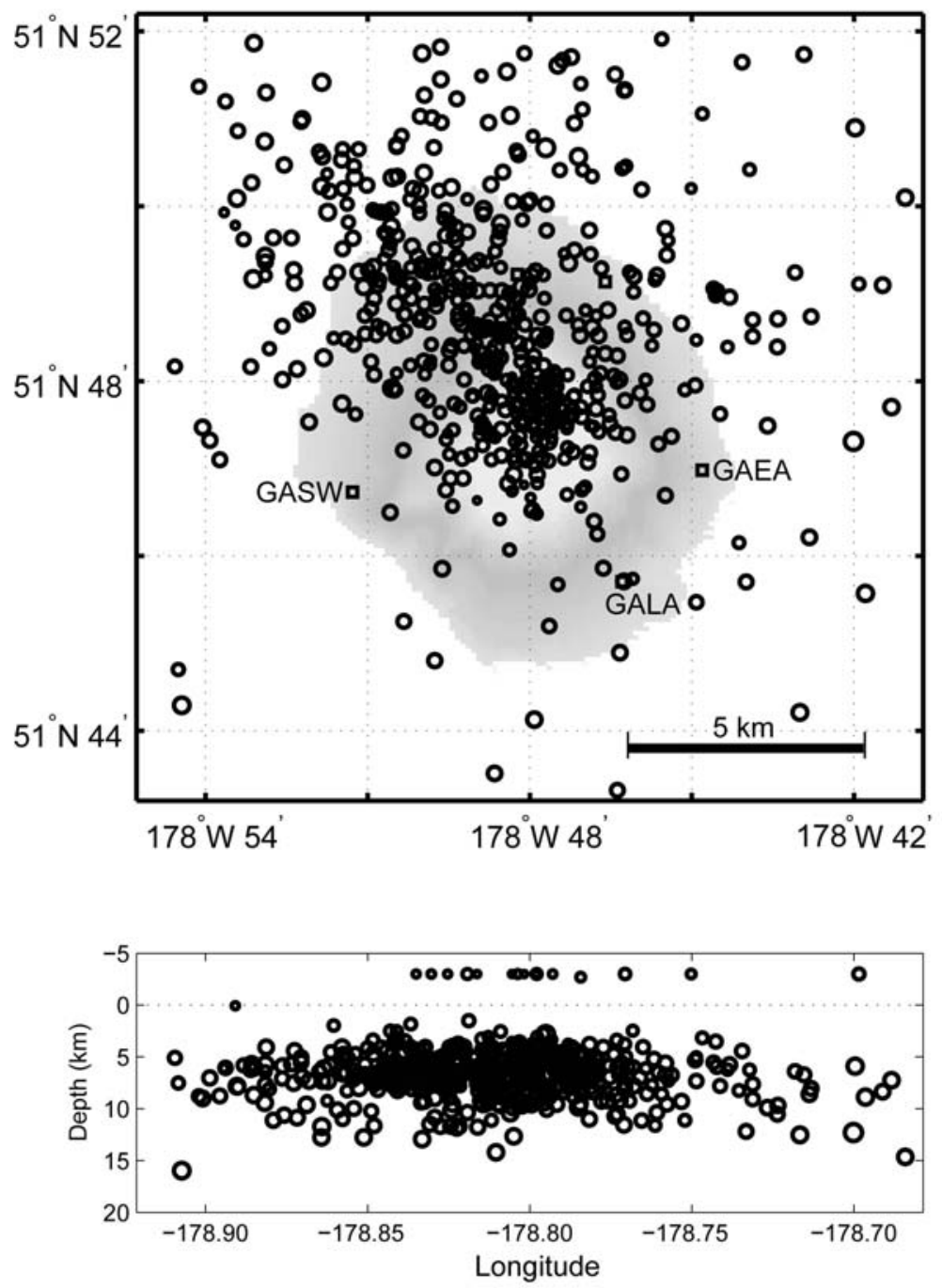

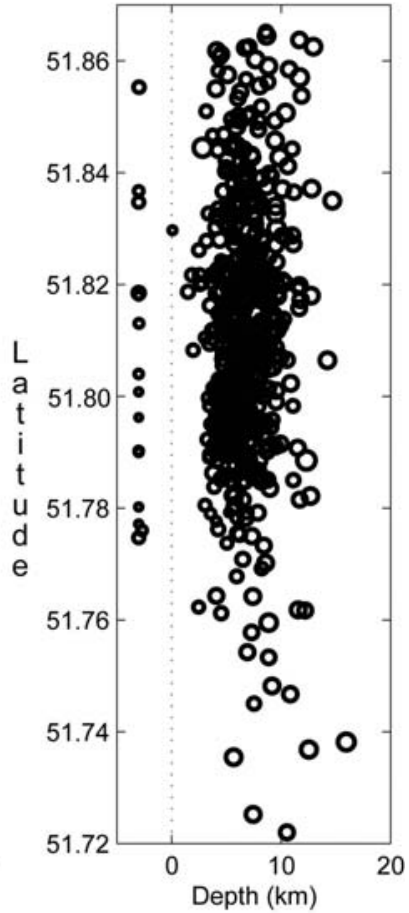

Mag. Symb. Size

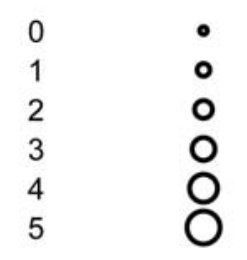

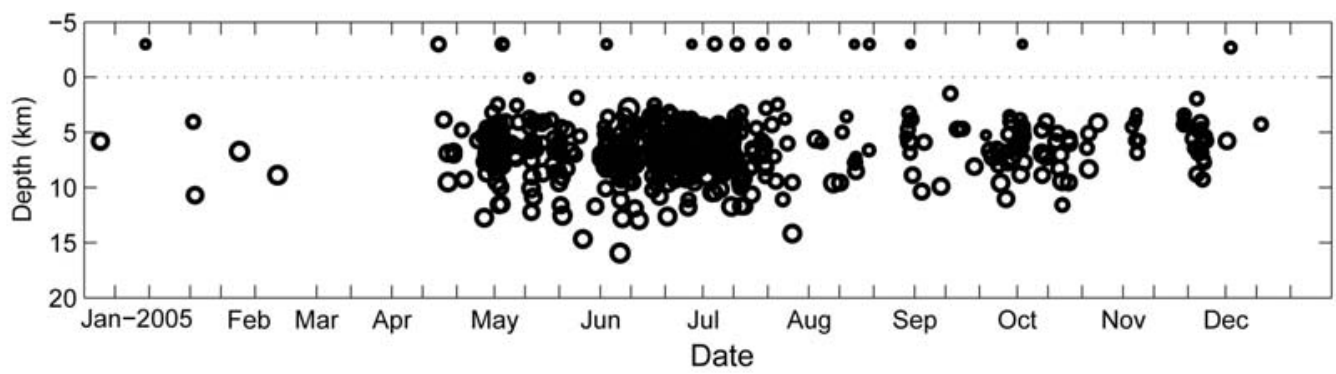

Figure A27. Summary plots of 547 earthquakes located near Mount Gareloi in 2005. Open circles show hypocenter locations shallower than $20 \mathrm{~km}$ and open triangles show hypocenters with depths of $20 \mathrm{~km}$ and deeper. Hypocenter symbols are scaled with magnitude. Seismograph stations are shown by open squares and labeled by station code. Solid triangles are used to show volcanic centers and solid squares are used to show other points of interest. See Appendix B for station information. 
Semisopochnoi Island Seismicity
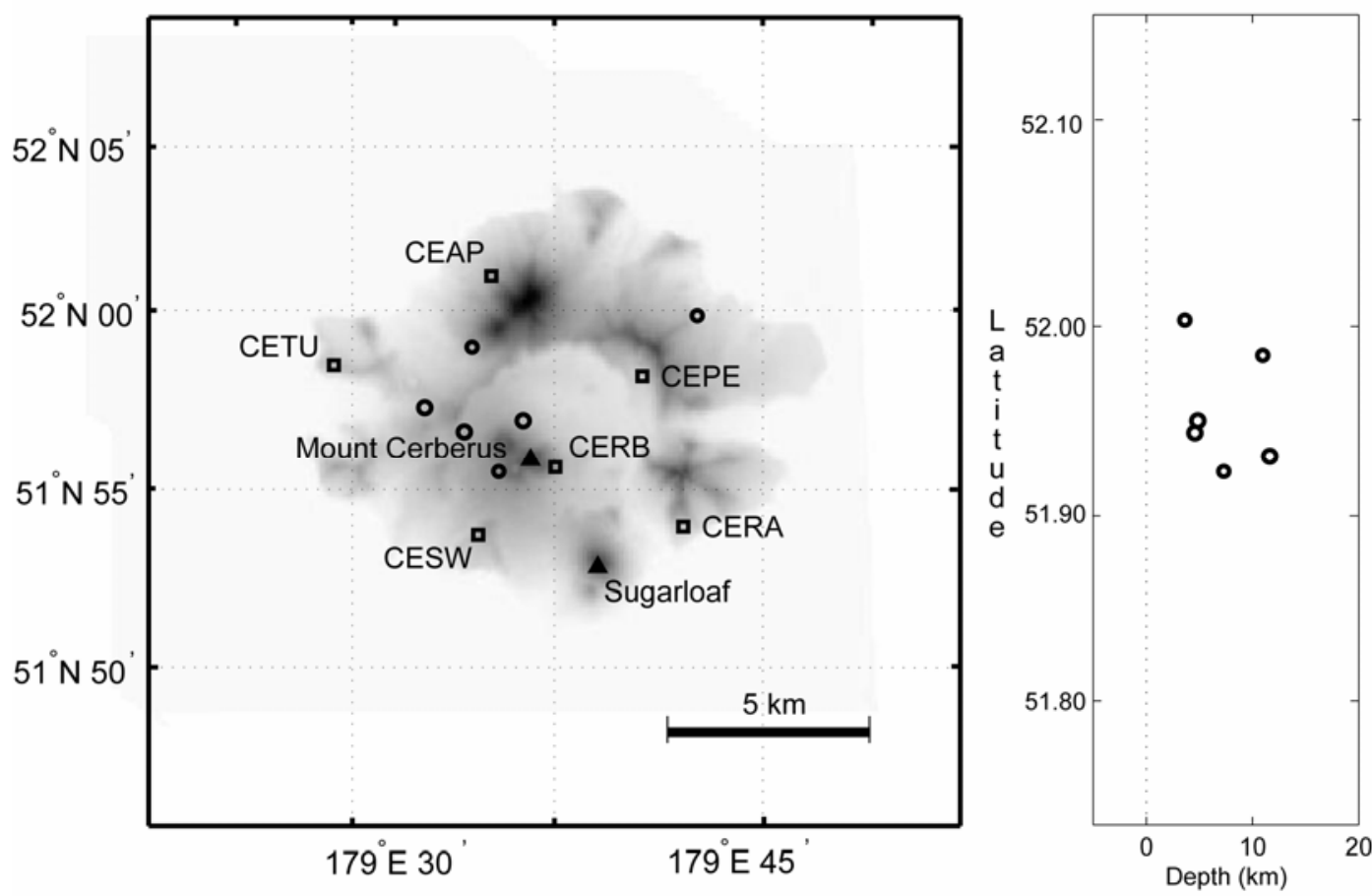

Mag. Symb. Size
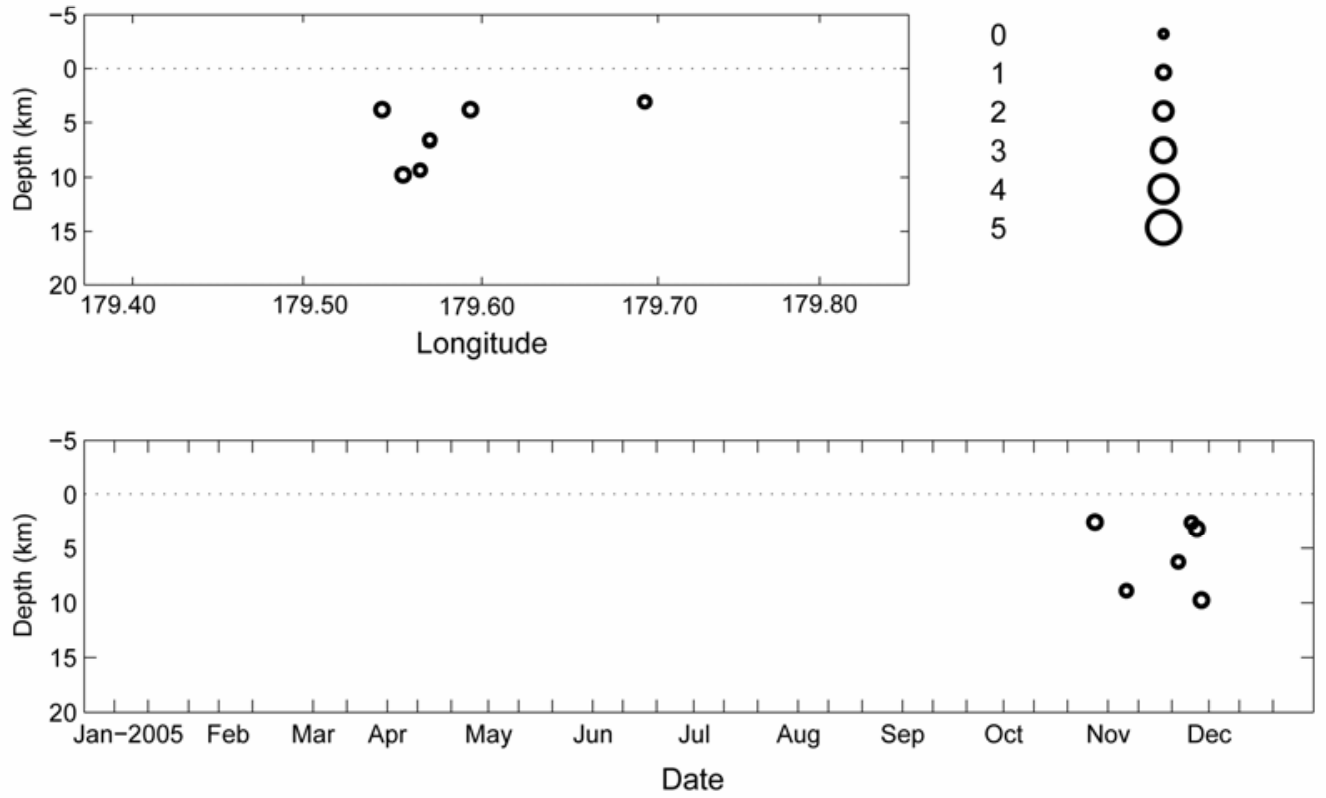

Figure A28. Summary plots of six earthquakes located on Semisopochnoi Island in 2005. Open circles show hypocenter locations shallower than $20 \mathrm{~km}$ and open triangles show hypocenters with depths of $20 \mathrm{~km}$ and deeper. Hypocenter symbols are scaled with magnitude. Seismograph stations are shown by open squares and labeled by station code. Solid triangles are used to show volcanic centers and solid squares are used to show other points of interest. See Appendix B for station information. 
Little Sitkin Island Seismicity
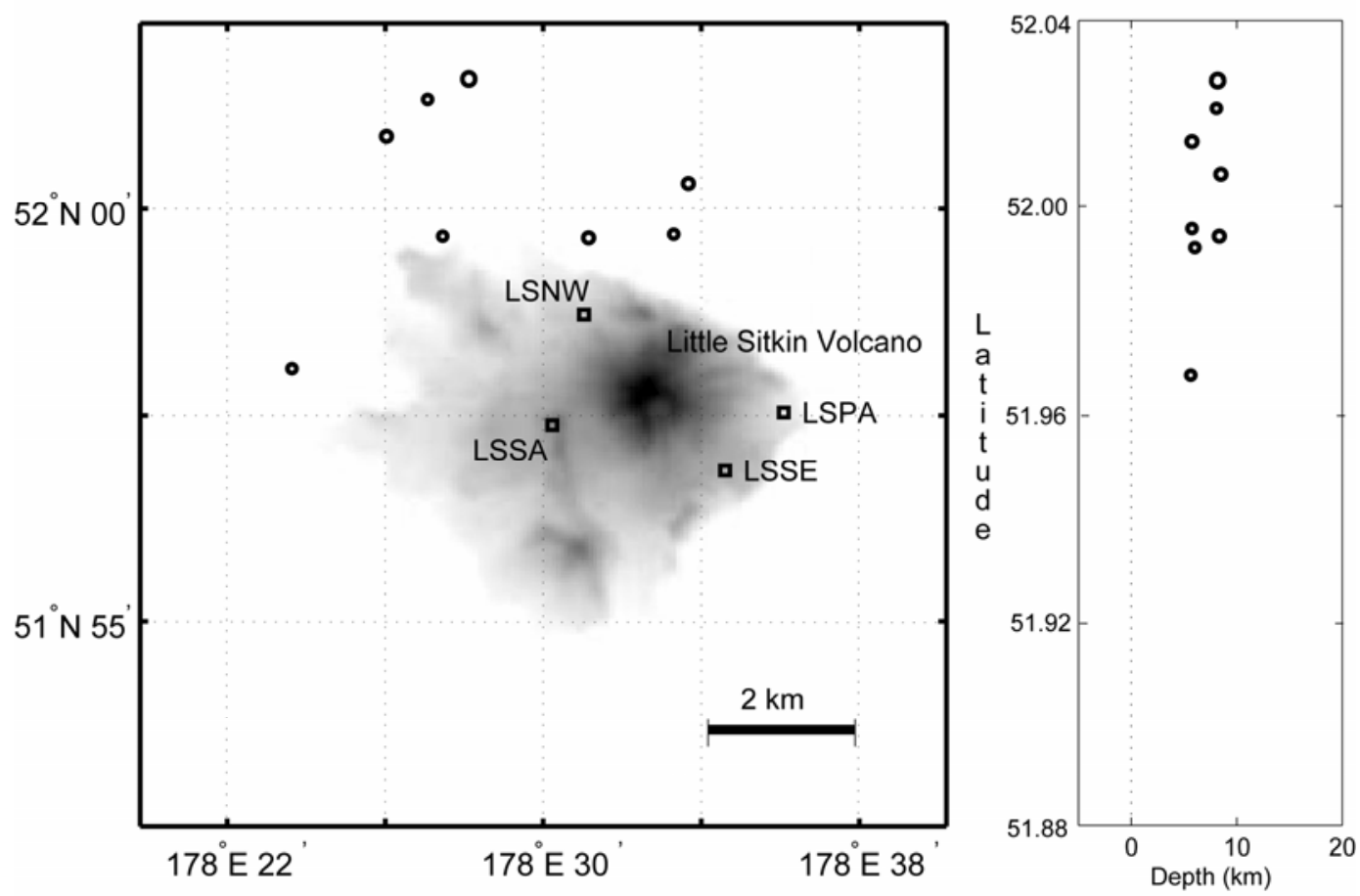

Mag. Symb. Size
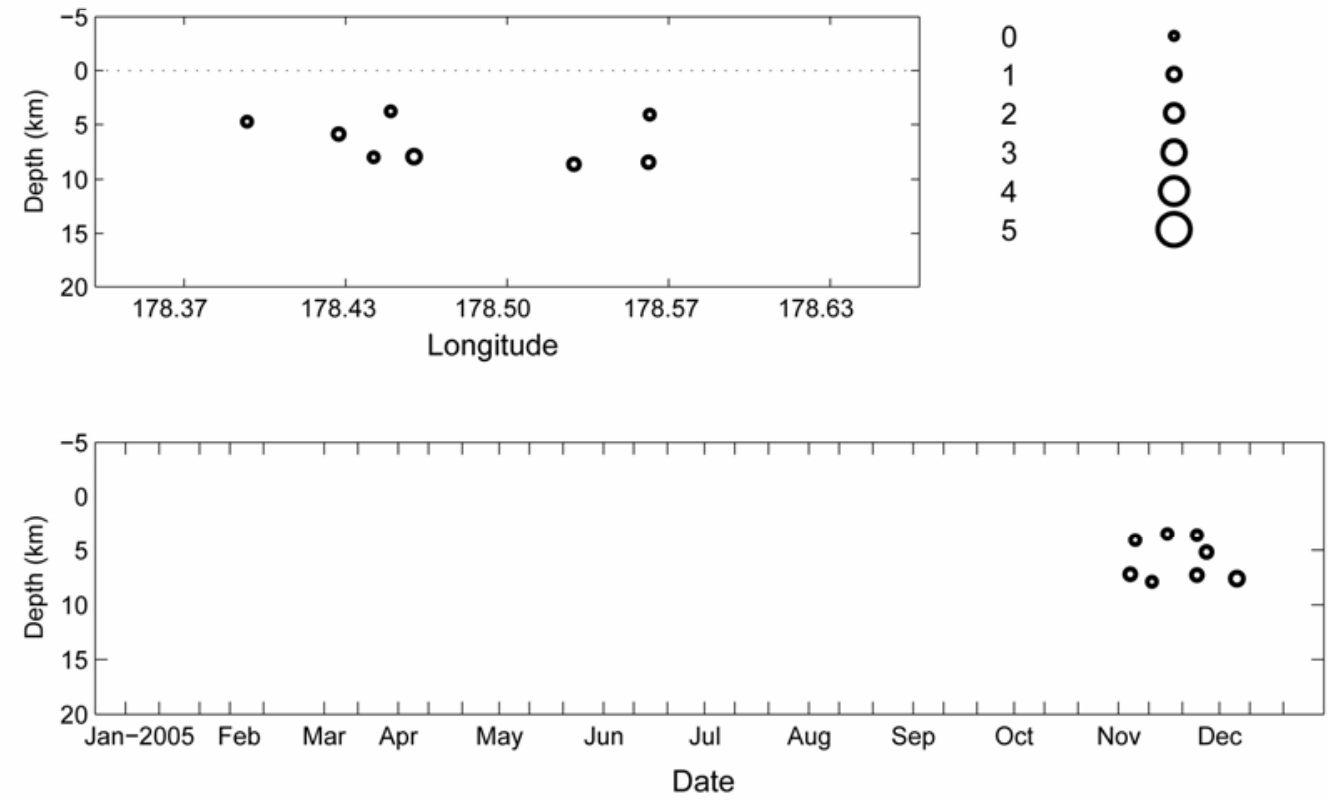

Figure A29. Summary plots of eight earthquakes located on Little Sitkin Island in 2005. Open circles show hypocenter locations shallower than $20 \mathrm{~km}$ and open triangles show hypocenters with depths of $20 \mathrm{~km}$ and deeper. Hypocenter symbols are scaled with magnitude. Seismograph stations are shown by open squares and labeled by station code. Solid triangles are used to show volcanic centers and solid squares are used to show other points of interest. See Appendix B for station information. 
Appendix B: Parameters for AVO seismograph stations (datum NAD27) in 2005

$\underline{\text { Station }}$ Latitude (N) Longitude (E) Elevation (m) $\underline{\text { Seismometer }}$ Station open date

\begin{tabular}{|c|c|c|c|c|c|}
\hline \multicolumn{6}{|c|}{ Akutan Peak subnet (11 stations - 23 components) } \\
\hline AHB & 5406.916 & -16548.943 & 447 & L4 & $1996 / 07 / 24$ \\
\hline $\mathrm{AKGG}^{3}$ & 5411.930 & -16559.495 & 326 & CMG-6TD & 2003/06/27 \\
\hline $\mathrm{AKLV}^{3}$ & 5409.762 & -16557.336 & 551 & CMG-6TD & 2003/07/02 \\
\hline AKMO & 3405.471 & -16600.634 & 277 & CMG-6TD & 2003/06/25 \\
\hline $\mathrm{AKRB}^{3}$ & 5407.803 & -16604.125 & 334 & CMG-6TD & 2003/06/29 \\
\hline $\mathrm{AKS}^{3}$ & 5406.624 & -16541.803 & 213 & L22 & $1996 / 07 / 24$ \\
\hline $\mathrm{AKT}^{3}$ & 5408.15 & -16546.2 & 12 & CMG-40T & 1996/03/18 \\
\hline AKV & 5407.571 & -16557.763 & 863 & L4 & 1996/07/24 \\
\hline HSB & 5411.205 & -16554.743 & 497 & L4 & $1996 / 07 / 24$ \\
\hline LVA & 5409.655 & -16602.025 & 457 & L4 & $1996 / 07 / 24$ \\
\hline ZRO & 5405.494 & -16558.678 & 446 & L4 & $1996 / 07 / 24$ \\
\hline
\end{tabular}

Aniakchak Crater subnet (6 stations - 8 components)

$\begin{array}{lrrrll}\text { ANNE } & 5654.763 & -15803.534 & 705 & \text { L4 } & 1997 / 07 / 18 \\ \text { ANNW } 5657.986 & -15812.895 & 816 & \text { L4 } & 1997 / 07 / 18 \\ \text { ANON }^{3} 5655.188 & -15810.293 & 445 & \text { L22 } & 2000 / 07 / 10 \\ \text { ANPB } & 5648.141 & -15816.847 & 658 & \text { L4 } & 1997 / 07 / 18 \\ \text { ANPK } & 5650.499 & -15807.572 & 972 & \text { L4 } & 1997 / 07 / 18 \\ \text { AZAC } & 5653.727 & -15813.841 & 1,057 & \text { L4 } & 2003 / 07 / 12\end{array}$

Augustine Volcano subnet (8 stations - 15 components)

\begin{tabular}{|c|c|c|c|c|c|}
\hline $\mathrm{AUE}^{3}$ & 5922.308 & -15322.504 & 168 & S13 & $1980 / 10 / 29$ \\
\hline AUH & 5921.833 & -15326.591 & 890 & S13 & 1978/12/01 \\
\hline $\mathrm{AUI}^{3}$ & 5920.11 & -15325.66 & 293 & S13 & 1978/04/06 \\
\hline AUL & 5922.937 & -15326.142 & 360 & S13 & 1980/10/29 \\
\hline $\mathrm{AUL}^{3}$ & 5922.937 & -15326.142 & 360 & CMG-40T & 1997/08/27 \\
\hline AUP & 5921.805 & -15325.210 & 1,033 & S13 & 1977/09/22 \\
\hline AUR & 5921.766 & -15325.876 & 1,225 & L4 & 1995/11/01 \\
\hline AUS & 5921.599 & -15325.840 & 1,226 & L4 & 1990/09/01 \\
\hline AUW & 5922.205 & -15328.249 & 276 & S13 & $1976 / 10 / 17$ \\
\hline \multicolumn{6}{|c|}{ Mount Dutton subnet (5 stations - 5 components) } \\
\hline BLDY & 5511.670 & -16247.018 & 259 & L4 & 1996/07/11 \\
\hline DOL & 5508.960 & -16151.683 & 442 & L4 & 1996/07/11 \\
\hline DRR3 & 5458.014 & -16215.665 & 457 & L4 & 1996/07/11 \\
\hline DT1 & 5506.427 & -16216.859 & 198 & L4 & $1991 / 06 / 21$ \\
\hline DTN & 5508.744 & -16215.419 & 396 & S13 & 1988/07/16 \\
\hline \multicolumn{6}{|c|}{ Gareloi Volcano subnet (6 stations - 8 components) } \\
\hline GAEA & 5146.980 & -17844.810 & 326 & L4 & 2003/08/30 \\
\hline GAKI & 5133.267 & -17848.725 & 99 & L4 & 2003/09/01 \\
\hline GALA & 5145.704 & -17846.292 & 315 & L4 & 2003/08/30 \\
\hline GANE & 5149.135 & -17846.603 & 325 & L4 & 2003/09/02 \\
\hline GANO & 5149.220 & -17848.230 & 451 & L4 & 2003/09/02 \\
\hline GASW & 5146.731 & -17851.276 & 248 & L22 & 2003/08/30 \\
\hline
\end{tabular}


$\underline{\text { Station Latitude (N) Longitude (E) Elevation (m) }}$ Seismometer $\quad$ Station open date

\begin{tabular}{|c|c|c|c|c|c|}
\hline \multicolumn{6}{|c|}{ Great Sitkin Volcano subnet (6 stations - 8 components) } \\
\hline GSCK & 5200.712 & -17609.718 & 384 & L4 & 1999/09/15 \\
\hline GSIG & 5159.181 & -17555.502 & 407 & L4 & 1999/09/03 \\
\hline GSMY & 5202.594 & -17603.376 & 418 & L4 & 1999/09/03 \\
\hline GSSP & 5205.566 & -17610.541 & 295 & L4 & 1999/09/15 \\
\hline $\mathrm{GSTD}^{3}$ & 5203.356 & -17608.685 & 873 & L22 & 1999/09/03 \\
\hline GSTR & 5205.655 & -17603.546 & 536 & L4 & 1999/09/03 \\
\hline
\end{tabular}

Iliamna Volcano subnet (6 stations - 8 components)

$\begin{array}{lllrll}\text { ILI } & 6004.877 & -15257.502 & 771 & \text { L4 } & 1987 / 09 / 15 \\ \text { ILS } & 5957.454 & -15304.083 & 1,125 & \text { S13 } & 1996 / 08 / 28 \\ \text { ILW } & 6003.585 & -15308.222 & 1,646 & \text { S13 } & 1994 / 09 / 09 \\ \text { INE } & 6003.65 & -15303.75 & 1,585 & \text { S13 } & 1990 / 08 / 29 \\ \text { IVE }^{3} & 6001.014 & -15300.981 & 1,173 & \text { S13,L22 } & 1996 / 09 / 19 \\ \text { IVS } & 6000.55 & -15304.85 & 2,332 & \text { S13 } & 1990 / 08 / 29\end{array}$

Kanaga Volcano subnet (6 stations - 6 components)

$\begin{array}{llllll}\text { KICM } & 5155.136 & -17711.718 & 183 & \text { L4 } & 1999 / 09 / 15 \\ \text { KIKV } & 5152.730 & -17710.223 & 411 & \text { L4 } & 1999 / 09 / 15 \\ \text { KIMD } & 5145.697 & -17714.093 & 183 & \text { L4 } & 1999 / 09 / 15 \\ \text { KINC } & 5155.884 & -17707.657 & 198 & \text { L4 } & 1999 / 09 / 15 \\ \text { KIRH } & 5153.976 & -17705.611 & 309 & \text { L4 } & 1999 / 09 / 03 \\ \text { KIWB } & 5151.183 & -17709.049 & 244 & \text { L4 } & 1999 / 09 / 03\end{array}$

Katmai Volcanic Cluster subnet (20 stations - 30 components)

\begin{tabular}{|c|c|c|c|c|c|}
\hline $\mathrm{ACH}^{3}$ & 5812.64 & -15519.56 & 960 & L22 & $1996 / 07 / 25$ \\
\hline ANCK & 5811.93 & -15529.64 & 869 & L4 & $1996 / 07 / 25$ \\
\hline CAHL & 5803.15 & -15518.09 & 807 & L4 & $1996 / 07 / 25$ \\
\hline CNTC & 5815.87 & -15553.02 & 1,158 & L4 & $1996 / 07 / 25$ \\
\hline KABR & 5807.87 & -15458.15 & 884 & L4 & 1998/08/12 \\
\hline $\mathrm{KABU}^{3}$ & 5816.225 & -15516.934 & 1,065 & CMT-6TD & $2004 / 08 / 01$ \\
\hline КАHC & 5838.94 & -15500.36 & 1,250 & L4 & 1998/10/12 \\
\hline KAHG & 5829.64 & -15432.78 & 923 & L4 & 1998/10/12 \\
\hline KAIC & 5829.10 & -15502.75 & 734 & L4 & 1998/10/12 \\
\hline $\mathrm{KAKN}^{3}$ & 5817.819 & -15503.668 & 1,049 & CMG-6TD & $2004 / 08 / 01$ \\
\hline $\mathrm{KAPH}^{3}$ & 5835.81 & -15420.81 & 907 & L22 & 1998/10/12 \\
\hline KARR & 5829.87 & -15442.20 & 610 & L4 & 1998/10/12 \\
\hline KAWH & 5823.02 & -15447.95 & 777 & L4 & 1998/10/12 \\
\hline KBM & 5816.50 & -15512.10 & 732 & L4 & $1991 / 07 / 22$ \\
\hline KCE & 5814.60 & -15511.00 & 777 & L4 & $1991 / 07 / 22$ \\
\hline $\mathrm{KCG}^{3}$ & 5818.457 & -15506.684 & 762 & L22 & $1988 / 08 / 01$ \\
\hline KEL & 5826.401 & -15544.442 & 975 & L4 & 1988/08/01 \\
\hline KJL & 5803.24 & -15534.39 & 792 & L4 & $1996 / 07 / 25$ \\
\hline KVT & 5822.90 & -15517.70 & 457 & L4 & 1988/08/01 \\
\hline MGLS & 5808.06 & -15509.65 & 472 & L4 & $1996 / 07 / 25$ \\
\hline \multicolumn{6}{|c|}{ Korovin Volcano subnet (7 stations - 9 components) } \\
\hline KOFP & 5357.08 & -16653.51 & 662 & L4 & 2004/07/02 \\
\hline KOKL & 5347.68 & -16652.35 & 758 & L4 & 2004/07/05 \\
\hline $\mathrm{KOKV}^{3}$ & 5353.03 & -16641.00 & 776 & L22 & 2004/07/05 \\
\hline KONE & 5348.629 & -16644.736 & 253 & L4 & 2004/07/10 \\
\hline KONW & 5348.978 & -16656.187 & 334 & L4 & 2004/07/04 \\
\hline KOSE & 5354.88 & -16646.96 & 625 & L4 & 2004/07/07 \\
\hline KOWE & 5358.16 & -16640.71 & 527 & L4 & 2004/07/06 \\
\hline
\end{tabular}




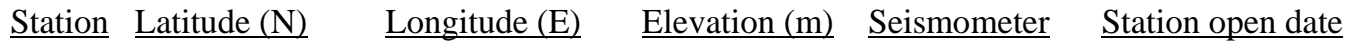

Little Sitkin subnet (4 stations - 6 components)

$\begin{array}{llllll}\text { LSNW } & 5158.232 & 17831.011 & 290 & \text { L4 } & 2005 / 09 / 30 \\ \text { LSPA }^{3} & 5157.413 & 17834.405 & 335 & \text { L4-3D } & 2005 / 09 / 30 \\ \text { LSSSA } & 5156.973 & 17830.793 & 549 & \text { L4 } & 2005 / 09 / 28 \\ \text { LSSE } & 5155.993 & 17834.139 & 335 & \text { L4 } & 2005 / 09 / 27\end{array}$

\begin{tabular}{|c|c|c|c|c|c|}
\hline \multicolumn{6}{|c|}{ Makushin Volcano subnet (7 stations - 9 components) } \\
\hline MCIR & 5357.086 & -16653.529 & 800 & L4 & $1996 / 07 / 25$ \\
\hline MGOD & 5347.683 & -16652.561 & 650 & L4 & 1996/07/25 \\
\hline MNAT & 5353.028 & -16641.016 & 397 & L4 & $1996 / 07 / 25$ \\
\hline MREP & 5348.629 & -16644.736 & 785 & L4 & 2002/01/01 \\
\hline MSOM & 5348.978 & -16656.187 & 146 & L4 & 1996/07/25 \\
\hline $\mathrm{MSW}^{3}$ & 5354.929 & -16647.186 & 418 & L22 & 1996/07/25 \\
\hline MTBL & 5358.136 & -16640.760 & 810 & L4 & $1996 / 07 / 25$ \\
\hline \multicolumn{6}{|c|}{ Okmok Volcano subnet (13 stations - 21 components) } \\
\hline OKAS & 5324.319 & -16821.686 & 270 & L4 & 2003/01/09 \\
\hline $\mathrm{OKCD}^{3}$ & 5325.818 & -16806.737 & 459 & CMG-6TD & 2003/01/09 \\
\hline $\mathrm{OKCE}^{3}$ & 5325.622 & -16809.858 & 515 & CMG-6TD & 2003/01/09 \\
\hline OKCF & 5323.749 & -16808.175 & 685 & $\mathrm{~L} 4$ & 2003/01/09 \\
\hline OKER & 5327.278 & -16802.960 & 956 & L4 & 2003/01/09 \\
\hline $\mathrm{OKFG}^{3}$ & 5324.702 & -16754.568 & 201 & CMG-6TD & $2003 / 01 / 09$ \\
\hline OKID & 5328.645 & -16748.972 & 437 & $\mathrm{~L} 4$ & 2003/01/09 \\
\hline OKRE & 5331.215 & -168 09.846 & 422 & L4 & 2003/01/09 \\
\hline $\mathrm{OKSO}^{3}$ & 5321.447 & -16809.591 & 460 & CMG-6TD & $2004 / 09 / 01$ \\
\hline OKSP & 5315.156 & -168 17.431 & 608 & $\mathrm{~L} 4$ & 2003/01/09 \\
\hline OKTU & 5323.035 & -16802.466 & 646 & L4 & 2003/01/09 \\
\hline OKWE & 5328.328 & -168 14.388 & 445 & L4 & 2003/01/09 \\
\hline OKWR & 5326.084 & -168 12.333 & 1,017 & L4 & 2003/01/09 \\
\hline
\end{tabular}

Pavlof Volcano subnet (7 stations - 9 components)

\begin{tabular}{lrrrll} 
BLHA & 5542.227 & -16203.907 & 411 & L4 & $1996 / 07 / 11$ \\
HAG & 5519.068 & -16154.150 & 503 & L4 & $1996 / 07 / 11$ \\
PN7A & 5526.020 & -16159.713 & 838 & L4 & $1996 / 07 / 11$ \\
PS1A & 5525.321 & -16144.425 & 293 & L4 & $1996 / 07 / 11$ \\
PS4A & 5520.811 & -16151.233 & 322 & L4 & $1996 / 07 / 11$ \\
PV6 & 5527.217 & -16155.112 & 747 & L22 & $1996 / 07 / 11$ \\
PVV & 5522.438 & -16147.396 & 161 & L4 & $1996 / 07 / 11$ \\
\multicolumn{7}{r}{} & & & \\
Mount Peulik subnet (7 stations - 9 components) & & \\
PLBL & 5741.990 & -15649.131 & 461 & L4 & $2004 / 08 / 01$ \\
PLK1 & 5748.114 & -15636.433 & 78 & L4 & $2004 / 08 / 01$ \\
PLK2 & 5745.852 & -15619.458 & 401 & L4 & $2004 / 08 / 01$ \\
PLK3 & 5741.320 & -15616.044 & 494 & L22 & $2004 / 08 / 01$ \\
PLK4 & 5737.928 & -15621.464 & 1,031 & L4 & $2004 / 08 / 01$ \\
PLK5 & 5759.864 & -15652.662 & 49 & L4 & $2004 / 08 / 01$ \\
PLWL & 5802.696 & -15620.479 & 585 & L4 & $2004 / 08 / 01$
\end{tabular}


$\underline{\text { Station }}$ Latitude (N) Longitude (E) Elevation (m) Seismometer $\underline{\text { Station open date }}$

\begin{tabular}{lllcll}
\multicolumn{6}{l}{ Redoubt Volcano subnet (7 stations - 12 components) } \\
DFR & 6035.514 & -15241.160 & 1,090 & L4 & $1988 / 08 / 15$ \\
NCT & 6033.789 & -15255.568 & 1,079 & L4 & $1988 / 08 / 14$ \\
RDN & 6031.377 & -15244.273 & 1,400 & L4 & $1988 / 08 / 13$ \\
RDT & 6034.394 & -15224.315 & 930 & L4 & $1971 / 08 / 09$ \\
RED $^{3}$ & 6025.192 & -15246.308 & 1,064 & L4 & $1990 / 08 / 30$ \\
REF $^{3}$ & 6029.35 & -15242.10 & 1,801 & L22 & $1992 / 07 / 27$ \\
RSO & 6027.73 & -15245.23 & 1,921 & L4 & $1990 / 03 / 01$
\end{tabular}

Semisopochnoi Island subnet (6 stations - 8 components)

$\begin{array}{llllll}\text { CEAP } & 5200.146 & 17947.018 & 244 & \text { L4 } & \text { 2005/09/17 } \\ \text { CEPE } & 5157.948 & 17951.683 & 335 & \text { L4 } & 2005 / 09 / 17 \\ \text { CERA } & 5154.419 & 17915.665 & 305 & \text { L4 } & 2005 / 09 / 26 \\ \text { CERB }^{3} & 5155.886 & 17916.859 & 305 & \text { L4-3D } & 2005 / 09 / 18 \\ \text { CESW } & 5154.060 & 17915.419 & 238 & \text { L4 } & 2005 / 09 / 18 \\ \text { CETU } & 5157.965 & 17915.419 & 335 & \text { L4 } & 2005 / 09 / 22\end{array}$

Shishaldin Volcano subnet (6 stations - 8 components)

$\begin{array}{llllll}\text { BRPK } & 5438.730 & -16344.449 & 393 & \text { L4 } & 1997 / 07 / 27 \\ \text { ISNN } & 5449.937 & -16346.706 & 466 & \text { L4 } & 1997 / 07 / 27 \\ \text { ISTK } & 5443.929 & -16342.376 & 704 & \text { L4 } & 1997 / 07 / 27 \\ \text { SSLN } & 5448.709 & -16359.756 & 637 & \text { L4 } & 1997 / 07 / 27 \\ \text { SSLS } & 5442.718 & -16359.926 & 817 & \text { L22 } & 1997 / 07 / 27 \\ \text { SSLW } & 5446.307 & -16407.282 & 628 & \text { L4 } & 1997 / 07 / 27\end{array}$

\begin{tabular}{|c|c|c|c|c|c|}
\hline Mount & Spurr subr & stations - 56 & nents; & tations on & stations - 2 \\
\hline BGL & 6116.012 & -15223.340 & 1,127 & L4 & 1989/08/13 \\
\hline BKG & 6104.21 & -15215.76 & 1,009 & L4 & 1991/07/01 \\
\hline CGL & 6118.46 & -15200.40 & 1,082 & L4 & $1981 / 09 / 22$ \\
\hline CKL & 6111.782 & -152 20.268 & 1,281 & L4 & $1989 / 08 / 05$ \\
\hline CKN & 6113.44 & -15210.89 & 735 & L4 & $1991 / 08 / 19$ \\
\hline CKT & 6112.05 & -15212.37 & 975 & L4 & $1992 / 09 / 16$ \\
\hline СР2 & 6115.85 & -15214.51 & 1,981 & L4 & $1992 / 10 / 23$ \\
\hline $\mathrm{CRP}^{3}$ & 6116.02 & -15209.33 & 1,622 & L4 & $1981 / 08 / 26$ \\
\hline NCG & 6124.22 & -15209.40 & 1,244 & L4 & 1989/08/06 \\
\hline $\mathrm{SP} 02^{3}$ & 6110.616 & -152 03.481 & 821 & CMG-6TD & $2005 / 06 / 16^{* *}$ \\
\hline $\mathrm{SP}^{3} 3^{3}$ & 6108.208 & -15202.815 & 882 & CMG-6TD & 2005/06/16** \\
\hline $\mathrm{SP}^{3} 4^{3}$ & 6108.014 & -15215.394 & 946 & CMG-6TD & $2005 / 06 / 16^{* *}$ \\
\hline $\mathrm{SP} 05^{3}$ & 6120.793 & -152 05.296 & 893 & CMG-6TD & $2005 / 06 / 16^{* *}$ \\
\hline SP06 ${ }^{3}$ & 6115.586 & -15211.053 & 1,192 & CMG-6TD & $2005 / 06 / 16^{* *}$ \\
\hline SP07 ${ }^{3}$ & 6120.781 & -15157.842 & 1,113 & CMG-6TD & $2005 / 06 / 16^{* *}$ \\
\hline $\mathrm{SP}^{3}$ & 6119.956 & -15226.700 & 1,545 & CMG-6TD & $2005 / 06 / 16^{* *}$ \\
\hline SP09 $^{3}$ & 6114.137 & -15147.920 & 814 & CMG-6TD & $2005 / 06 / 16^{* *}$ \\
\hline SP $10^{3}$ & 6122.465 & -15230.981 & 1,429 & CMG-6TD & $2005 / 06 / 16^{* *}$ \\
\hline SP11 ${ }^{3}$ & 6110.780 & -152 37.253 & 921 & CMG-6TD & 2005/06/16** \\
\hline $\mathrm{SP} 12^{3}$ & 6123.627 & -152 07.974 & 1,034 & CMG-6TD & $2005 / 06 / 16^{* *}$ \\
\hline $\mathrm{SPBG}^{3}$ & 6115.583 & -152 22.194 & 1,087 & CMG-6TD & 2004/09/09 \\
\hline $\mathrm{SPCG}^{3}$ & 6117.512 & -15201.228 & 1,329 & CMG-6TD & 2004/09/08 \\
\hline $\mathrm{SPCR}^{3}$ & 6112.051 & -15212.409 & 984 & CMG-6TD & $2004 / 09 / 08$ \\
\hline SPNW & 6120.826 & -15236.236 & 1,040 & L4 & $2004 / 08 / 17$ \\
\hline SPU & 6110.90 & -15203.26 & 800 & L4 & $1971 / 08 / 10$ \\
\hline SPWE & 6116.405 & -15233.545 & 1,327 & L4 & $2004 / 08 / 18$ \\
\hline
\end{tabular}




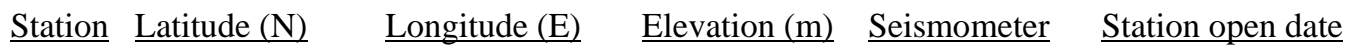

Tanaga Volcano subnet (6 stations - 8 components)

$\begin{array}{llllll}\text { TACS } & 5151.792 & -17808.363 & 918 & \text { L4 } & 2003 / 08 / 28 \\ \text { TAFL } & 5145.396 & -17753.867 & 186 & \text { L4 } & 2003 / 08 / 28 \\ \text { TAFP }^{3} & 5154.003 & -17758.997 & 440 & \text { L22 } & 2003 / 08 / 27 \\ \text { TANO } & 5154.942 & -17807.249 & 269 & \text { L4 } & 2003 / 08 / 24 \\ \text { TAPA } & 5148.932 & -17748.770 & 640 & \text { L4 } & 2003 / 08 / 27 \\ \text { TASE } & 5150.099 & -17802.222 & 682 & \text { L4 } & 2003 / 08 / 24\end{array}$

Mount Veniaminof subnet (9 stations - 9 components)

$\begin{array}{lrrrrr}\text { BPBC } & 5635.383 & -15827.153 & 584 & \text { L4 } & 2002 / 10 / 03 \\ \text { VNFG } & 5617.140 & -15933.066 & 1,068 & \text { L4 } & 2002 / 02 / 06 \\ \text { VNHG } & 5613.267 & -15909.853 & 966 & \text { L4 } & 2002 / 02 / 06 \\ \text { VNKR } & 5601.871 & -15922.068 & 620 & \text { L4 } & 2002 / 02 / 06 \\ \text { VNNF } & 5617.022 & -15918.961 & 1,153 & \text { L4 } & 2002 / 06 / 20 \\ \text { VNSG } & 5607.549 & -15905.121 & 761 & \text { L4 } & 2002 / 02 / 06 \\ \text { VNSS } & 5613.600 & -15927.290 & 1,733 & \text { L4 } & 2002 / 02 / 06 \\ \text { VNSW } & 5604.317 & -15933.508 & 716 & \text { L4 } & 2002 / 06 / 20 \\ \text { VNWF } & 5609.104 & -15933.733 & 1,095 & \text { L4 } & 2002 / 02 / 06\end{array}$

Westdahl Peak subnet (6 stations - 8 components)

$\begin{array}{llllll}\text { WESE } & 5428.389 & -16435.038 & 953 & \text { L4 } & 1998 / 08 / 28 \\ \text { WESN } & 5434.600 & -16434.703 & 549 & \text { L4 } & 1998 / 10 / 17 \\ \text { WESS }^{3} 5428.828 & -16443.333 & 908 & \text { L22 } & 1998 / 08 / 28 \\ \text { WFAR } & 5432.029 & -16446.567 & 640 & \text { L4 } & 1998 / 08 / 28 \\ \text { WPOG } 5435.837 & -16444.606 & 445 & \text { L4 } & 1998 / 10 / 17 \\ \text { WTUG 54 50.847 } & -16423.117 & 636 & \text { L4 } & 1998 / 10 / 17\end{array}$

Mount Wrangell subnet (4 stations - 6 components)

\begin{tabular}{|c|c|c|c|c|}
\hline WACK ${ }^{3} 6159.178$ & -14419.703 & 2,280 & L22 & $2000 / 07 / 31$ \\
\hline WANC 6200.189 & $-144 \quad 4.195$ & 4,190 & L4 & $2000 / 07 / 31$ \\
\hline WASW 6155.692 & -14410.346 & 2,196 & L4 & 2001/08/03 \\
\hline WAZA 6204.506 & -1449.132 & 2,531 & L4 & 2001/08/03 \\
\hline
\end{tabular}

\begin{tabular}{llllll}
\multicolumn{2}{l}{ Regional stations (9 stations - 9 components) } & & & \\
ADAG & 5158.812 & -17636.104 & 286 & L4 & $1999 / 09 / 15$ \\
BGM & 5923.56 & -15513.76 & 625 & L4 & $1978 / 09 / 08$ \\
BGR & 6045.45 & -15225.06 & 985 & L4 & $1991 / 07 / 01$ \\
CDD & 5855.771 & -15338.558 & 622 & S13 & $1981 / 08 / 17$ \\
ETKA & 5151.712 & -17624.351 & 290 & L4 & $1999 / 09 / 15$ \\
MMN & 5911.11 & -15420.20 & 442 & S13 & $1981 / 08 / 22$ \\
OPT & 5939.192 & -15313.796 & 634 & S13 & $1974 / 00 / 00$ \\
PDB & 5947.27 & -15411.55 & 305 & S13 & $1978 / 09 / 09$ \\
STLK & 6129.926 & -15149.963 & 945 & L4 & $1997 / 09 / 01$
\end{tabular}

Station Codes:

${ }^{3}$ Three-component station

* REF also has a low-gain vertical component.

** Temporary stations removed on 2005/09/14

Seismometer Codes:

CMG-40T Guralp CMG-40T 60 second natural period three-component broadband seismometer

CMG-6TD: Guralp CMG-6TD 30 second natural period three-component broadband seismometer

L4 Mark Products L4 one second natural period single-component seismometer

L4-3D: $\quad$ Mark Products L4-3D one second natural period three-component seismometer

L22: $\quad$ Mark Products L22 0.5 second natural period three-component seismometer

S13: Teledyne Geotech S13 one second natural period single-component seismometer 
Appendix C: Figures showing the locations of the permanent AVO regional and volcano-specific seismograph stations in 2005 . In all figures, closed triangles show volcanic centers and open squares show seismograph stations.

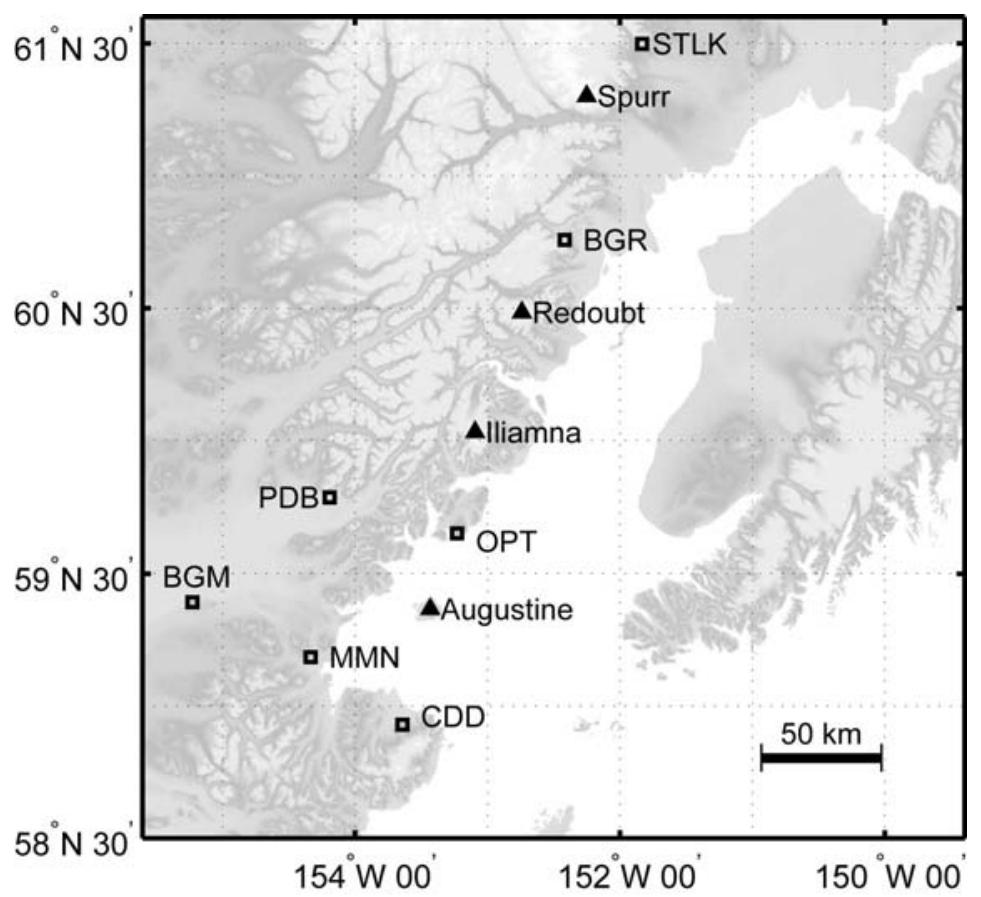

Figure C1. Regional AVO seismograph stations in Cook Inlet. Seismograph stations are shown by open squares. Closed triangles show volcanic centers.

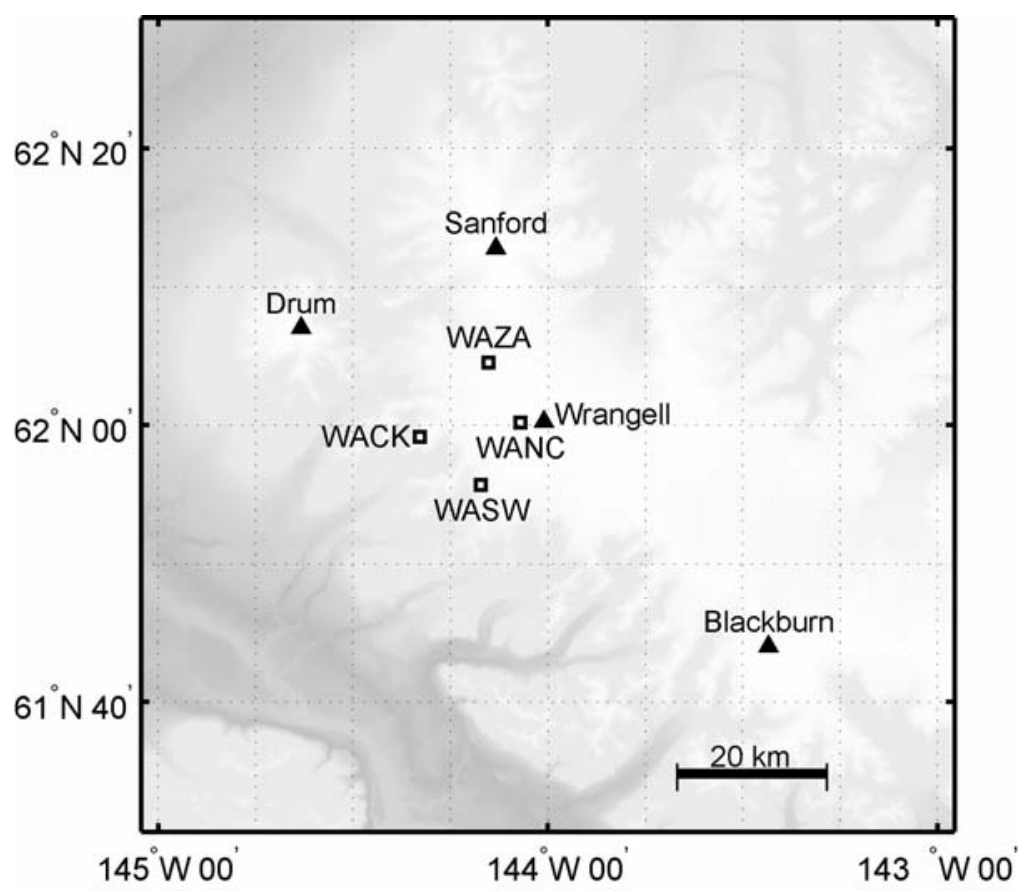

Figure C2. AVO seismograph stations near Mount Wrangell. Seismograph stations are shown by open squares. Closed triangles show volcanic centers. 


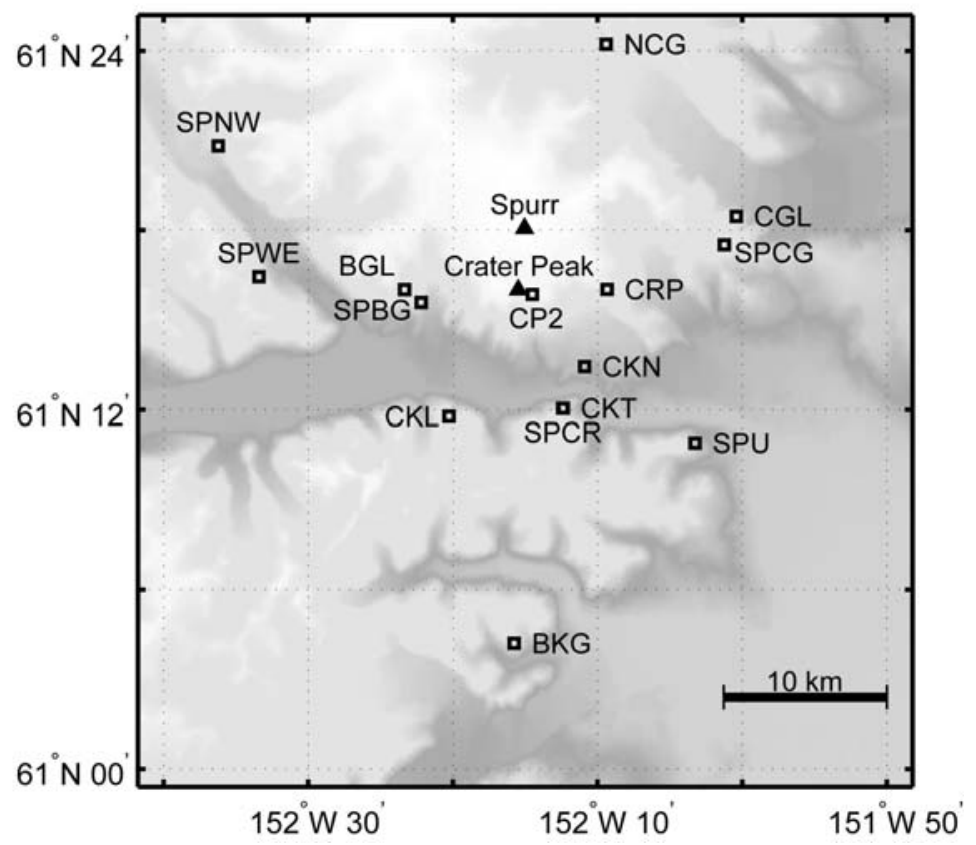

Figure C3. AVO seismograph stations near Mount Spurr. Seismograph stations are shown by open squares. Closed triangles show volcanic centers.

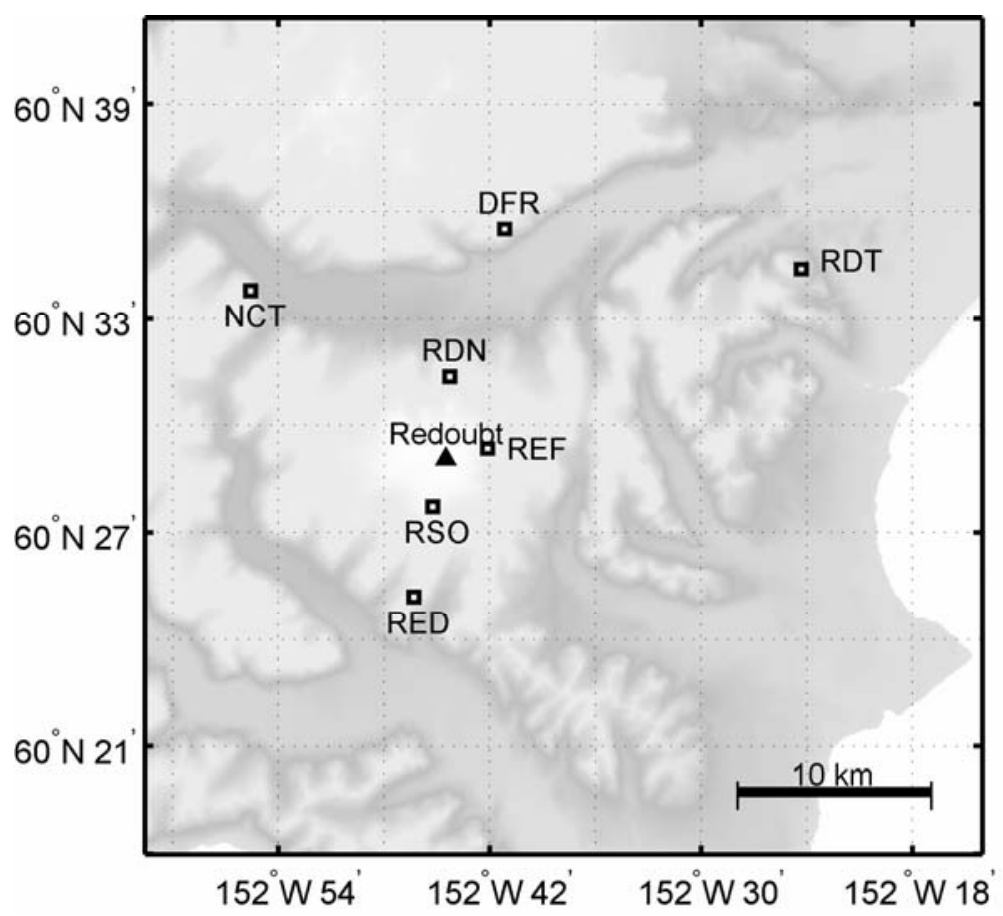

Figure C4. AVO seismograph stations near Redoubt Volcano. Seismograph stations are shown by open squares. Closed triangles show volcanic centers. 


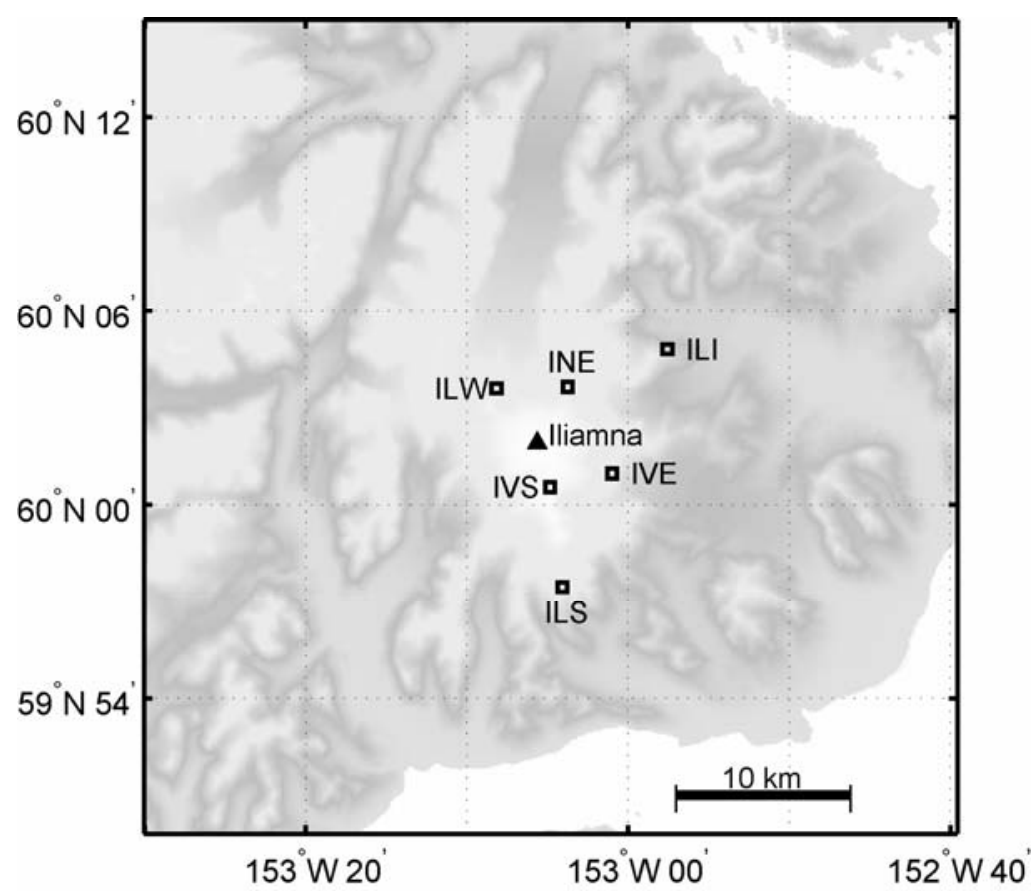

Figure C5. AVO seismograph stations near Iliamna Volcano. Seismograph stations are shown by open squares. Closed triangles show volcanic centers.

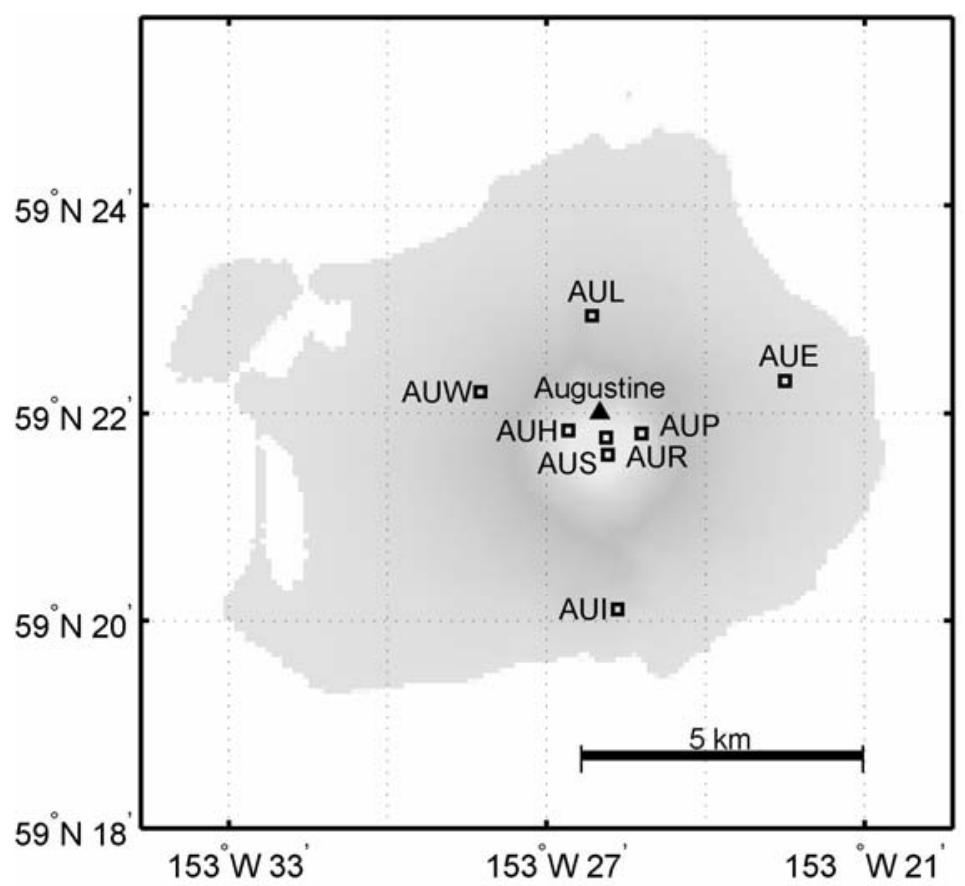

Figure C6. AVO seismograph stations near Augustine Volcano. Seismograph stations are shown by open squares. Closed triangles show volcanic centers. 


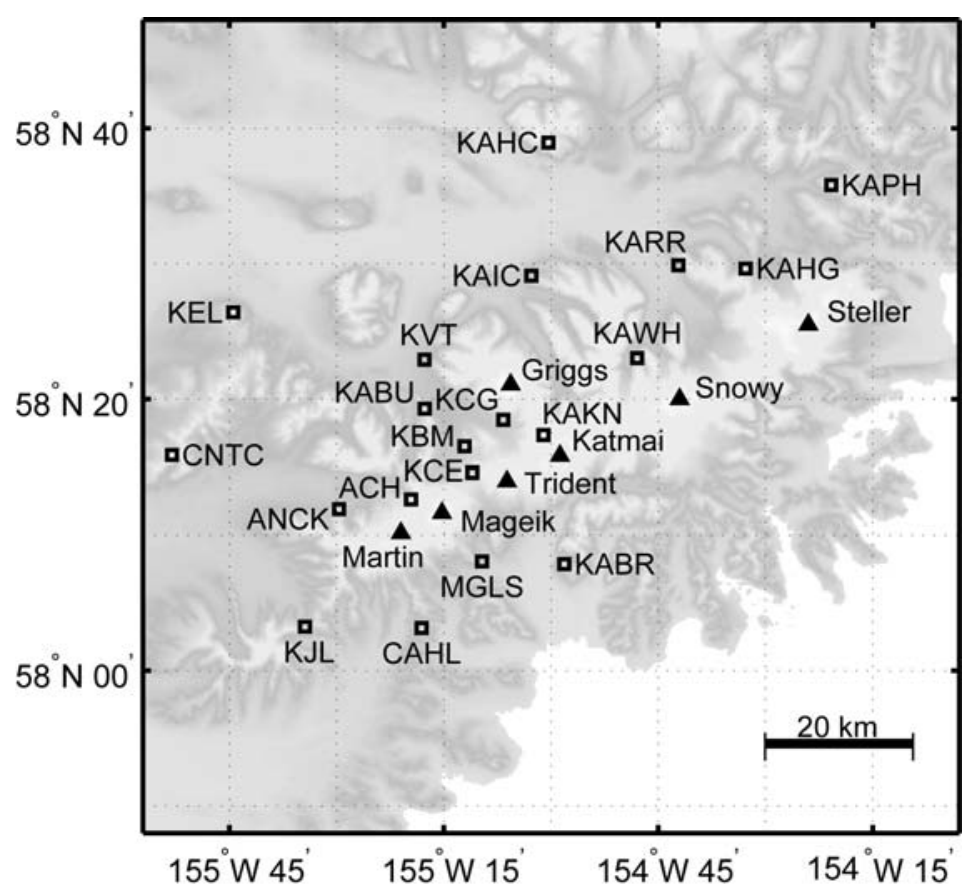

Figure C7. AVO seismograph stations near the Katmai volcanic cluster. Seismograph stations are shown by open squares. Closed triangles show volcanic centers.

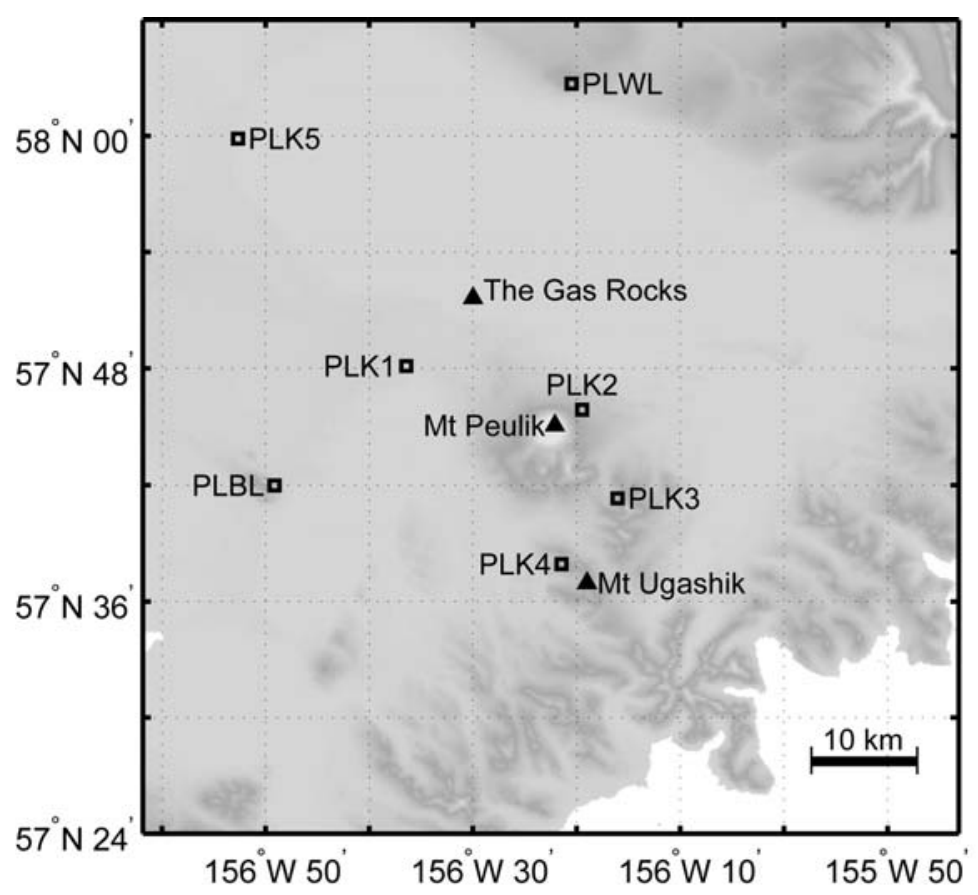

Figure C8. AVO seismograph stations near the Mount Peulik. Seismograph stations are shown by open squares. Closed triangles show volcanic centers. 


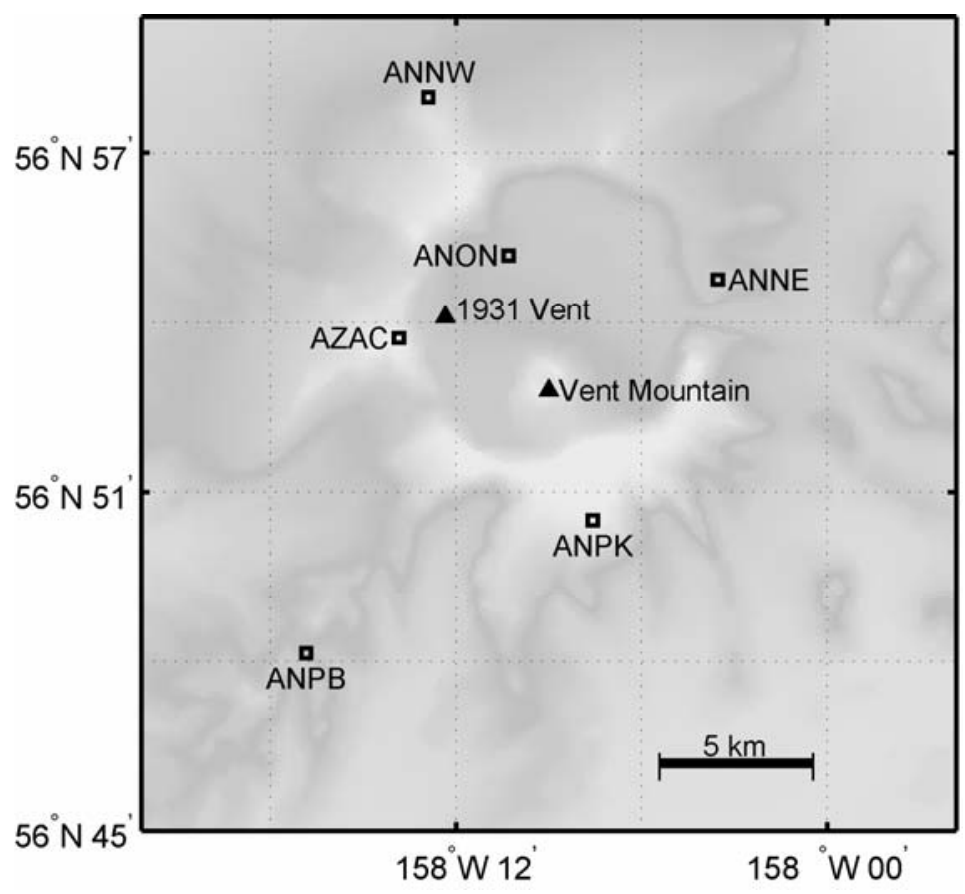

Figure C9. AVO seismograph stations near Aniakchak Crater. Seismograph stations are shown by open squares. Closed triangles show volcanic centers.

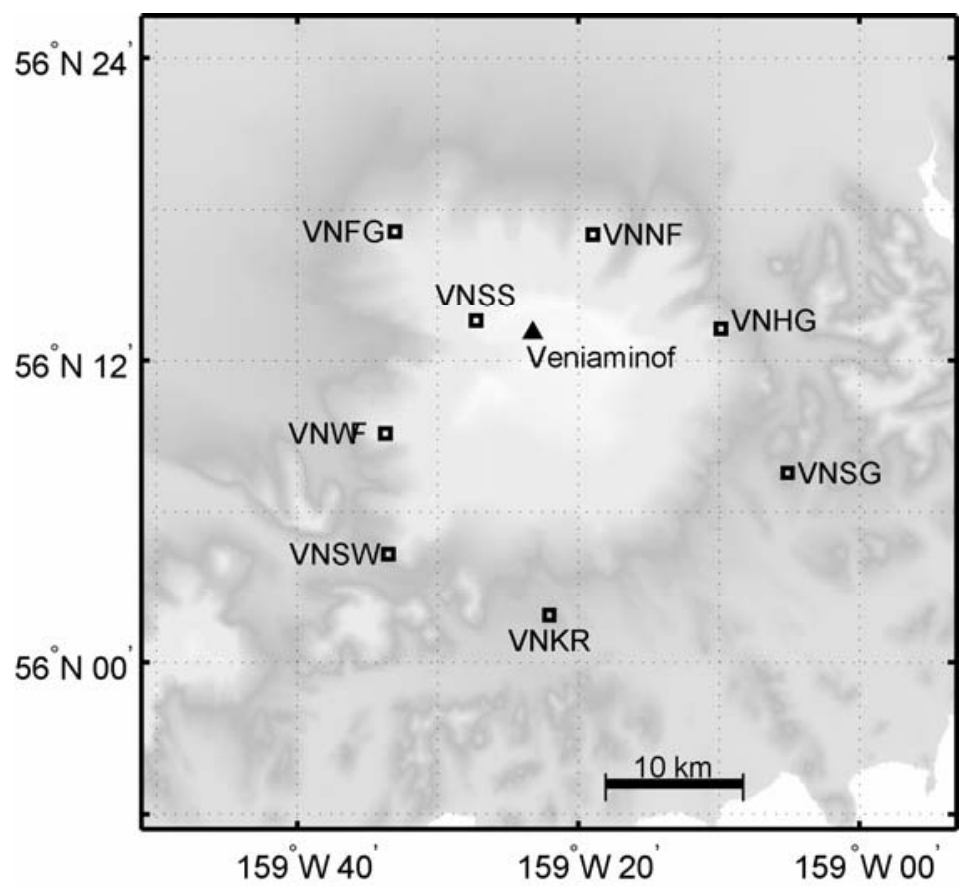

Figure C10. AVO seismograph stations near Mount Veniaminof. Seismograph station $\mathrm{BPBC}$ is not shown and is located $70 \mathrm{~km}$ northeast of Mount Veniaminof. Seismograph stations are shown by open squares. Closed triangles show volcanic centers. 


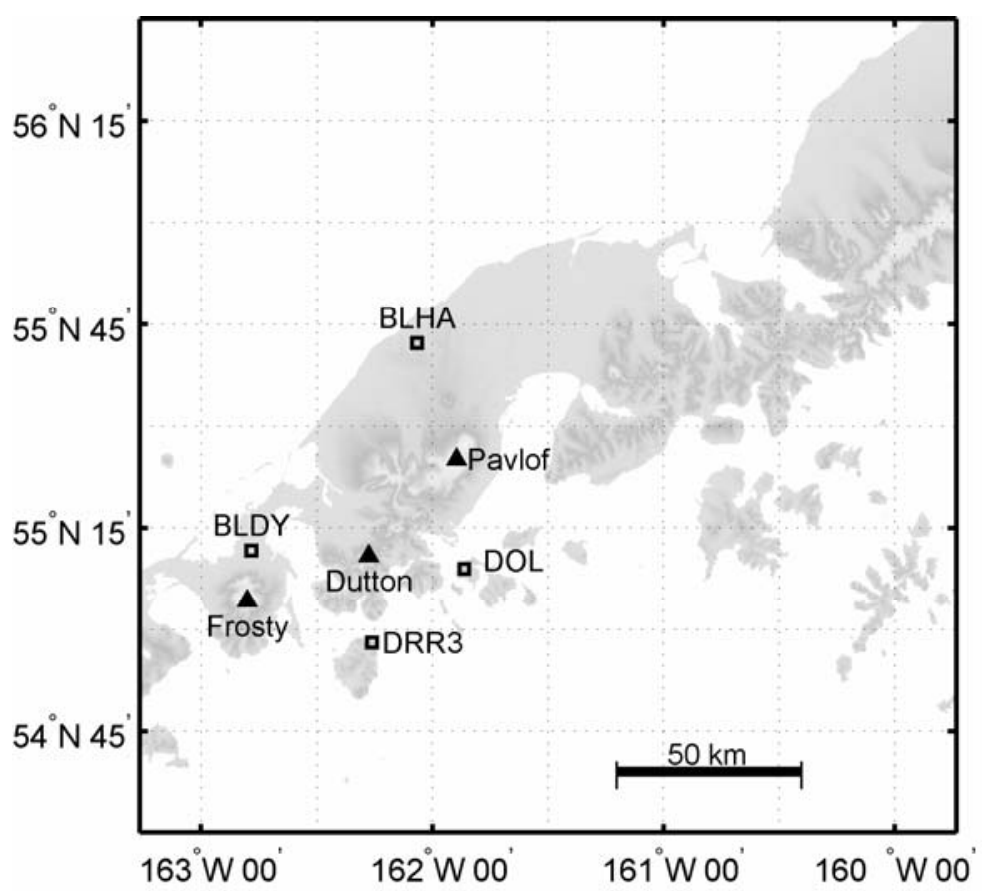

Figure C11. Regional AVO seismograph stations on the western end of the Alaska Peninsula. Seismograph stations are shown by open squares. Closed triangles show volcanic centers.

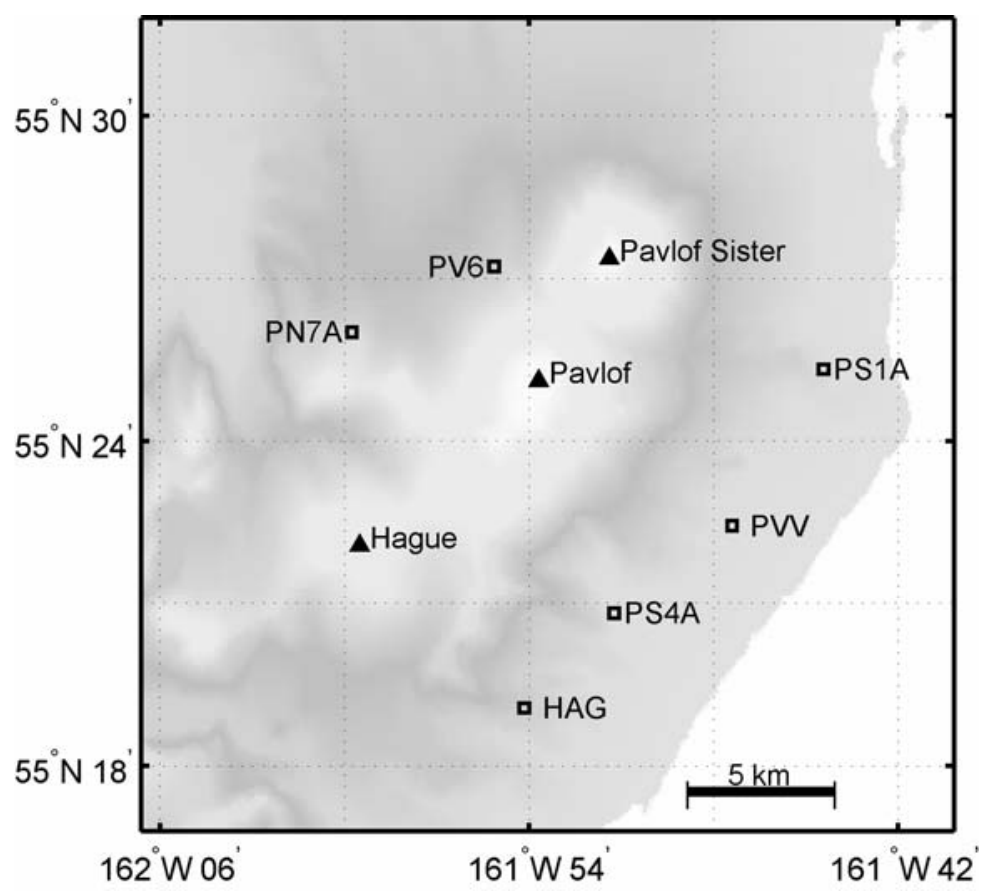

Figure C12. AVO seismograph stations near Pavlof Volcano. Seismograph stations are shown by open squares. Closed triangles show volcanic centers. 


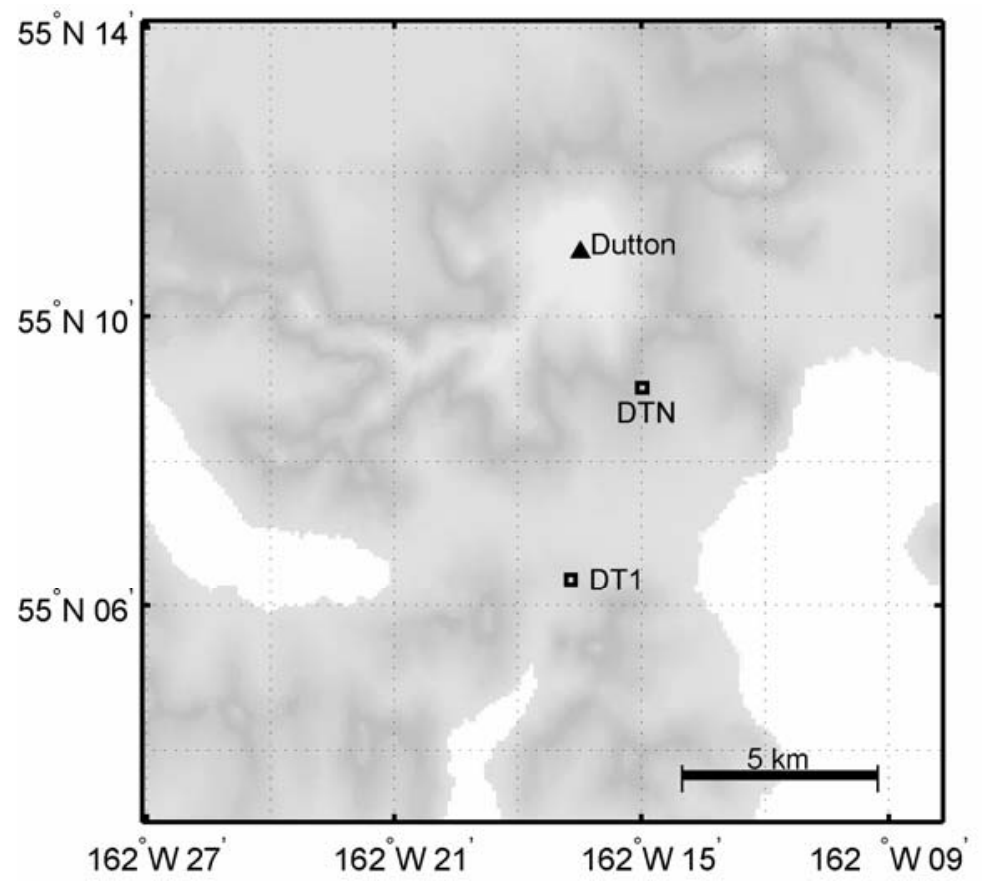

Figure C13. AVO seismograph stations near Mount Dutton. Seismograph stations are shown by open squares. Closed triangles show volcanic centers.

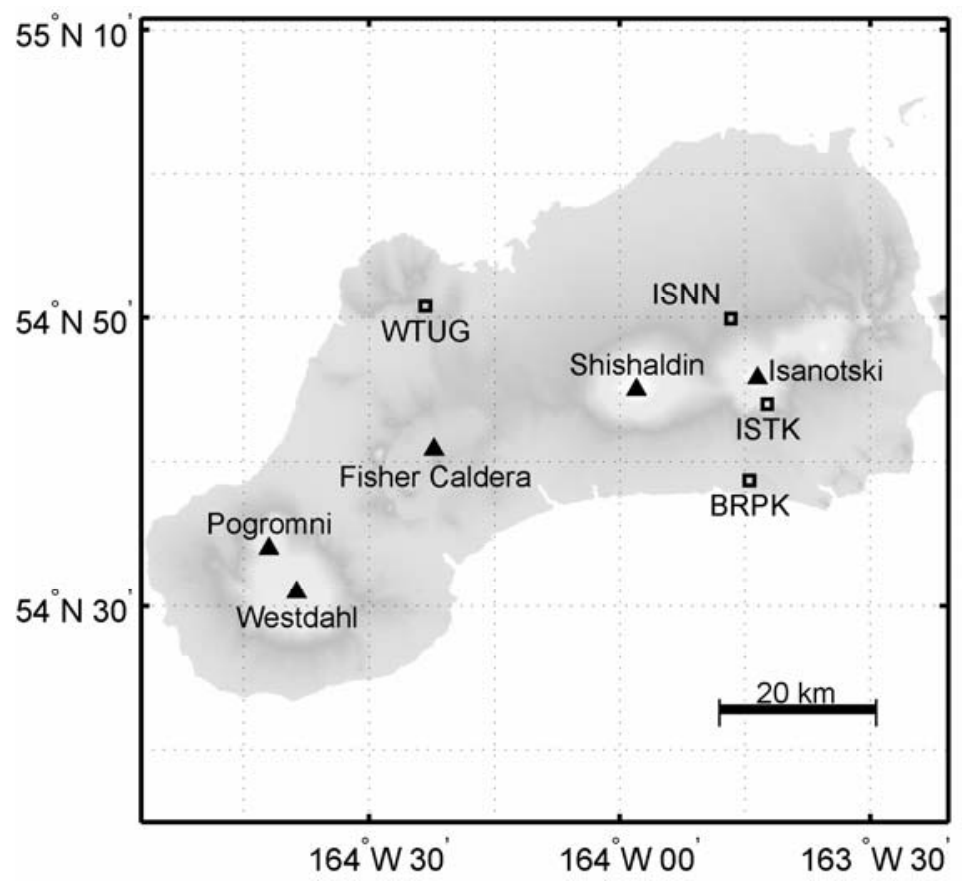

Figure C14. Regional AVO seismograph stations on Unimak Island. Seismograph stations are shown by open squares. Closed triangles show volcanic centers. 


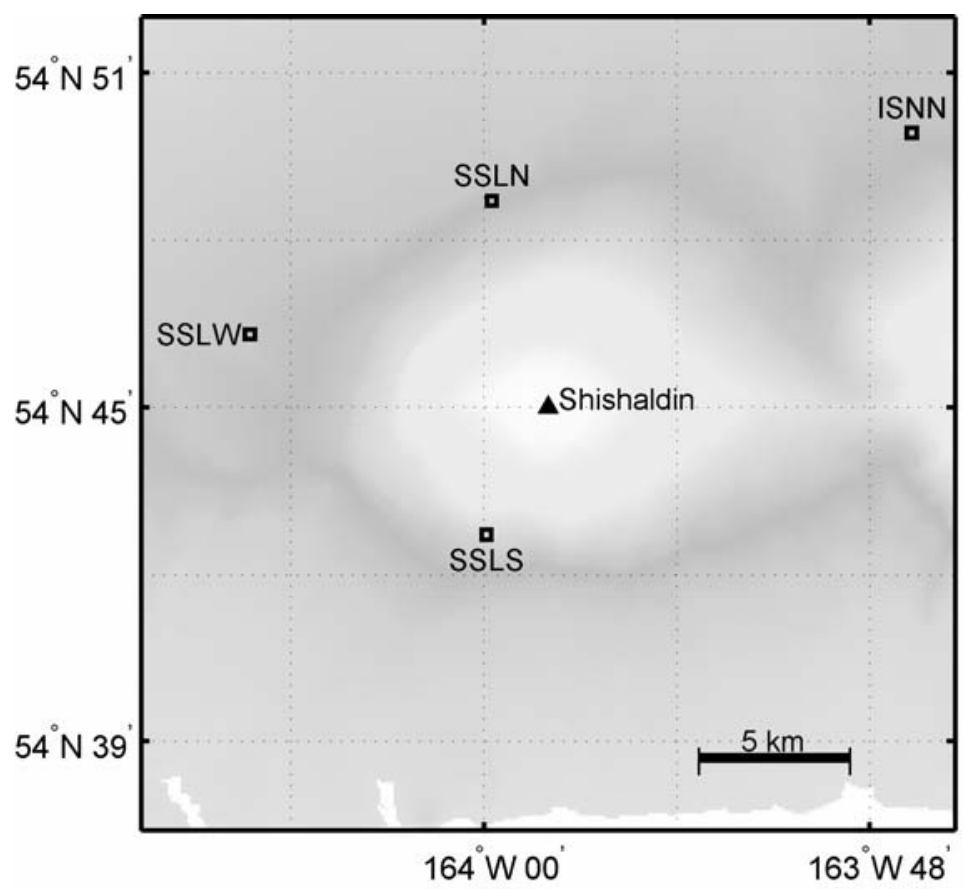

Figure C15. AVO seismograph stations near Shishaldin Volcano. Seismograph stations are shown by open squares. Closed triangles show volcanic centers.

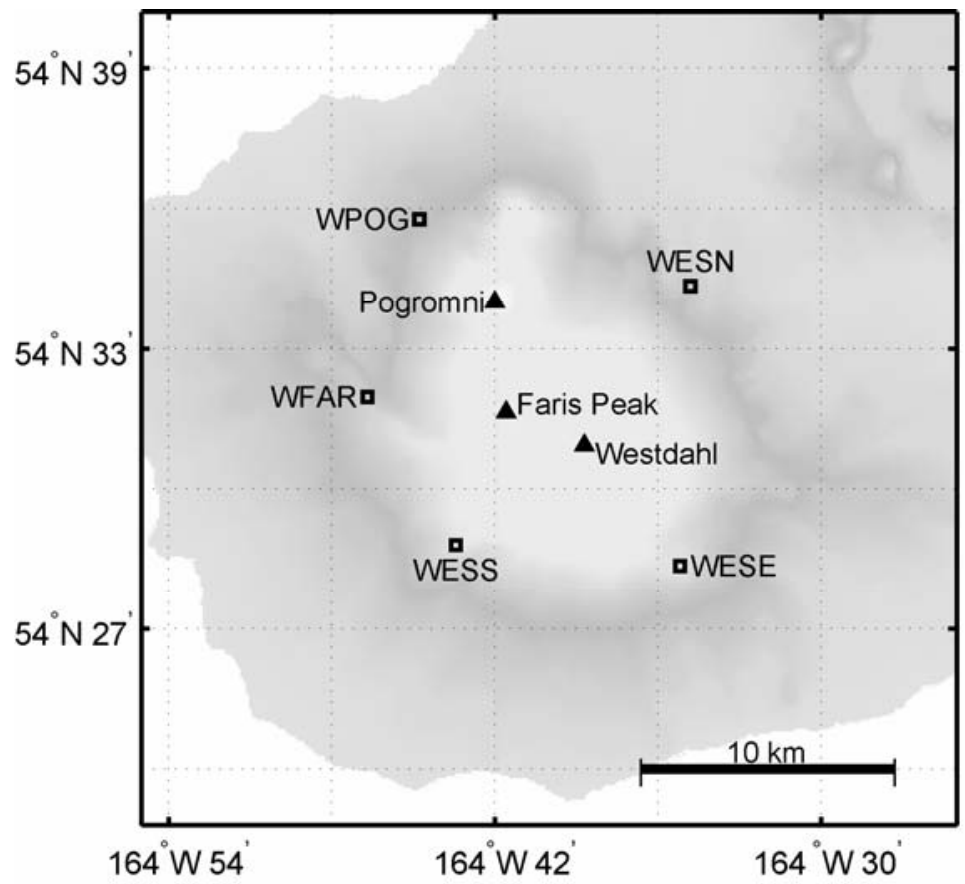

Figure C16. AVO seismograph stations near Westdahl Peak. Seismograph stations are shown by open squares. Closed triangles show volcanic centers. 


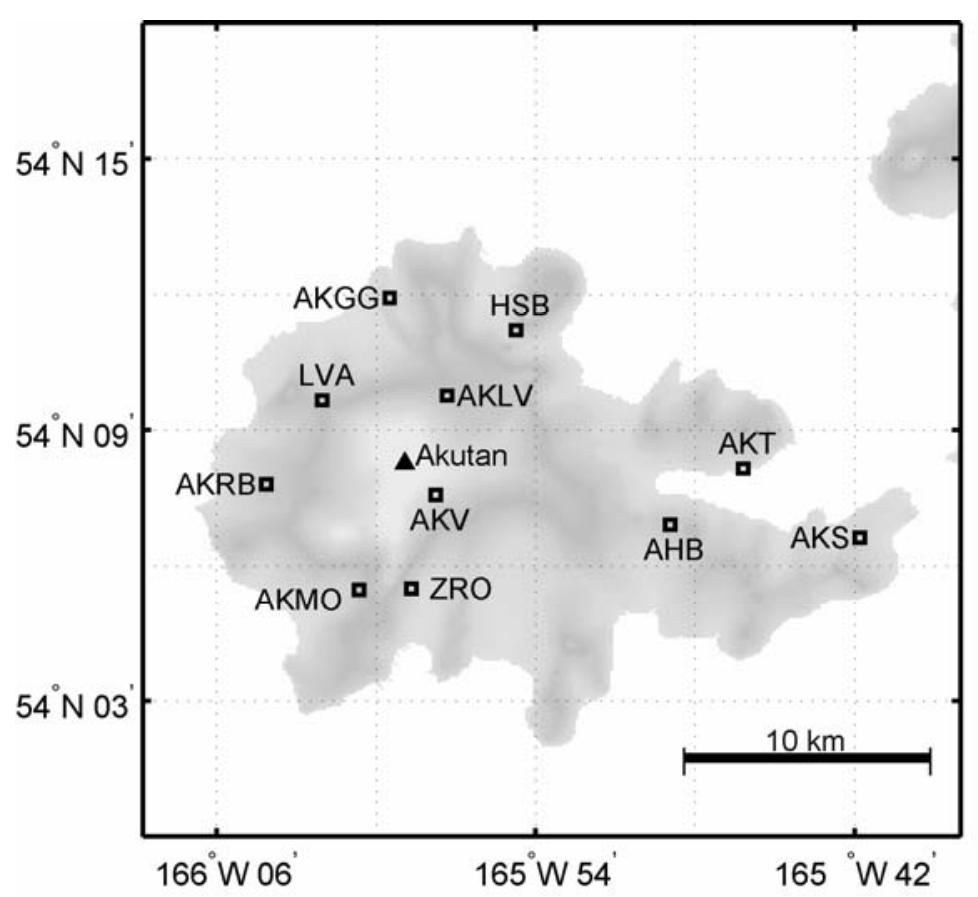

Figure C17. AVO seismograph stations near Akutan Peak. Seismograph stations are shown by open squares. Closed triangles show volcanic centers.

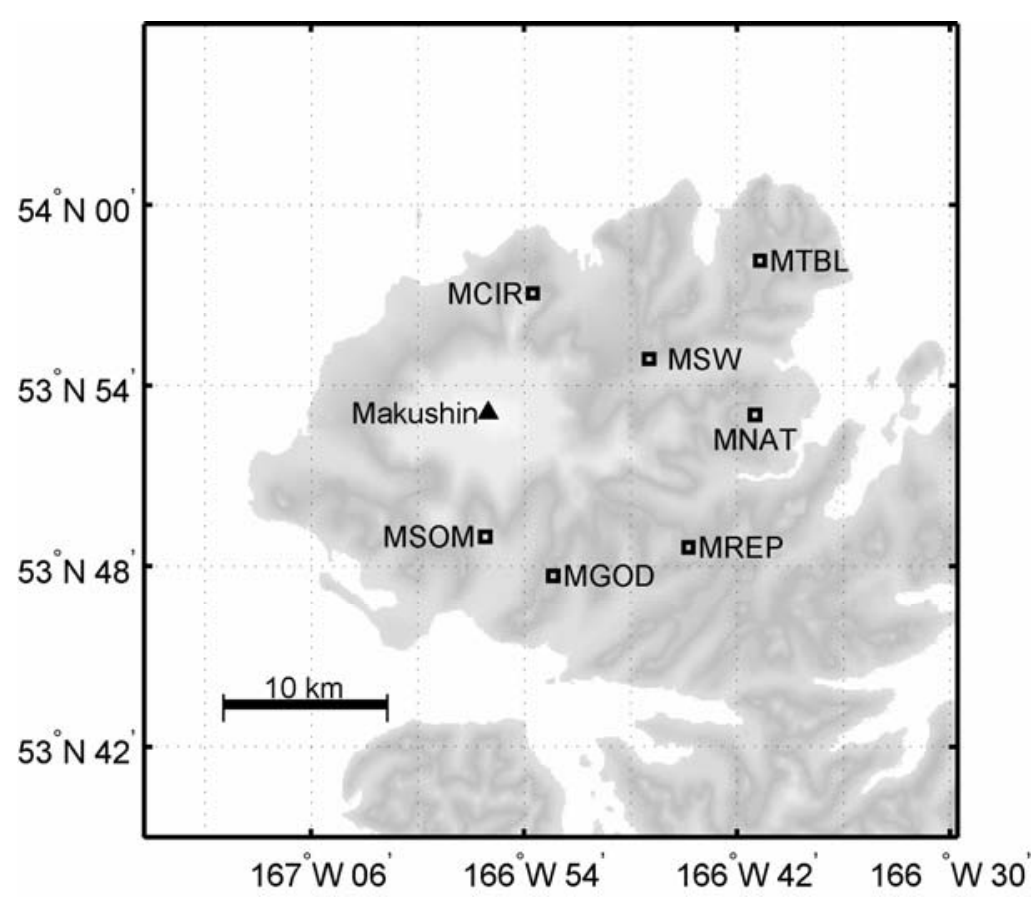

Figure C18. AVO seismograph stations near Makushin Volcano. Seismograph stations are shown by open squares. Closed triangles show volcanic centers. 


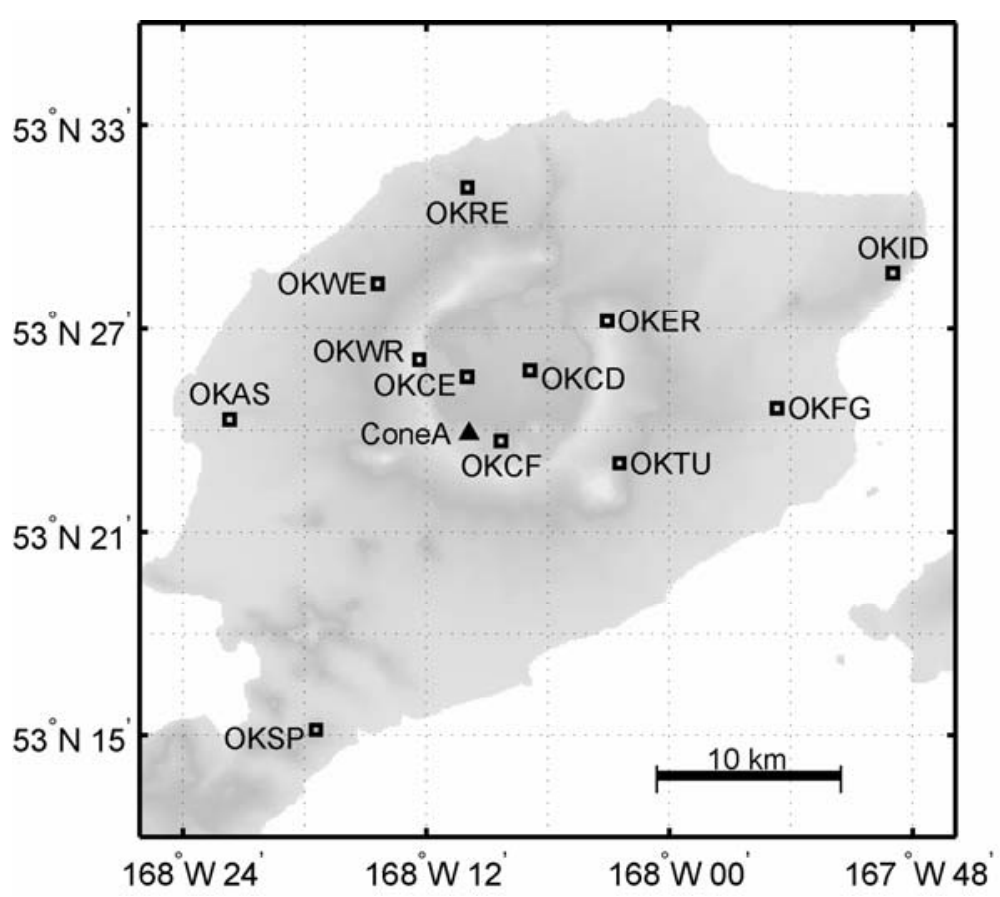

Figure C19. AVO seismograph stations near Okmok Volcano. Seismograph stations are shown by open squares. Closed triangles show volcanic centers.

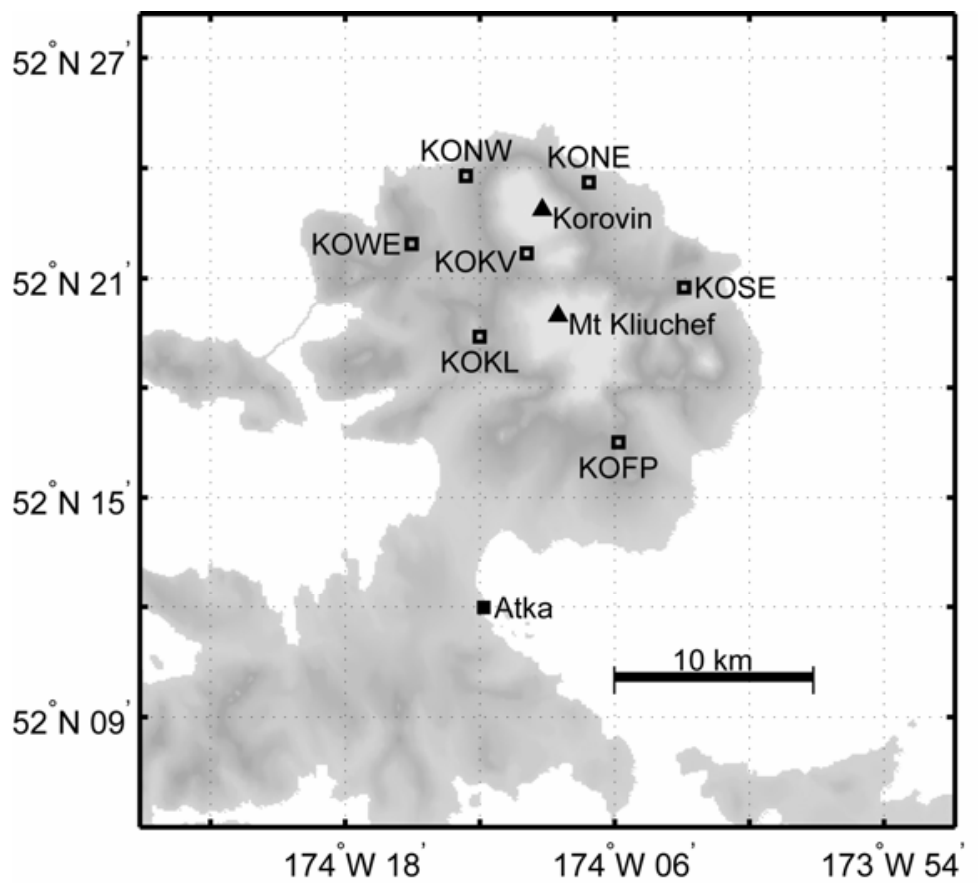

Figure C20. AVO seismograph stations near Korovin Volcano. Seismograph stations are shown by open squares. Closed triangles show volcanic centers. 


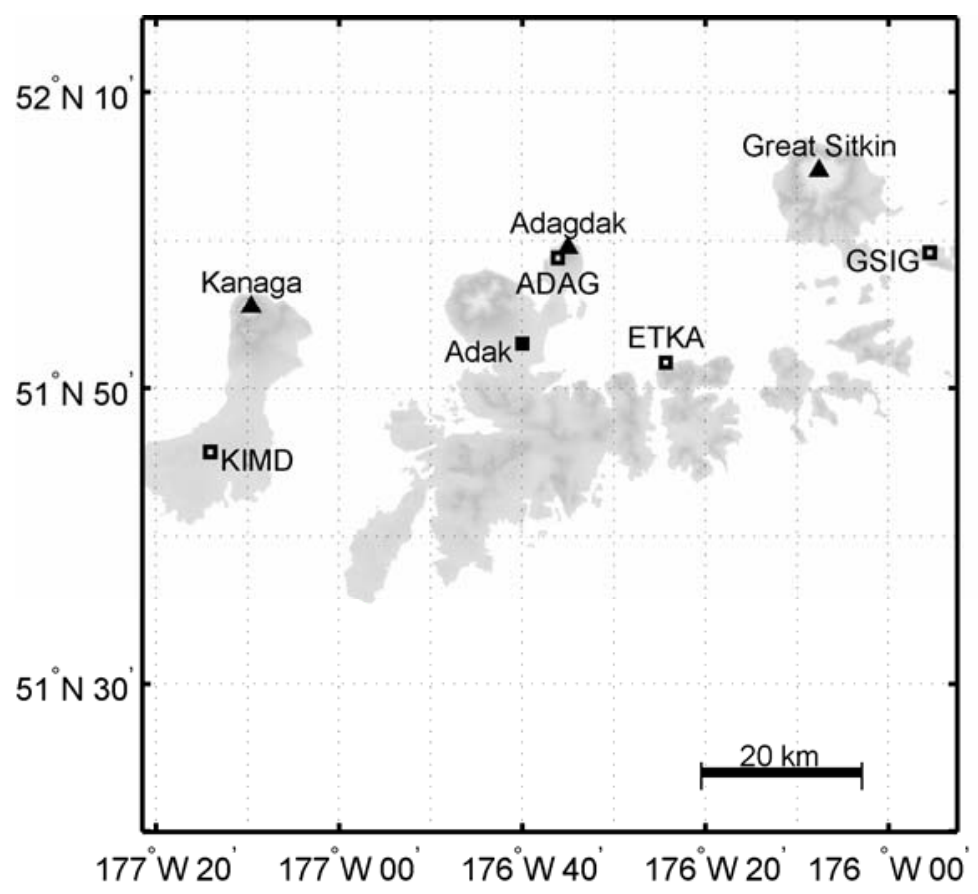

Figure C21. Regional AVO seismograph stations around Adak Island. Seismograph stations are shown by open squares. Closed triangles show volcanic centers.

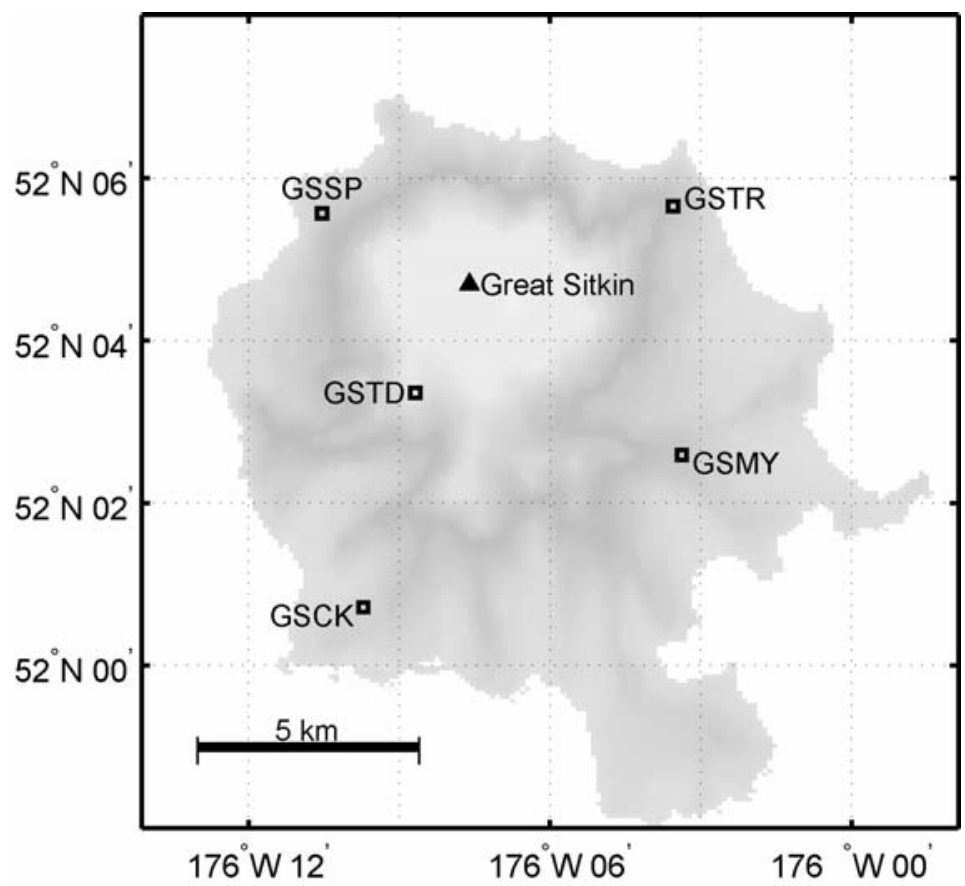

Figure C22. AVO seismograph stations near Great Sitkin Volcano. Seismograph stations are shown by open squares. Closed triangles show volcanic centers. 


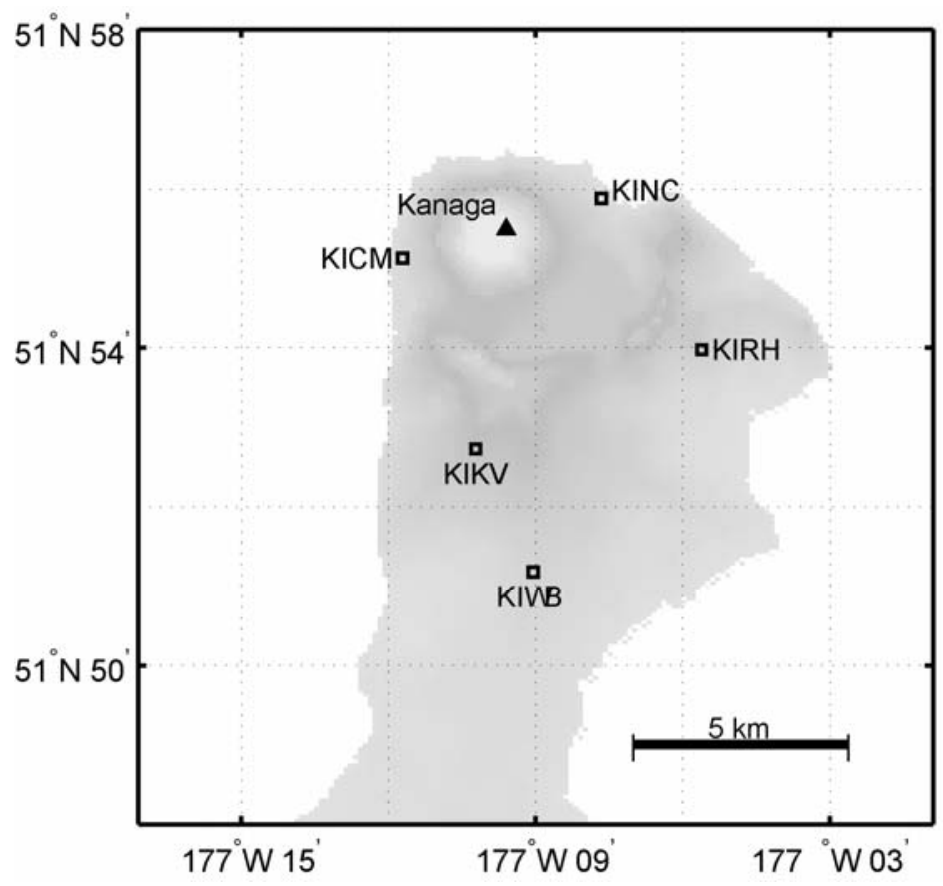

Figure C23. AVO seismograph stations near Kanaga Volcano. Seismograph stations are shown by open squares. Closed triangles show volcanic centers.

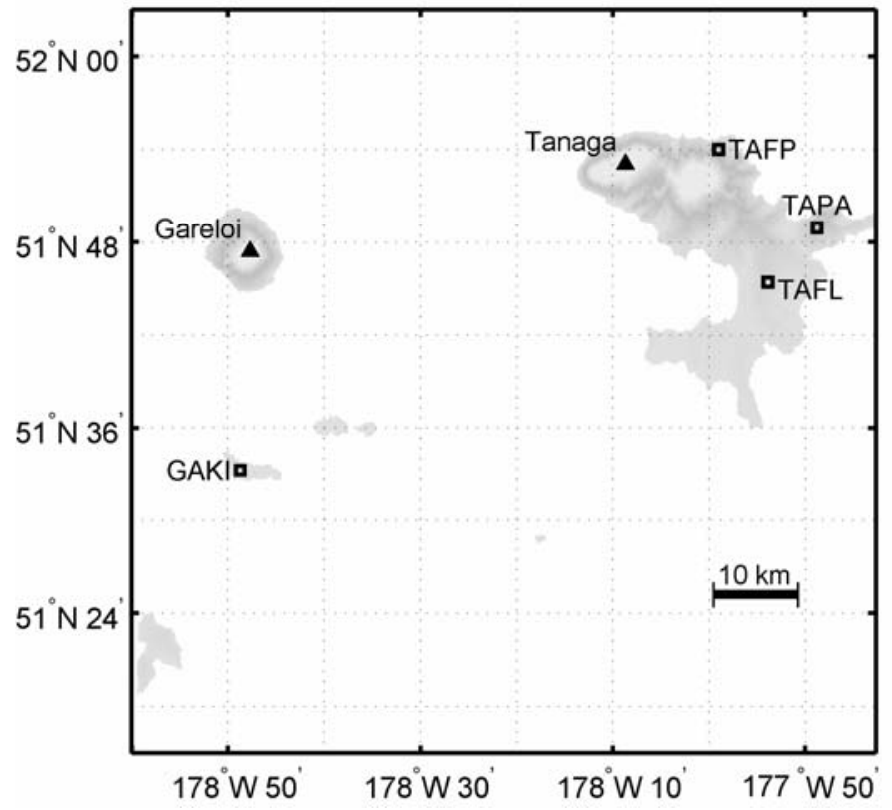

Figure C24. Regional AVO seismograph stations around Tanaga Volcano and Mount Gareloi. Seismograph stations are shown by open squares. Closed triangles show volcanic centers. 


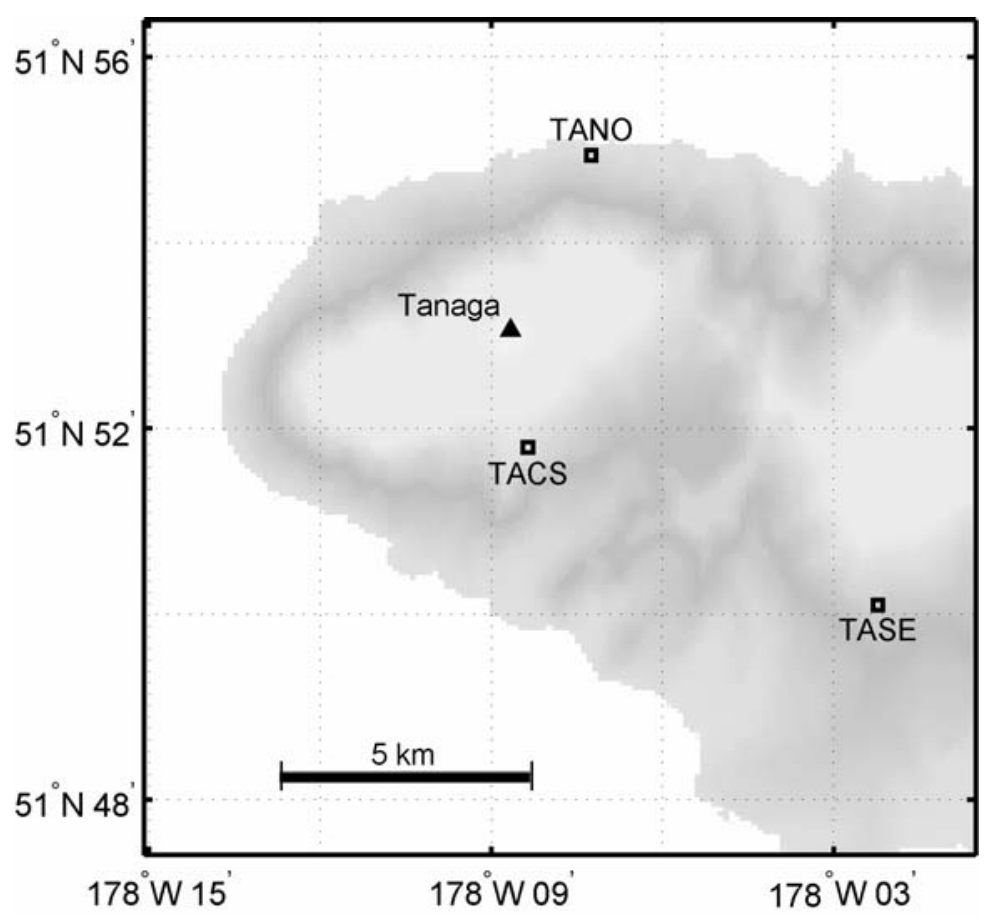

Figure C25. AVO seismograph stations near Tanaga Volcano. Seismograph stations are shown by open squares. Closed triangles show volcanic centers.

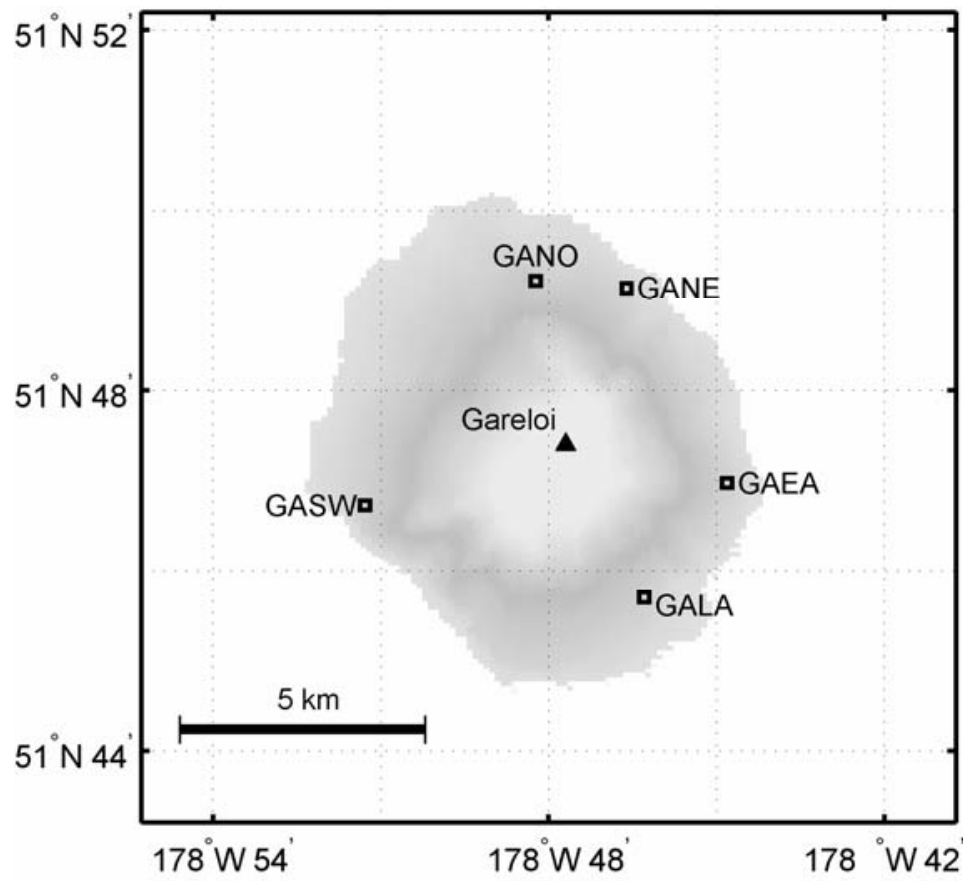

Figure C26. AVO seismograph stations near Mount Gareloi. Seismograph stations are shown by open squares. Closed triangles show volcanic centers. 


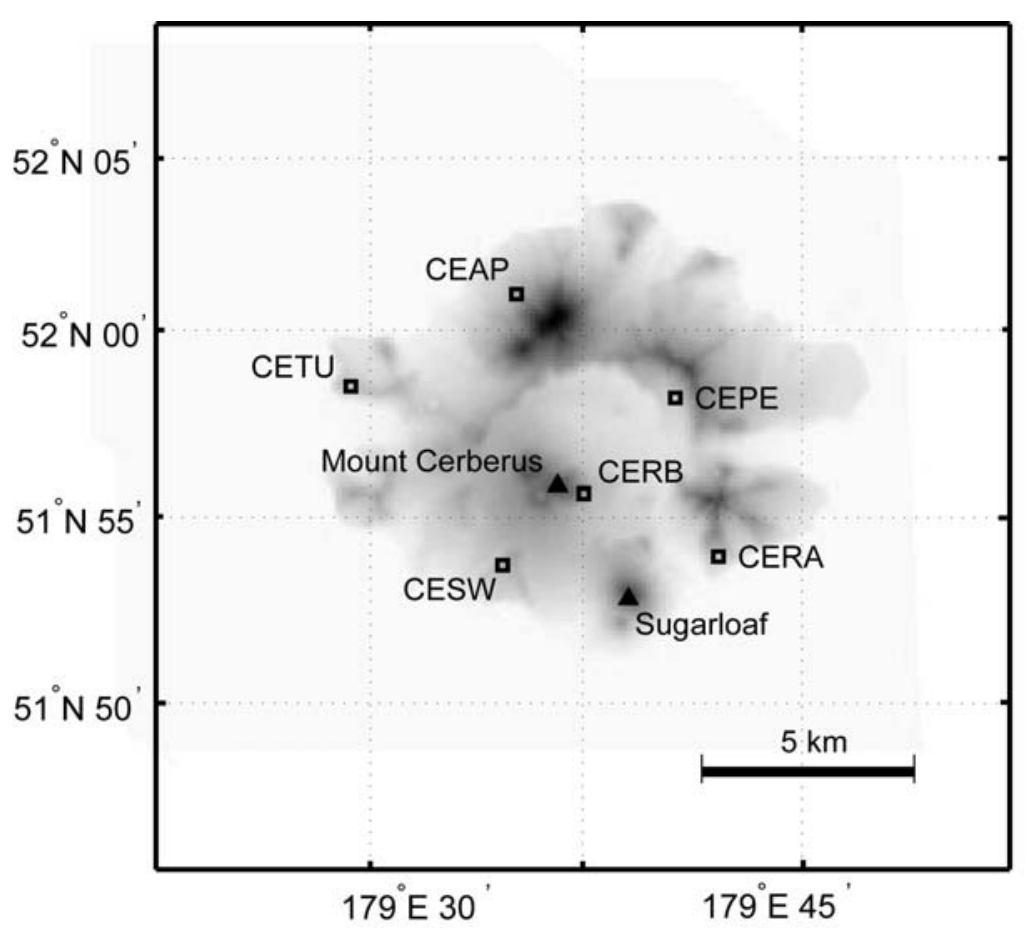

Figure C27. AVO seismograph stations on Semisopochnoi Island. Seismograph stations are shown by open squares. Closed triangles show volcanic centers.

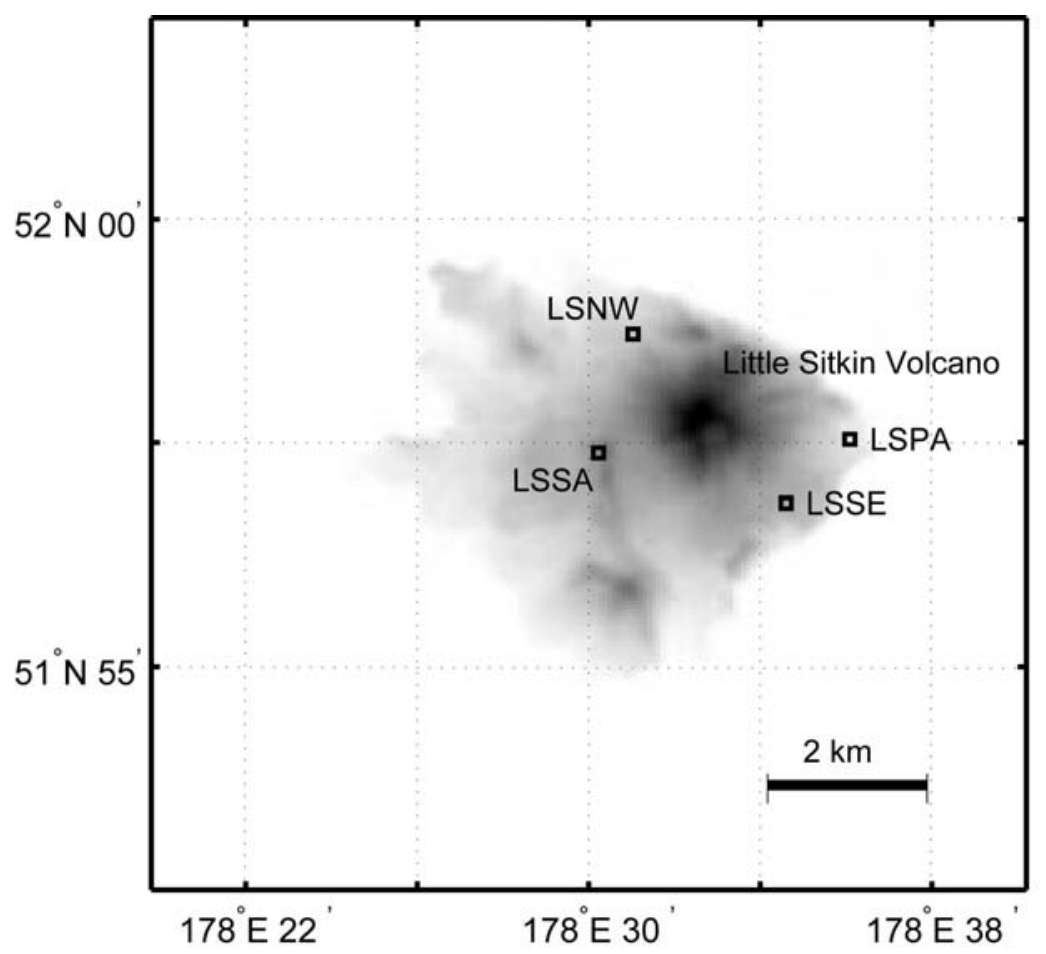

Figure C28. AVO seismograph stations on Little Sitkin Island. Seismograph stations are shown by open squares. Closed triangles show volcanic centers. 
Appendix D: Operational status for AVO stations in 2005. A solid bar indicates periods of time a station was operational based on station use plots and weekly checks. Dashed vertical lines show the beginning/end of each month.

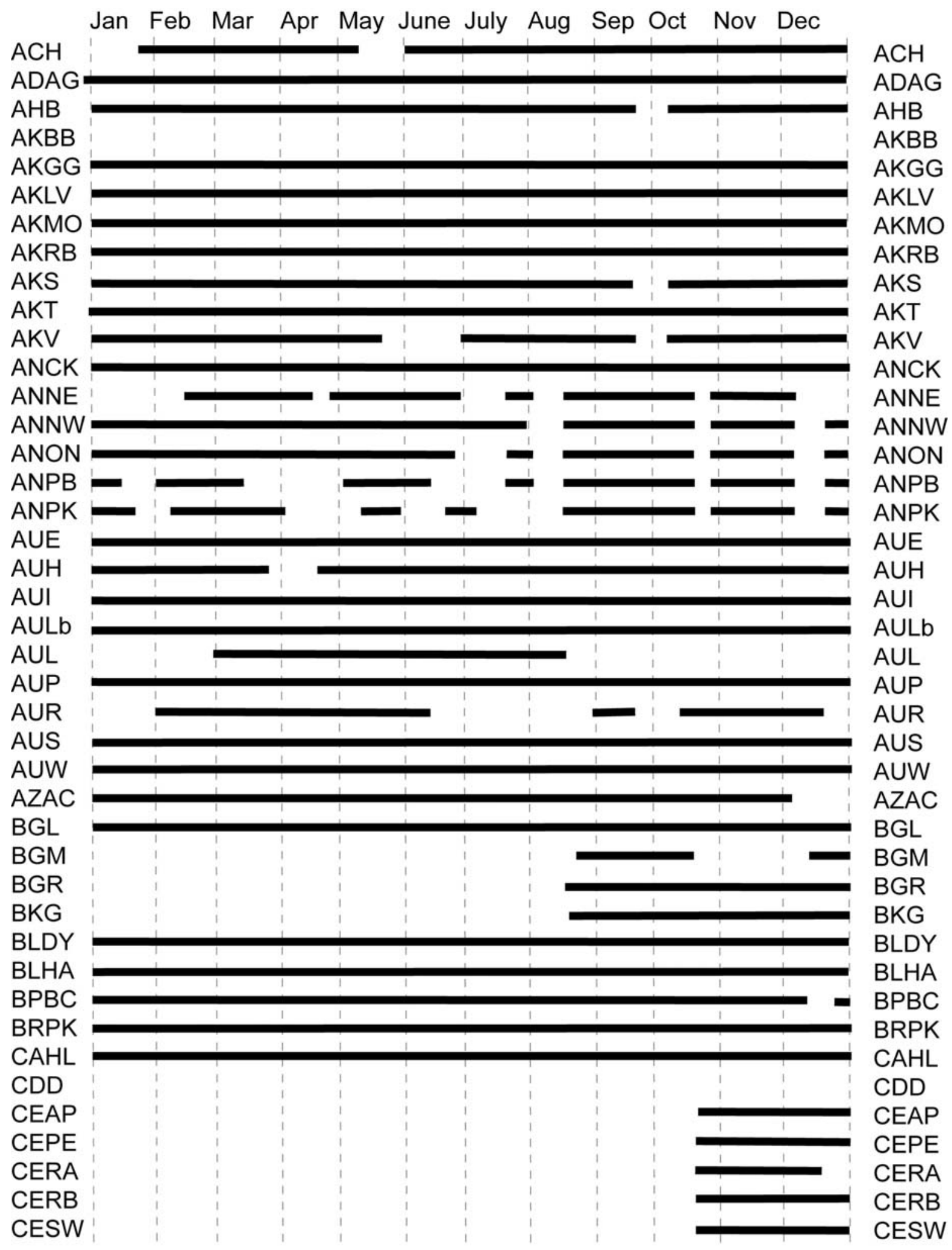


Jan Feb Mar Apr May June July Aug Sep Oct Nov Dec

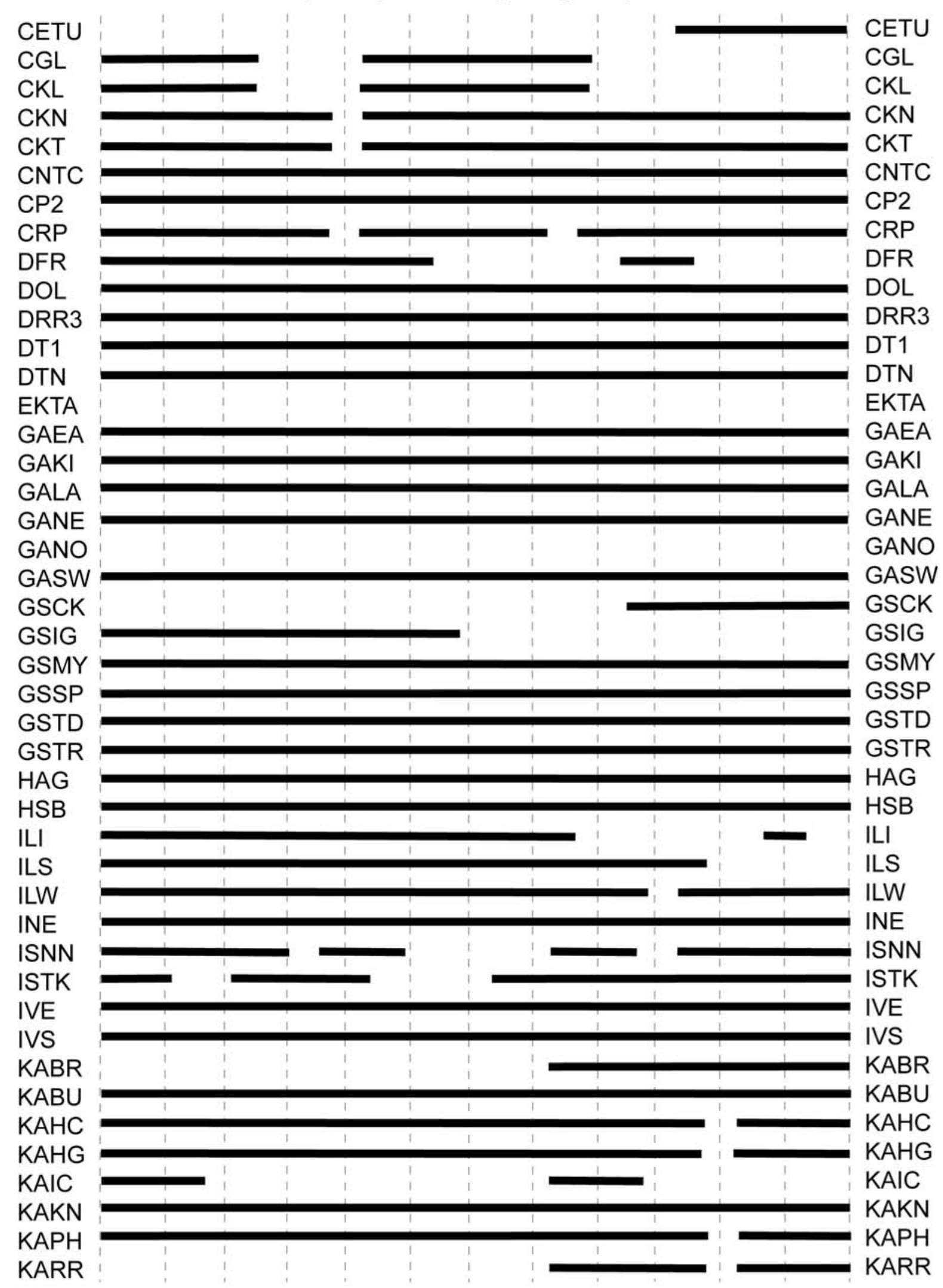


Jan Feb Mar Apr May June July Aug Sep Oct Nov Dec

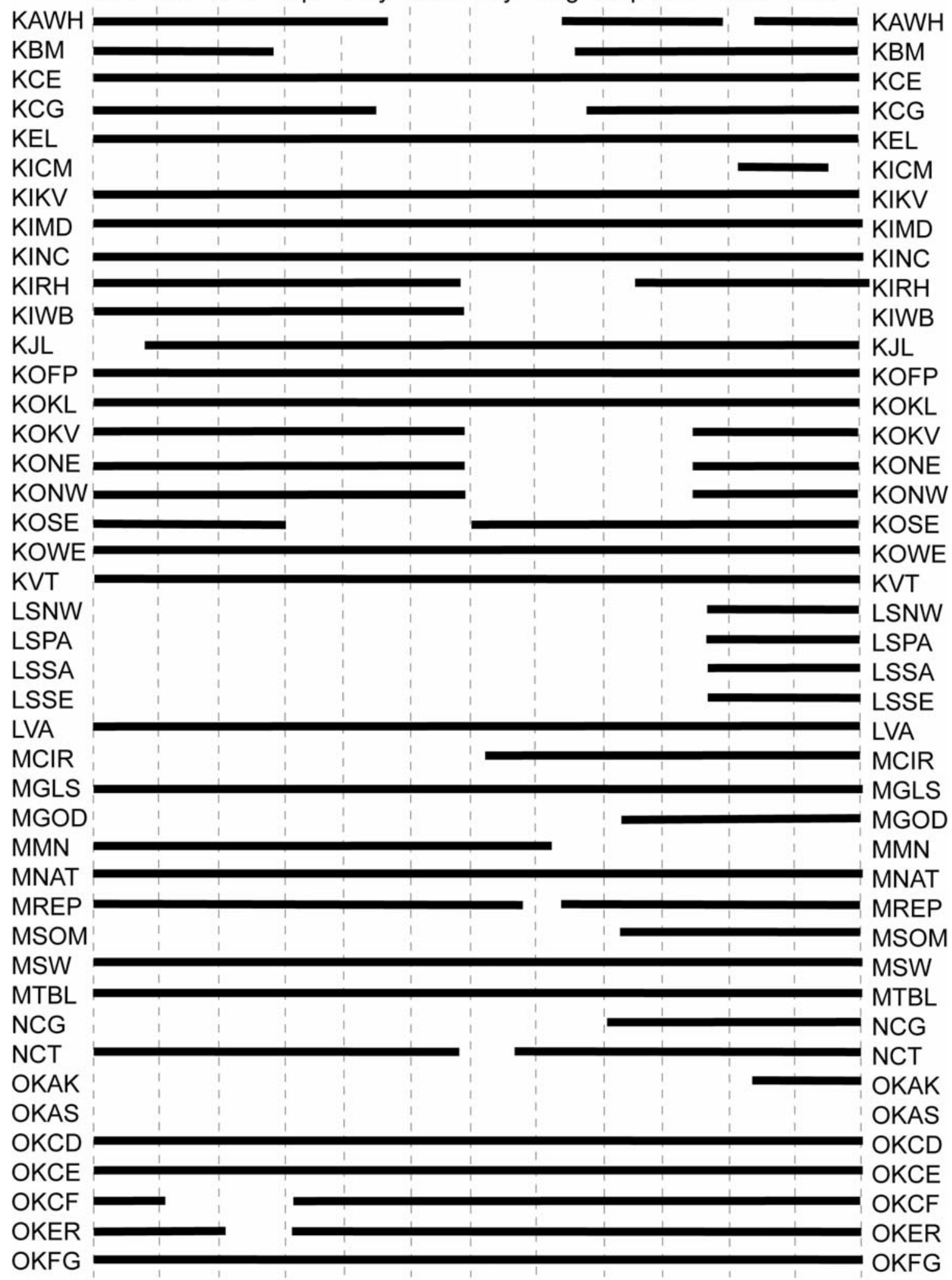




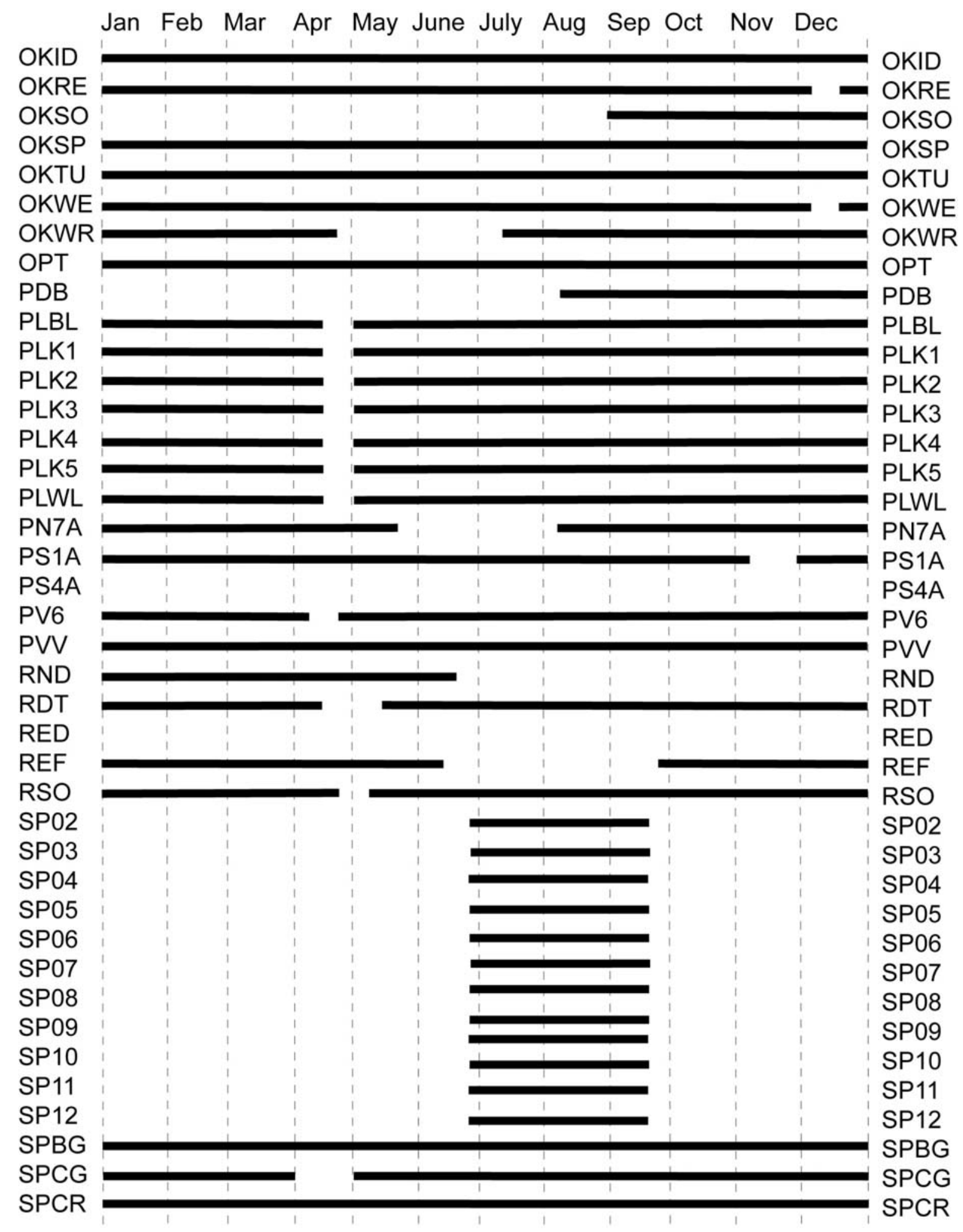




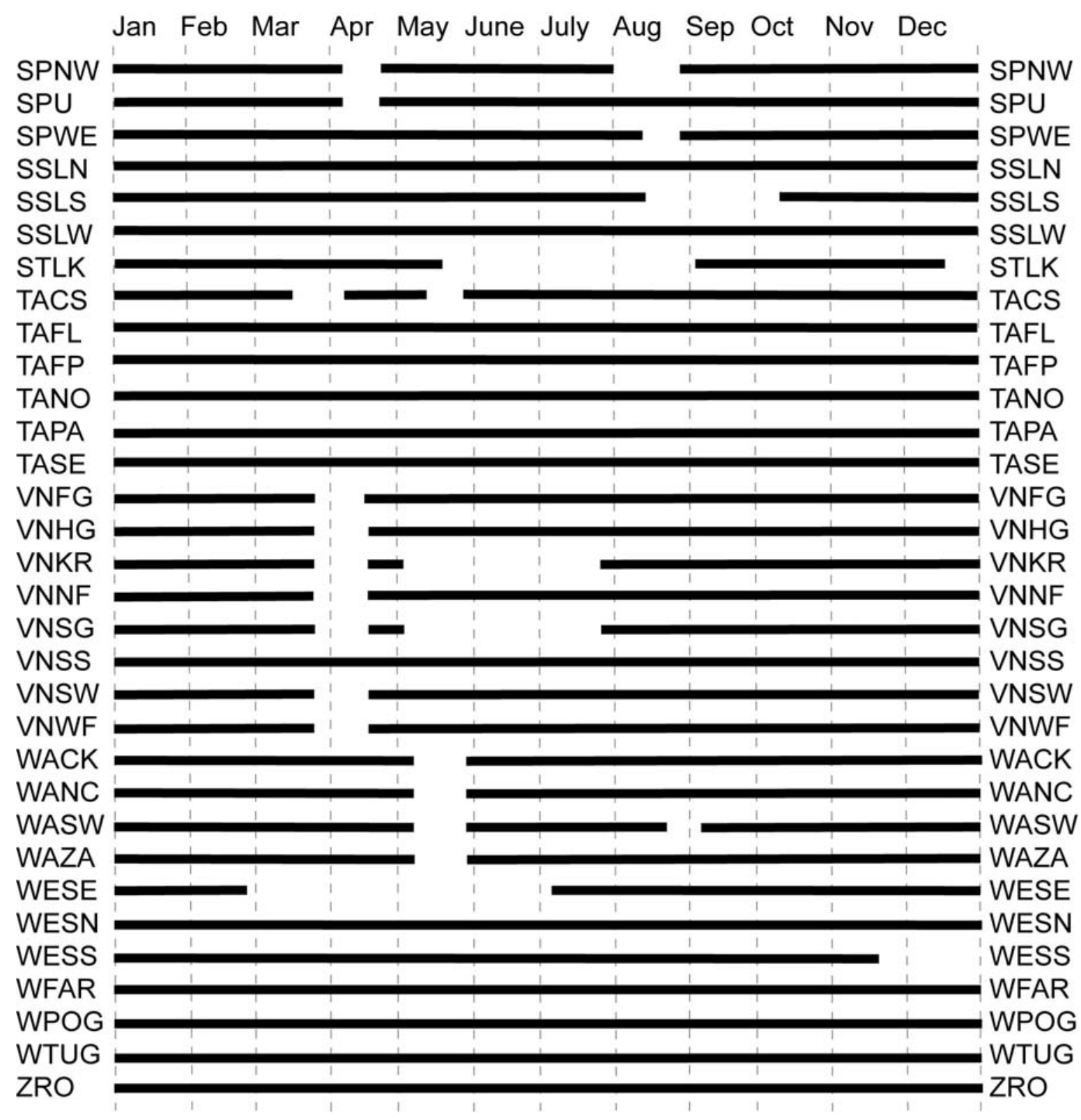


Appendix E: Seismic velocity models used in locating the earthquakes described in this report. Following the name of each velocity model is a list of volcano subnetworks for which the model is used. Depths are referenced to sea level, with negative values reflecting height above sea level.

Cylindrical Model Parameters (Latitude and Longitude are the center of the model)

\begin{tabular}{|c|c|c|c|c|c|}
\hline Velocity Model & Latitude $\left({ }^{\circ} \mathrm{N}\right)$ & Longitude $\left({ }^{\circ} \mathrm{E}\right)$ & $\underline{\text { Radius (km) }}$ & Top (km) & Bottom $(\mathrm{km})$ \\
\hline Spurr & 61.60 & -152.40 & 20 & -3 & 50 \\
\hline Spurr & 61.47 & -152.33 & 20 & -3 & 50 \\
\hline Spurr & 61.33 & -152.25 & 20 & -3 & 50 \\
\hline Spurr & 61.17 & -152.35 & 20 & -3 & 50 \\
\hline Spurr & 61.00 & -152.45 & 20 & -3 & 50 \\
\hline Redoubt & 60.83 & -152.55 & 20 & -3 & 50 \\
\hline Redoubt & 60.66 & -152.66 & 20 & -3 & 50 \\
\hline Redoubt & 60.49 & -152.75 & 20 & -3 & 50 \\
\hline Redoubt & 60.34 & -152.86 & 20 & -3 & 50 \\
\hline Redoubt & 60.19 & -152.98 & 20 & -3 & 50 \\
\hline Redoubt & 59.87 & -153.17 & 20 & -3 & 50 \\
\hline Redoubt & 59.70 & -153.25 & 20 & -3 & 50 \\
\hline Redoubt & 59.53 & -153.34 & 20 & -3 & 50 \\
\hline Iliamna & 60.03 & -153.09 & 20 & -3 & 50 \\
\hline Augustine & 59.36 & -153.42 & 20 & -3 & 50 \\
\hline Katmai & 58.17 & -155.35 & 20 & -3 & 50 \\
\hline Katmai & 58.29 & -154.86 & 20 & -3 & 50 \\
\hline Katmai & 58.35 & -155.09 & 20 & -3 & 50 \\
\hline Katmai & 58.43 & -154.38 & 20 & -3 & 50 \\
\hline Veniaminof & 56.18 & -159.38 & 30 & -3 & 50 \\
\hline Cold Bay & 55.42 & -161.89 & 20 & -3 & 50 \\
\hline Cold Bay & 55.18 & -162.27 & 20 & -3 & 50 \\
\hline Cold Bay & 54.76 & -163.97 & 30 & -3 & 50 \\
\hline Westdahl & 54.52 & -164.65 & 20 & -3 & 50 \\
\hline Akutan & 54.15 & -165.97 & 20 & -3 & 50 \\
\hline Andreanof & 52.08 & -176.13 & 20 & -3 & 50 \\
\hline Andreanof & 51.93 & -176.75 & 20 & -3 & 50 \\
\hline Andreanof & 51.92 & -177.17 & 20 & -3 & 50 \\
\hline Tanaga & 51.89 & -178.15 & 20 & -3 & 50 \\
\hline
\end{tabular}

Regional Velocity Model (for all areas south of $62.5^{\circ} \mathrm{N}$ not covered by a volcano specific model): Aniakchak, Gareloi, Korovin, Little Sitkin, Makushin, Okmok, Peulik, Semisopochnoi, and Wrangell (Fogleman and others, 1993).

\begin{tabular}{c} 
Layer number \\
\hline 1 \\
2 \\
3 \\
4 \\
5 \\
6 \\
7 \\
8 \\
9
\end{tabular}

\begin{tabular}{c}
$\mathrm{Vp}(\mathrm{km} / \mathrm{sec})$ \\
\hline 5.3 \\
5.6 \\
6.2 \\
6.9 \\
7.4 \\
7.7 \\
7.9 \\
8.1 \\
8.3
\end{tabular}

\begin{tabular}{c} 
Top of layer $(\mathrm{km})$ \\
\hline-3.0 \\
4.0 \\
10.0 \\
15.0 \\
20.0 \\
25.0 \\
33.0 \\
47.0 \\
65.0
\end{tabular}

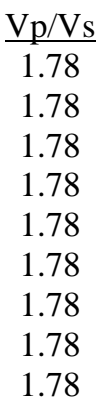


Akutan Velocity Model: Akutan (Power and others, 1996).

Layer number

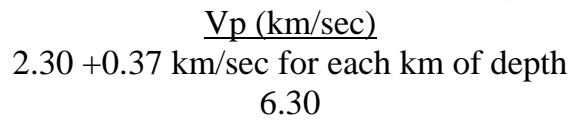

Top of layer $(\mathrm{km})$
-3.0
7.0

$\frac{\mathrm{Vp} / \mathrm{Vs}}{1.80}$

26.30

1.80

Andreanof Velocity model: Great Sitkin, and Kanaga (Toth and Kisslinger, 1984).

Layer number

1

2

3

4

5

6

7

8

9

10

11

12

13

14

15

16

17

18

19

20
$\frac{\mathrm{Vp}(\mathrm{km} / \mathrm{sec})}{3.50}$

3.88

4.25

4.62

5.00

5.50

5.62

5.74

5.86

5.98

6.10

6.60

6.68

6.80

6.92

7.04

7.16

7.28

7.85

8.05
Top of layer $(\mathrm{km})$

$-3.0$

$-2.8$

$-2.6$

$-2.4$

$-2.2$

$-2.0$

$-1.0$

0.0

1.0

2.0

3.0

4.0

5.0

8.0

11.0

14.0

17.0

20.0

23.0

37.0
$\frac{\mathrm{Vp} / \mathrm{Vs}}{1.73}$

1.73

1.73

1.73

1.73

1.73

1.73

1.73

1.73

1.73

1.73

1.73

1.73

1.73

1.73

1.73

1.73

1.73

1.73

1.73

Augustine Velocity Model: Augustine (Power, 1988).

Layer number

1
2
3
4
5
6

\begin{tabular}{c}
$\mathrm{Vp}(\mathrm{km} / \mathrm{sec})$ \\
\hline 2.3 \\
2.6 \\
3.4 \\
5.1 \\
6.3 \\
8.0
\end{tabular}

\begin{tabular}{c} 
Top of layer $(\mathrm{km})$ \\
\hline-3.0 \\
-0.7 \\
0.0 \\
1.0 \\
9.0 \\
44.0
\end{tabular}

Cold Bay Velocity Model: Dutton, Pavlof, and Shishaldin (McNutt and Jacob, 1986).

Layer number

1
2
3
4
5
6
7

1

2

3

4

5

6

7
$\underline{\mathrm{Vp}(\mathrm{km} / \mathrm{sec})}$

3.05

3.44

5.56

6.06

6.72

7.61

7.90
Top of layer $(\mathrm{km})$

$-3.00$

0.00

1.79

3.65

10.18

22.63

38.51

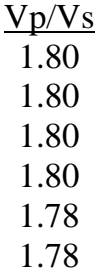


Iliamna Velocity model: Iliamna (Roman and others, 2001).

Layer number

1
2
3
4
5
6

$\mathrm{Vp}(\mathrm{km} / \mathrm{sec})$

4.8

6.1

6.2

6.3

6.4

7.1
Top of layer $(\mathrm{km})$

$-3.0$

$-1.6$

1.7

2.9

3.1

16.5
$\mathrm{Vp} / \mathrm{Vs}$

1.78

1.78

1.78

1.78

1.78

1.78

Katmai Velocity Model: Katmai (Searcy, 2003).

Layer number

1
2
3
4
5
6
7
8
9
10
11
12
13
14
15
16

$\underline{\mathrm{Vp}(\mathrm{km} / \mathrm{sec})}$

5.05

5.10

5.41

5.49

5.65

5.67

5.69

5.76

5.80

6.00

6.04

6.08

6.30

6.73

7.54

7.78 $\underline{\text { Top of layer }(\mathrm{km})}$

$-3.0$

1.0

2.0

3.0

4.0

5.0

6.0

7.0

8.0

9.0

10.0

12.0

15.0

20.0

25.0

33.0
$\underline{\mathrm{Vp} / \mathrm{Vs}}$

1.78

1.78

1.78

1.78

1.78

1.78

1.78

1.78

1.78

1.78

1.78

1.78

1.78

1.78

1.78

1.78

Redoubt Velocity Model: Redoubt (Lahr and others, 1994) .

Layer number

1

2

3

4
$\underline{\mathrm{Vp}(\mathrm{km} / \mathrm{sec})}$

2.90

5.10

6.40

7.00
Top of layer $(\mathrm{km})$

$-3.0$

$-1.7$

1.5

17.0
$\underline{\mathrm{Vp} / \mathrm{Vs}}$

1.80

1.80

1.72

1.78

Spurr Velocity Model: Spurr (Jolly and others, 1994).

Layer number

1

2

3

4
$\mathrm{Vp}(\mathrm{km} / \mathrm{sec})$

5.1

5.5

6.3

7.2
Top of layer $(\mathrm{km})$

$-3.00$

$-2.00$

5.25

27.25
$\underline{\mathrm{Vp} / \mathrm{Vs}}$

1.81

1.81

1.74

1.78

Tanaga Velocity Model: Tanaga (Power, personal communication, 2005) .

Layer number

1
2
3
4
5
6
7
8

1

2

3

4

5
6

7

8
$\underline{\mathrm{Vp}(\mathrm{km} / \mathrm{sec})}$

4.0

4.5

5.0

5.6

6.9

7.2

7.8

8.1
Top of layer (km)

$-3.0$

$-1.2$

0.0

4.0

10.0

15.0

20.0

33.0
$\frac{\mathrm{Vp} / \mathrm{Vs}}{1.78}$

1.78

1.78

1.78

1.78

1.78

1.78

1.78 
Veniaminof Velocity Model: Veniaminof (Sánchez, 2005) .

\begin{tabular}{cccc} 
Layer number & Vp $(\mathrm{km} / \mathrm{sec})$ & Top of layer $(\mathrm{km})$ & Vp/Vs \\
\cline { 2 - 4 } 1 & 4.82 & -3.0 & 1.73 \\
2 & 5.23 & 4.0 & 1.88 \\
3 & 5.23 & 10.0 & 1.38 \\
4 & 6.49 & 15.0 & 1.65 \\
5 & 6.52 & 20.0 & 1.51 \\
6 & 8.18 & 25.0 & 1.89 \\
7 & 8.21 & 33.0 & 1.90 \\
8 & 8.21 & 47.0 & 1.80 \\
9 & 8.30 & 65.0 & 1.78
\end{tabular}

Westdahl Velocity Model: Westdahl (Dixon and others, 2005).

Layer number

1

2

3

4

5

6

7

8
$\mathrm{Vp}(\mathrm{km} / \mathrm{sec})$

3.03

3.18

5.03

5.70

6.30

6.82

7.17

8.16
Top of layer $(\mathrm{km})$

$-3.0$

0.0

2.0

8.0

10.0

16.0

26.0

38.0
$\mathrm{Vp} / \mathrm{Vs}$

1.71

1.71

1.71

1.71

1.71

1.71

1.71

1.71 
Appendix F: Maps showing the location of volcanic zones modeled using multiple cylinders. Volcanic centers, modeled by a single cylinder, are not shown.

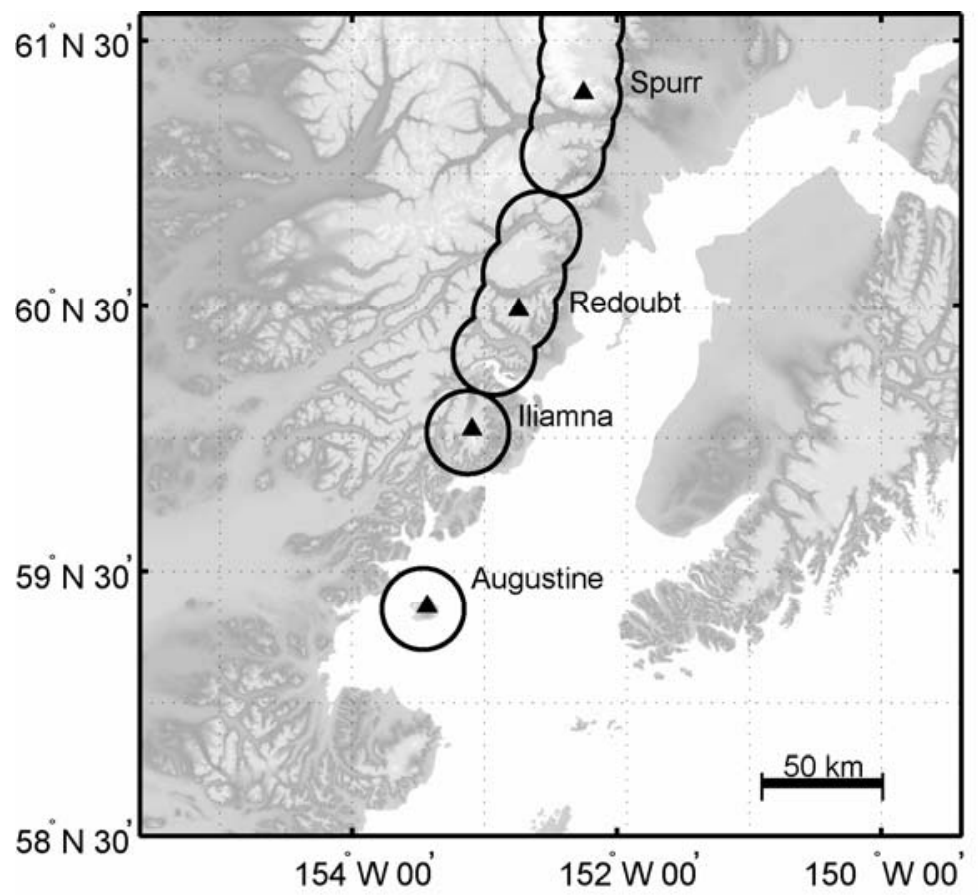

Figure F1. Volcanic zones for the Cook Inlet Volcanoes. Five overlapping cylinders model the Spurr volcanic zone. Four overlapping cylinders model the Redoubt volcanic zone. Single cylinders model the Iliamna and Augustine volcanic zones.

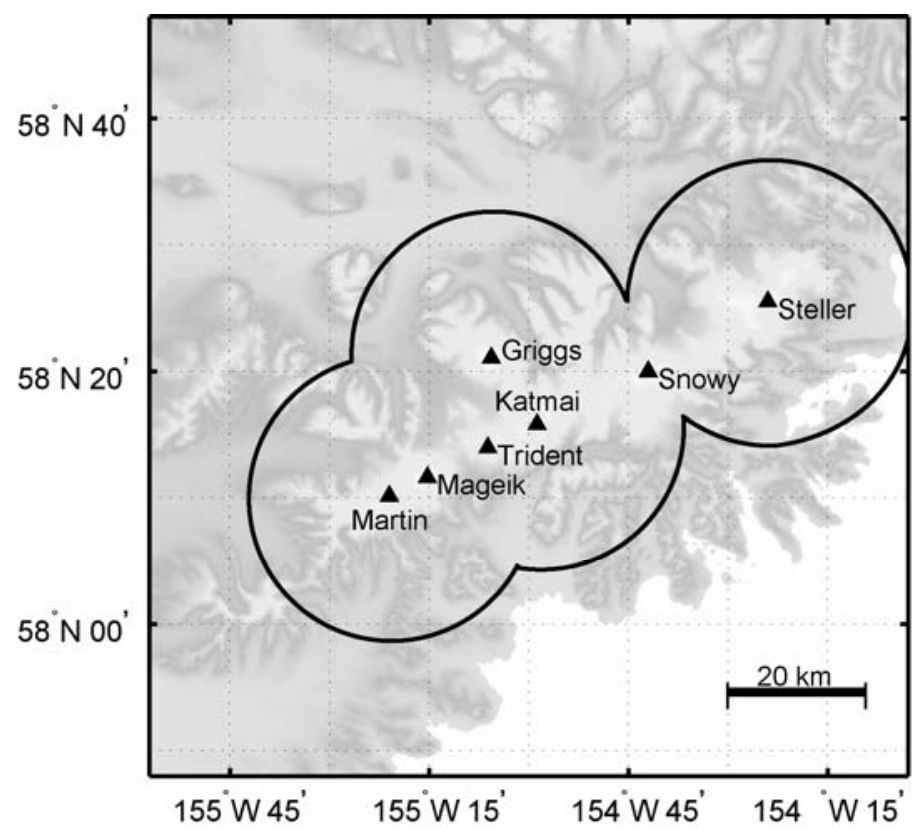

Figure F2. Volcanic zone for the Katmai volcanic cluster. The volcanic zone is modeled using four cylinders centered on Mount Martin, Mount Katmai, Mount Griggs and Mount Steller. 


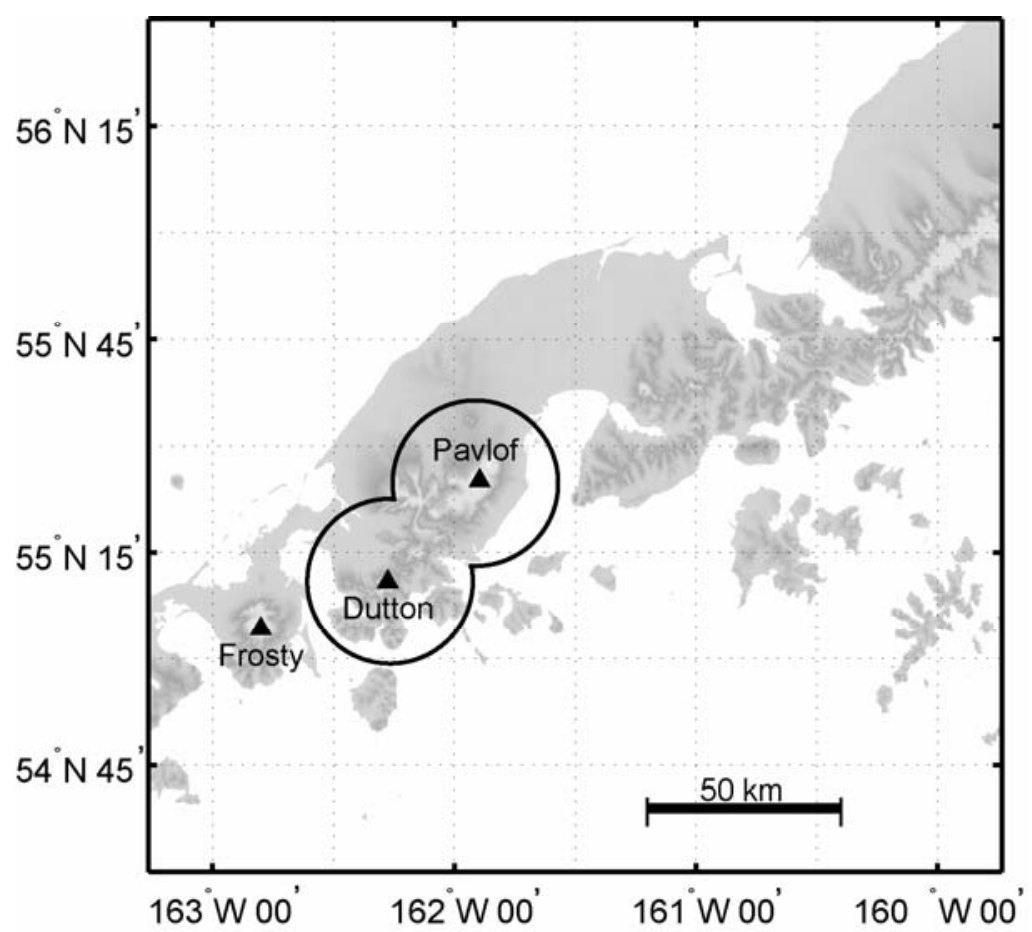

Figure F3. Volcanic zones for Mount Veniaminof Dutton. The volcanic zone is modeled using a single cylinder.

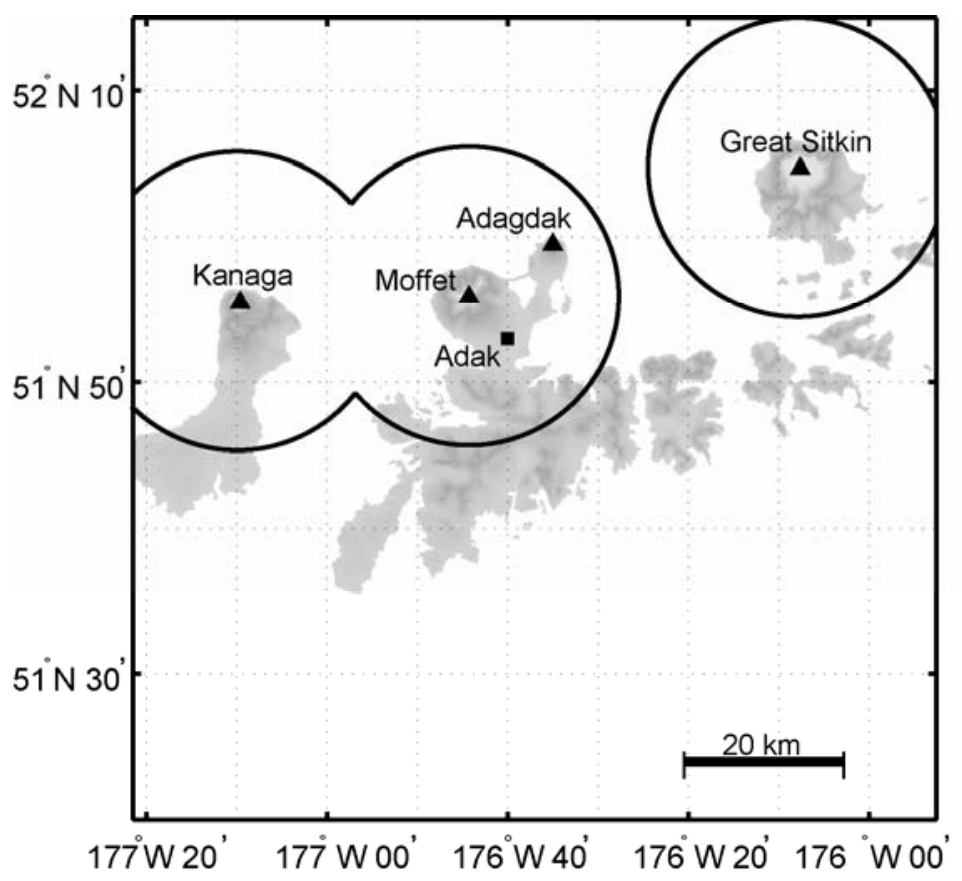

Figure F4. Volcanic zones in the Adak region. The volcanic zones are modeled using cylinders centered on Kanaga Volcano, Mount Moffet, and Great Sitkin Volcano. 


\section{Appendix G: Previous AVO Earthquake Catalogs.}

1989-90: Power, J. A., G. D. March, J. C. Lahr, A. D. Jolly, and G. R. Cruse (1993).

Catalog of earthquake hypocenters at Redoubt Volcano and Mount Spurr, Alaska:

October 12, 1989-December 31, 1990, U.S. Geol. Surv. Open-File Rept., 93-685-

A, $57 \mathrm{p}$.

1991-93: Jolly, A. D., J. A. Power, S. D. Stihler, L. N. Rao, G. Davidson, J. Paskievitch, S. Estes, J. C. Lahr (1996). Catalog of earthquake hypocenters for Augustine, Redoubt, Iliamna, and Mount Spurr Volcanoes, Alaska: January 1, 1991 December 31, 1993, U.S. Geol. Surv. Open-File Rept. 96-70, 90 p.

1994-99: Jolly, A. D., S. D. Stihler, J. A. Power, J. C. Lahr, J. Paskievitch, G., Tytgat, S. Estes, A. B. Lockhart, S. C. Moran, S. R. McNutt, and W. R. Hammond (2001). Catalog of earthquake hypocenters at Alaskan Volcanoes: January 1, 1994 December 31, 1999, U.S. Geol. Surv. Open-File Rept. t 01-189, 202 p.

2000-01: Dixon, J. P, S. D. Stihler, J. A. Power, G. Tytgat, S. Estes, S. C. Moran, J. Paskievitch, and S. R. McNutt (2002). Catalog of Earthquake Hypocenters at Alaska Volcanoes: January 1, 2000 - December 31, 2001, U.S. Geol. Surv. OpenFile Rept. 02-342, 56 p.

2002: Dixon, J. P., S. D. Stihler, J. A. Power, G. Tytgat, S. C. Moran, J. J. Sánchez, S. Estes, S. R. McNutt and J. Paskievitch (2003). Catalog of Earthquake Hypocenters at Alaska Volcanoes: January 1 - December 31, 2002, U.S. Geol. Surv. Open-File Rept. 03-267, 58 p.

2003: Dixon, J. P., S. D. Stihler, J. A. Power, G. Tytgat, S. C. Moran, J. J. Sánchez, S. Estes, S. R. McNutt, and J. Paskievitch (2004). Catalog of Earthquake Hypocenters at Alaska Volcanoes: January 1 - December 31, 2003, U.S. Geol. Surv. Open-File Rept. 2004-1234, 59 p.

2004: Dixon, J. P., S. D. Stihler, J. A. Power, G. Tytgat, S. Estes, S. Prejean, J. J. Sánchez, R. Sanches, S. R. McNutt, and J. Paskievitch (2005). Catalog of Earthquake Hypocenters at Alaskan Volcanoes: January 1 through December 31, 2004, U.S. Geol. Surv. Open-File Rept. 2005-1312, 74 p. 


\section{Appendix H: Selected AVO papers published in 2005}

De Angelis, S. and S. R. McNutt (2005). Degassing and hydrothermal activity at Mt. Spurr, Alaska during the summer of 2004 inferred from the complex frequencies of long-period events, Geophys. Res. Lett., 32, L12312, Doi: 10.1029/2005GL022618.

Lu, Z., C. Wicks, O. Kwoun, J. A. Power, D. Dzurisin (2005). Surface deformation associated with the March 1996 earthquake swarm at Akutan Island, Alaska, revealed by Cband ERS and L-band radar interferometry, Can. J. Remote Sensing, 31, 7-20.

McNutt, S. R. (2005). A Review of Volcanic Seismology. Ann. Rev. Earth Planet. Sci., 33, 461-491 doi: 10.1146/annurev.earth.33.092203.122459.

West, M., J. J. Sánchez, and S. R. McNutt (2005). Periodically-triggered seismicity at Mt. Wrangell volcano following the Sumatra-Andaman Islands earthquake, Science, 308, 11441146. 